2. Io: (Receiving Organization)

Distribution

5. Proj./Prog./Dept./Div.:

Tank 241-T-109/Waste

Management/DAI/TWRS

Technical Basis

8. originator Remarks:

This document is being released into the supporting document system for retrievability purposes.

11. Receiver Remarks: 11A. Design Baseline Document? [] Yes $[X]$ No For release.
3. From: (originating Organization)

Data Assessment and Interpretation

6. Design Authority/ Design Agent/Cog. Engr : :

Todd M. Brown
4. Related EDT NO.:

$\mathrm{N} / \mathrm{A}$

7. Purchase Order No.:

N/A

9. Equip./Component No.: $\mathrm{N} / \mathrm{A}$

10. System/Bldg./Facility: 241-T-109

12. Major Assm. Dwg. No.: N/A

13. Permit/Permit Application No.: N/A

14. Required Response Date: 09/05/96

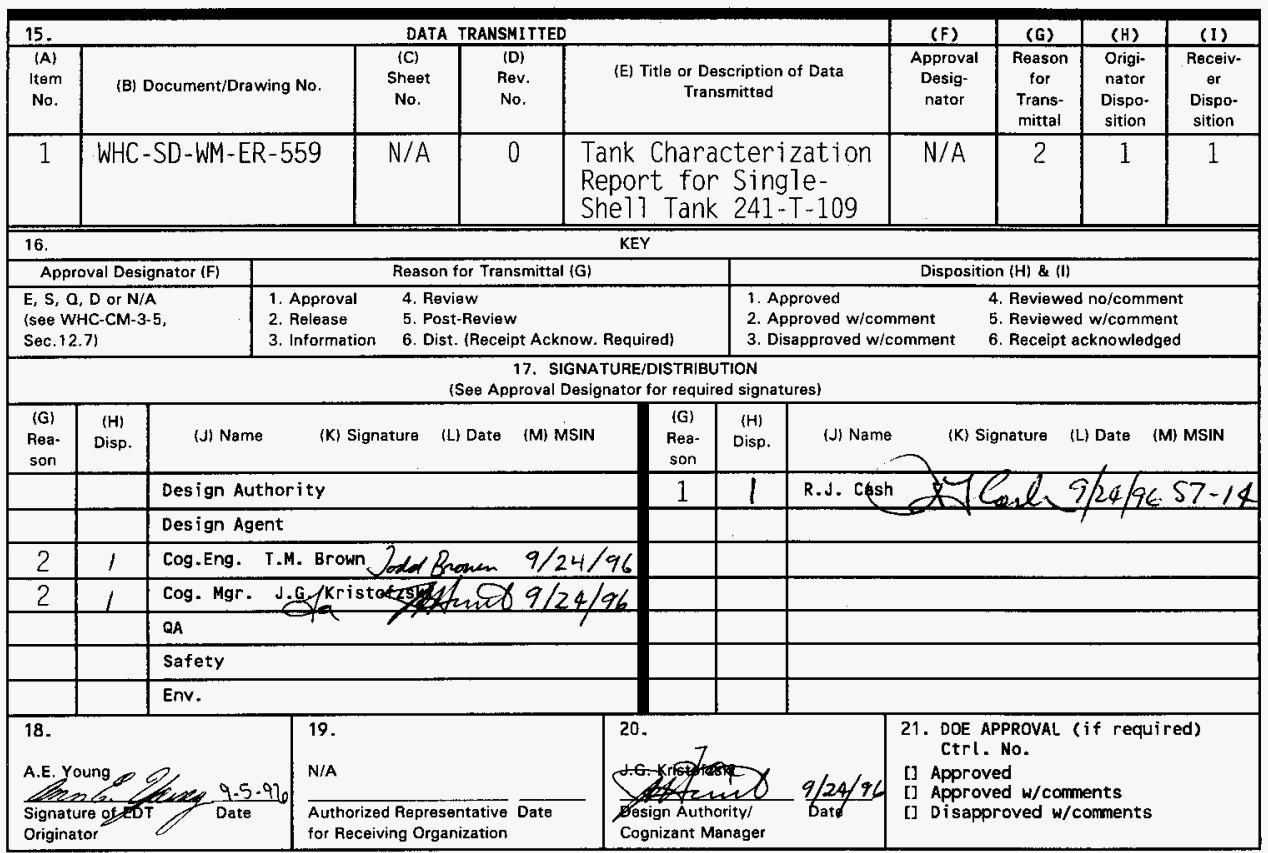

BD-7400-172-2 (05/96) GEF097 


\section{Tank Characterization Report for Single-Shell Tank 241-T-109}

Todd M. Brown

Westinghouse Hanford Company. Richland. WA 99352

U.S. Department of Energy Contract DE-AC06-87RL10930

EDT/ECN: EDT-617544 UC: 2070

Org Code: $79400 \quad$ Charge Code: N4G4D

B\&R Code: EW 3120074 Tota1 Pages: //4

Key Words: Tank Characterization Report, TCR, Single-Shell Tank,

Single-She11, SST, Tank 241-T-109, Tank T-109, T-109, T Farm

Abstract: This document summarizes the information on the historical uses, present status, and the sampling and analysis results of waste stored in Tank 241-T-109. This report supports the requirements of TriParty Agreement Mi lestone M-44-09.

TRADEMARK DISCLAIMER. Reference herein to any specific commercial product, process, or service by trade name, trademark, manufacturer, or otherwise, does not necessarily constitute or imply its endorsement, recommendation, or favoring by the United States Government or any agency thereof or its contractors or subcontractors.

Printed in the United States of America. To obtain copies of this document, contact: HHC/BCS Document Control Services, P.O. Box 1970, Mailstop H6-08, Richland WA 99352, Phone (509) 372-2420; Fax (509) 376-4989.
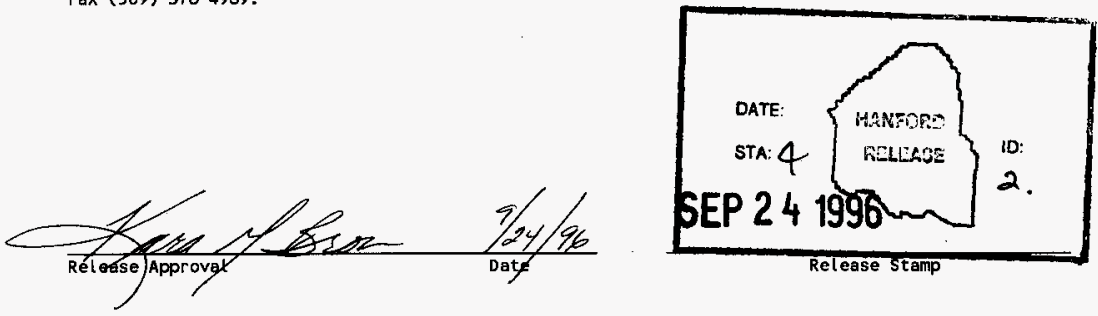

Approved for Public Release 


\title{
Tank Characterization Report for Single-Shell Tank 241-T-109
}

\author{
T. M. Brown \\ L. M. Sasaki \\ R. D. Cromar \\ Westinghouse Hanford Company \\ N. G. Colton \\ Pacific Northwest National Laboratory \\ J. L. Stroup \\ ICF Kaiser Engineers Hanford \\ J. D. Franklin \\ Los Alamos Technical Associates \\ L. J. Fergestrom \\ Technical Resources International, Inc. \\ Date Published \\ September 1996
}

Prepared for the U.S. Department of Energy

Assistant Secretary for Environmental Management

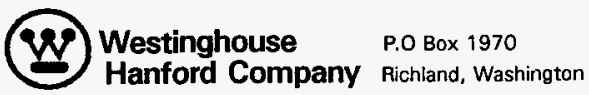

Management and Operations Contractor for the

U.S. Department of Energy under Contract DE-AC06-87RL10930

Approved for public release; distribution is unlimited 


\section{CONTENTS}

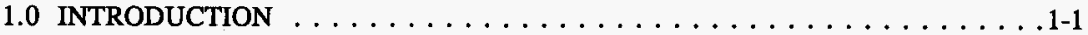

1.1 SCOPE . . . . . . . . . . . . . . . . . . .

1.2 TANK BACKGROUND $\ldots \ldots \ldots \ldots \ldots \ldots \ldots \ldots \ldots \ldots \ldots \ldots \ldots$

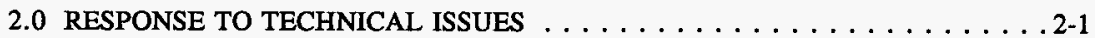

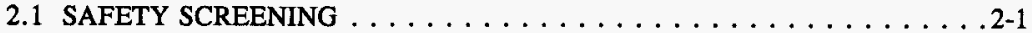

2.1.1 Exothermic Conditions (Energetics) $\ldots \ldots \ldots \ldots \ldots \ldots \ldots . \ldots \ldots$

2.1 .2 Flammable Gas . . . . . . . . . . . . . . . 2-2

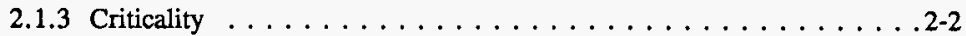

2.2 HISTORICAL EVALUATION $\ldots \ldots \ldots \ldots \ldots \ldots \ldots \ldots \ldots \ldots \ldots \ldots \ldots .2-2$

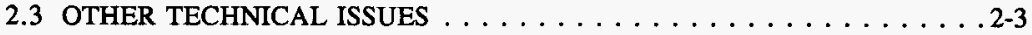

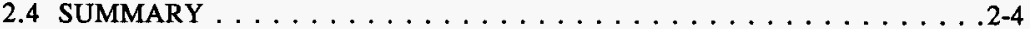

3.0 BEST-BASIS INVENTORY ESTIMATE $\ldots \ldots \ldots \ldots \ldots \ldots \ldots$ 3-1

4.0 RECOMMENDATIONS $\ldots \ldots \ldots \ldots \ldots \ldots \ldots \ldots \ldots \ldots \ldots \ldots \ldots \ldots$ 4-1

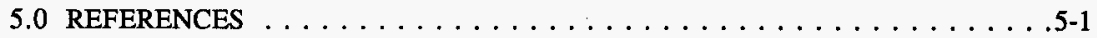

\section{APPENDICES}

APPENDIX A: HISTORICAL TANK INFORMATION $\ldots \ldots \ldots \ldots \ldots \ldots \ldots$ A-1

A1.0 CURRENT TANK STATUS $\ldots \ldots \ldots \ldots \ldots \ldots \ldots \ldots \ldots \ldots$

A2.0 TANK DESIGN AND BACKGROUND $\ldots \ldots \ldots \ldots \ldots \ldots \ldots$ A-4

A3.0 PROCESS KNOWLEDGE . . . . . . . . . . . . . . . . A A-9

A3.1 WASTE TRANSFER HISTORY . . . . . . . . . . . . A A-9

A3.2 HISTORICAL ESTIMATION OF TANK CONTENTS . . . . . . . . . A-10

A4.0 SURVEILLANCE DATA $\ldots \ldots \ldots \ldots \ldots \ldots \ldots \ldots \ldots \ldots \ldots$ A-14

A4.1 SURFACE-LEVEL READINGS $\ldots \ldots \ldots \ldots \ldots \ldots \ldots \ldots$ A-14

A4.2 INTERNAL TANK TEMPERATURES $\ldots \ldots \ldots \ldots \ldots \ldots \ldots \ldots \ldots$ A-14

A4.3 TANK $241-\mathrm{T}-109$ PHOTOGRAPHS . . . . . . . . . . . . . A-15

A5.0 APPENDIX A REFERENCES $\ldots \ldots \ldots \ldots \ldots \ldots \ldots \ldots \ldots \ldots$ A-18 


\section{CONTENTS (Continued)}

APPENDIX B: SAMPLING OF TANK $241-T-109 \ldots \ldots \ldots \ldots \ldots$ B-1

B1.0 TANK SAMPLING OVERVIEW $\ldots \ldots \ldots \ldots \ldots \ldots \ldots \ldots$ B-3

B1.1 DESCRIPTION OF SAMPLING EVENT $\ldots \ldots \ldots \ldots \ldots \ldots$ B-3

B1.2 SAMPLE HANDLING $\ldots \ldots \ldots \ldots \ldots \ldots \ldots \ldots$ B-5

B1.3 SAMPLE ANALYSIS $\ldots \ldots \ldots \ldots \ldots \ldots \ldots \ldots$ B-5

B1.4 DESCRIPTION OF HISTORICAL SAMPLING EVENT $\ldots \ldots \ldots \ldots$ B-6

B2.0 ANALYTICAL RESULTS $\ldots \ldots \ldots \ldots \ldots \ldots \ldots \ldots \ldots \ldots$ B-7

B2.1 OVERVIEW $\ldots \ldots \ldots \ldots \ldots \ldots \ldots \ldots \ldots \ldots \ldots$ B-7

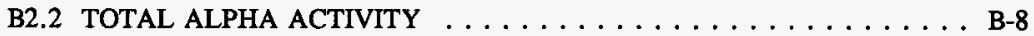

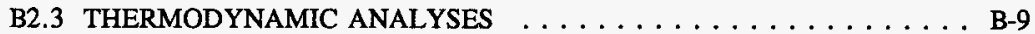

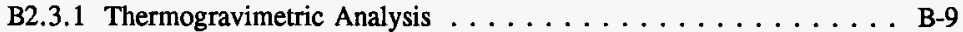

B2.3.2 Differential Scanning Calorimetry . . . . . . . . . B-10

B2.4 INORGANIC ANALYSES . . . . . . . . . . . . . B-11

B2.4.1 Inductively Coupled Plasma $\ldots \ldots \ldots \ldots \ldots \ldots \ldots$ B-12

B2.4.2 Ion Chromatography . . . . . . . . . . . . . . B-24

B2.5 VAPOR PHASE MEASUREMENT . . . . . . . . . . . . B-27

B2.6 HISTORICAL SAMPLE RESULTS $\ldots \ldots \ldots \ldots \ldots \ldots \ldots \ldots$. . . . . . . .

B3.0 ASSESSMENT OF CHARACTERIZATION RESULTS . . . . . . . . . . . B-29

B3.1 FIELD OBSERVATIONS $\ldots \ldots \ldots \ldots \ldots \ldots \ldots \ldots \ldots \ldots$. . . . . . . . . . . . . .

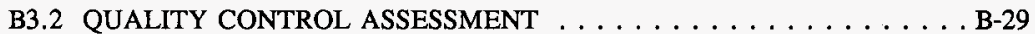

B3.3 DATA CONSISTENCY CHECKS . . . . . . . . . . B-30

B3.3.1 Comparison of Results from

Different Analytical Methods . . . . . . . . . . . . . . . . B-30

B3.3.2 Mass and Charge Balance . . . . . . . . . . . . . B-31

B3.4 CALCULATION OF ANALYTICAL BASED MEANS AND

INVENTORY $\ldots \ldots \ldots \ldots \ldots \ldots \ldots \ldots \ldots \ldots \ldots \ldots \ldots$

B4.0 APPENDIX B REFERENCES $\ldots \ldots \ldots \ldots \ldots \ldots \ldots \ldots \ldots \ldots$. . . . . . . .

APPENDIX C: STATISTICAL ANALYSIS FOR ISSUE RESOLUTION $\ldots \ldots \ldots$ C-1

C1.0 STATISTICS FOR SAFETY SCREENING DQO $\ldots \ldots \ldots \ldots \ldots \ldots$ C-3

C2.0 GATEWAY ANALYSIS FOR HISTORICAL MODEL DQO . . . . . . C-4

C3.0 APPENDIX C REFERENCES $\ldots \ldots \ldots \ldots \ldots \ldots \ldots \ldots \ldots$ C-6 


\section{CONTENTS (Continued)}

APPENDIX D: EVALUATION TO ESTABLISH BEST-BASIS INVENTORY FOR

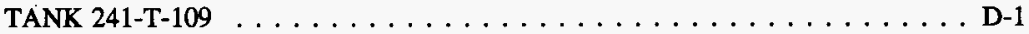

D1.0 CHEMICAL INFORMATION SOURCES $\ldots \ldots \ldots \ldots \ldots \ldots$ D-3

D2.0 COMPARISON OF COMPONENT INVENTORY VALUES $\ldots \ldots \ldots \ldots$ D-3

D3.0 COMPONENT INVENTORY EVALUATION $\ldots \ldots \ldots \ldots \ldots \ldots$ D-7

D4.0 DEFINE THE BEST-BASIS AND ESTABLISH COMPONENT

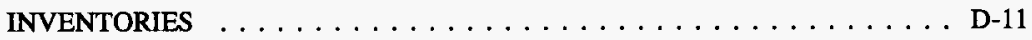

D5.0 APPENDIX D REFERENCES $\ldots \ldots \ldots \ldots \ldots \ldots \ldots \ldots \ldots \ldots$ D-15

APPENDIX E: BIBLIOGRAPHY FOR TANK $241-T-109 \ldots \ldots \ldots \ldots \ldots$ E-1

\section{LIST OF FIGURES}

A2-1 Riser Configuration for Tank $241-\mathrm{T}-109 \ldots \ldots \ldots \ldots \ldots$ A-6 . . . . . .

A2-2 Tank 241-T-109 Cross Section and Schematic . . . . . . . . . A-8

A3-1 Tank Layer Model $\ldots \ldots \ldots \ldots \ldots \ldots \ldots \ldots \ldots$ A-11

A4-1 Tank 241-T-109 Level History . . . . . . . . . . . . . . . . . A-16

A4-2 Tank 241-T-109 High Temperature Plot . . . . . . . . . . . . . A-17 


\section{LIST OF TABLES}

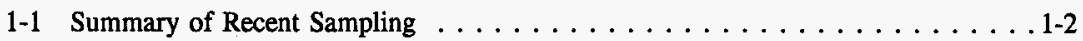

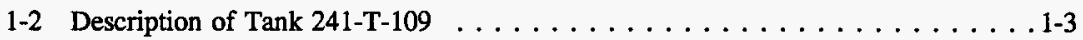

2-1 Summary of Safety Screening and Historical Evaluation Results $\ldots \ldots \ldots 2-4$

3-1 Best-Basis Inventory Estimate for Tank 241-T-109 (Percent Nonradioactive Chemical Species) $\ldots \ldots \ldots \ldots \ldots \ldots \ldots \ldots \ldots \ldots \ldots \ldots . . \ldots \ldots$

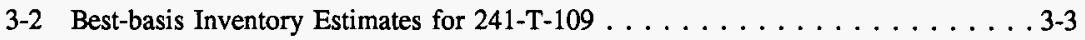

4-1 Acceptance of Tank 241-T-109 Sampling and Analysis . . . . . . . . . . . 4-1

4-2 Acceptance of Evaluation of Characterization Data and Information for Tank $241-\mathrm{T}-109 \ldots \ldots \ldots \ldots \ldots \ldots .2 \ldots \ldots .2$

A1-1 Tank Contents Status Summary (Hanlon 1996) . . . . . . . . . . . A-4

A2-1 Tank 241-T-109 Risers . . . . . . . . . . . . . . A A-7

A3-1 Tank 241-T-109 Major Transfers $\ldots \ldots \ldots \ldots \ldots \ldots \ldots \ldots \ldots$ A-10 . . . . . . . . .

A3-2 Historical Tank Inventory Estimate $\ldots \ldots \ldots \ldots \ldots \ldots \ldots \ldots$ A . . . . . . .

B1-1 Integrated Data Quality Objective Requirements for Tank 241-T-109 . . . . . B-4

B1-2 Tank 241-T-109 Subsampling Scheme and Sample Description . . . . . . . B-5

B1-3 Tank 241-T-109 Sample Analysis Summary . . . . . . . . . . . . . . B B-7

B2-1 Analytical Presentation Tables $\ldots \ldots \ldots \ldots \ldots \ldots \ldots \ldots$ B-8

B2-2 Tank 241-T-109 Total Alpha Activity . . . . . . . . . . . . B-9

B2-3 Percent Water by TGA and Gravimetric Analysis . . . . . . . . . B-10

B2-4 Differential Scanning Calorimetry $\ldots \ldots \ldots \ldots \ldots \ldots \ldots \ldots$ B-11

B2-5 Tank 241-T-109 Analytical Results: Aluminum . . . . . . . . . . . . . B-12

B2-6 Tank 241-T-109 Analytical Results: Antimony . . . . . . . . . . . . . . B-12 


\section{LIST OF TABLES (Continued)}

B2-7 Tank 241-T-109 Analytical Results: Arsenic . . . . . . . . . . . . . B-13

B2-8 Tank 241-T-109 Analytical Results: Barium . . . . . . . . . . . . B-13

B2-9 Tank 241-T-109 Analytical Results: Beryllium . . . . . . . . . . . . . B-13

B2-10 Tank 241-T-109 Analytical Results: Bismuth . . . . . . . . . . . . . . B-14

B2-11 Tank 241-T-109 Analytical Results: Boron . . . . . . . . . . . . . . . . B-14

B2-12 Tank 241-T-109 Analytical Results: Cadmium . . . . . . . . . . . . B-14

B2-13 Tank 241-T-109 Analytical Results: Calcium . . . . . . . . . . . . . . B-15

B2-14 Tank 241-T-109 Analytical Results: Cerium . . . . . . . . . . . . B-15

B2-15 Tank 241-T-109 Analytical Results: Chromium . . . . . . . . . . . . . B-15

B2-16 Tank 241-T-109 Analytical Results: Cobalt $\ldots \ldots \ldots \ldots \ldots \ldots$. . . . . . . . .

B2-17 Tank 241-T-109 Analytical Results: Copper . . . . . . . . . . . . . . . B-16

B2-18 Tank 241-T-109 Analytical Results: Iron . . . . . . . . . . . . . B-16

B2-19 Tank 241-T-109 Analytical Results: Lanthanum . . . . . . . . . . . . . B-17

B2-20 Tank 241-T-109 Analytical Results: Lead $\ldots \ldots \ldots \ldots \ldots$. . . . . . . . . .

B2-21 Tank 241-T-109 Analytical Results: Lithium . . . . . . . . . . . . . B-17

B2-22 Tank 241-T-109 Analytical Results: Magnesium . . . . . . . . . . . B-18

B2-23 Tank 241-T-109 Analytical Results: Manganese . . . . . . . . . . . . . . B-18

B2-24 Tank 241-T-109 Analytical Results: Molybdenum . . . . . . . . . . . . B B-18

B2-25 Tank 241-T-109 Analytical Results: Neodymium . . . . . . . . . . . . . . B-19

B2-26 Tank 241-T-109 Analytical Results: Nickel . . . . . . . . . . . . . . . B-19

B2-27 Tank 241-T-109 Analytical Results: Phosphorus . . . . . . . . . . . . . . B-19 


\section{LIST OF TABLES (Continued)}

B2-28 Tank 241-T-109 Analytical Results: Potassium . . . . . . . . . . . . B-20

B2-29 Tank 241-T-109 Analytical Results: Samarium . . . . . . . . . . . . . B-20

B2-30 Tank 241-T-109 Analytical Results: Selenium . . . . . . . . . . . . . B-20

B2-31 Tank 241-T-109 Analytical Results: Silicon . . . . . . . . . . . . . B-21

B2-32 Tank 241-T-109 Analytical Results: Silver . . . . . . . . . . . . . . B-21

B2-33 Tank 241-T-109 Analytical Results: Sodium . . . . . . . . . . . . B B-21

B2-34 Tank 241-T-109 Analytical Results: Sulfur . . . . . . . . . . . . . . . B-22

B2-35 Tank 241-T-109 Analytical Results: Strontium . . . . . . . . . . B-22

B2-36 Tank 241-T-109 Analytical Results: Thallium . . . . . . . . . . . . B-22

B2-37 Tank 241-T-109 Analytical Results: Titanium . . . . . . . . . . B-23

B2-38 Tank 241-T-109 Analytical Results: Uranium . . . . . . . . . . . . . B-23

B2-39 Tank 241-T-109 Analytical Results: Vanadium . . . . . . . . . . . B-23

B2-40 Tank 241-T-109 Analytical Results: Zinc . . . . . . . . . . . . . . . B B-24

B2-41 Tank 241-T-109 Analytical Results: Zirconium . . . . . . . . . . . . . . B-24

B2-42 Tank 241-T-109 Analytical Results: Bromide . . . . . . . . . . . . . B-24

B2-43 Tank 241-T-109 Analytical Results: Chloride . . . . . . . . . . . . B-25

B2-44 Tank 241-T-109 Analytical Results: Fluoride . . . . . . . . . . . . B-25

B2-45 Tank 241-T-109 Analytical Results: Nitrate . . . . . . . . . . . . B-25

B2-46 Tank 241-T-109 Analytical Results: Nitrite . . . . . . . . . . . . B-26

B2-47 Tank 241-T-109 Analytical Results: Oxalate . . . . . . . . . . . . B-26

B2-48 Tank 241-T-109 Analytical Results: Phosphate . . . . . . . . . . . . B-26 


\section{LIST OF TABLES (Continued)}

B2-49 Tank 241-T-109 Analytical Results: Sulfate . . . . . . . . . . . . . . B-27

B2-50 Results of Vapor Phase Measurements of Tank 241-T-109 . . . . . . . B-27

B2-51 Supernatant Sample $\ldots \ldots \ldots \ldots \ldots \ldots \ldots \ldots \ldots \ldots \ldots$ B-28

B3-1 Cation Mass and Charge Data $\ldots \ldots \ldots \ldots \ldots \ldots \ldots \ldots$ B-32

B3-2 Anion Mass and Charge Data $\ldots \ldots \ldots \ldots \ldots \ldots \ldots \ldots$ B-32

B3-3 Mass Balance Totals $\ldots \ldots \ldots \ldots \ldots \ldots \ldots \ldots \ldots \ldots$ B $\ldots \ldots \ldots$

B3-4 95\% Two-Sided Confidence Interval Limits on the Mean Concentration . . . . B-33

B3-5 Analytical-Based Inventory of Tank $241-\mathrm{T}-109 \ldots \ldots \ldots \ldots$. . . . . . . . .

C1-1 95 Percent Confidence Interval Upper Limits for Total Alpha for Tank

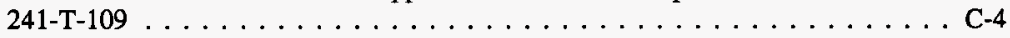

C2-1 Part 1 of Gateway Analysis $\ldots \ldots \ldots \ldots \ldots \ldots \ldots \ldots \ldots$

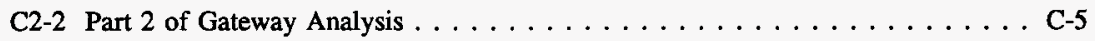

D2-1 Sampling- and HTCE-based Inventory Estimates for Nonradioactive Components in Tank 241-T-109 Waste . . . . . . . . . . D-4

D2-2 Sampling and Predicted Inventory Estimates for Radioactive Components in

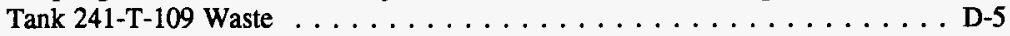

D2-3 Comparison of Selected Component Inventory Estimates for Tank 241-T-109 Waste . . . . . . . . . . . . . . . . . . . . D-6

D3-1 Comparison of Auger Sampling and HTCE Waste Compositions for Tank 241-T-109 on a Dry Weight Percent Basis . . . . . . . . . D-8

D3-2 Comparison of Auger Sampling and Modified HTCE Component Inventories for Tank 241-T-109 Waste on a Dry Weight Percent Basis . . . . . . . D-10

D4-1 Best-Basis Inventory Estimates for Tank 241-T-109

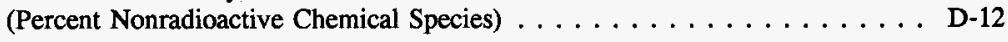

D4-2 Best-Basis Inventory Estimates for Tank $241-T-109 \ldots \ldots \ldots \ldots \ldots$. . . . . . . . 


\section{LIST OF TERMS}

1C

$\mu \mathrm{Ci} / \mathrm{g}$

$\mu \mathrm{Ci} / \mathrm{gal}$

$\mu \mathrm{g}$

$\mu \mathrm{g} / \mathrm{g}$

ASTM

BL

BNW

Btu/hr

Ci

$\mathrm{Ci} / \mathrm{L}$

CI

$\mathrm{cm}$

DOE

DQO

DSC

EB

Ecology

FIC

$\mathrm{ft}$

$\mathrm{g}$

$\mathrm{g} / \mathrm{L}$

$\mathrm{g} / \mathrm{mL}$

HDW

HTCE

IC

ICP

in.

IX

$\mathrm{J} / \mathrm{g}$

$\mathrm{kg}$

$\mathrm{kg} / \mathrm{L}$

kgal

$\mathrm{kL}$

$\mathrm{kW}$

L

LANL

LEL

LL

$\mathrm{m}$

M first cycle decontamination waste

microcuries per gram

microcuries per gallon

microgram

micrograms per gram

American Society for Testing and Materials

B Plant low-level waste

Battelle Northwest waste

British thermal units per hour

curies

curies per liter

confidence interval

centimeter

U. S. Department of Energy

data quality objectives

differential scanning calorimetry

evaporator bottoms

Washington State Department of Ecology

Food Instrument Corporation

feet

gram

grams per liter

grams per milliliter

Hanford defined waste

historical tank content estimate

ion chromatography

inductively coupled plasma spectroscopy

inch

ion exchange waste

joules per gram

kilogram

kilograms per liter

kilogallon

kiloliter

kilowatt

liter

Los Alamos National Laboratory

lower explosive limit

lower limit

meter

moles per liter 


\section{LIST OF TERMS (Continued)}

$\begin{array}{ll}\text { mm } & \text { millimeter } \\ \text { mrad/hr } & \text { millirads per hour } \\ \text { MT } & \text { metric ton } \\ \text { ppm } & \text { parts per million } \\ \text { SAP } & \text { sampling and analysis plan } \\ \text { SST } & \text { single-shell tank } \\ \text { T1SltCk } & \text { 242-T Evaporator saltcake waste, 1951-55 } \\ \text { TBP } & \text { tributyl phosphate } \\ \text { TCP } & \text { tank characterization plan } \\ \text { TCR } & \text { tank characterization report } \\ \text { TGA } & \text { thermogravimetric analysis } \\ \text { TIC } & \text { total inorganic carbon } \\ \text { TLM } & \text { tank layer model } \\ \text { TOC } & \text { total organic carbon } \\ \text { TWRS } & \text { Tank Waste Remediation System } \\ \text { UL } & \text { upper limit } \\ \text { UR } & \text { uranium recovery waste } \\ \text { W } & \text { watts } \\ \text { WSTRS } & \text { waste status and transaction record summary } \\ \text { wt\% } & \text { weight percent }\end{array}$


WHC-SD-WM-ER-559 Rev. 0

This page intentionally left blank. 


\subsection{INTRODUCTION}

One of the major functions of the Tank Waste Remediation System (TWRS) is to characterize wastes in support of waste management and disposal activities at the Hanford Site. Analytical data from sampling and analysis, along with other available information about a tank, are compiled and maintained in a tank characterization report (TCR). This report and its appendices serve as the TCR for single-shell tank 241-T-109. The objectives of this report are: 1) to use characterization data in response to technical issues associated with 241-T-109 waste; and 2) to provide a standard characterization of this waste in terms of a best-basis inventory estimate. The response to technical issues is summarized in Section 2.0, and the best-basis inventory estimate is presented in Section 3.0. Recommendations regarding safety status and additional sampling needs are provided in Section 4.0. Supporting data and information are contained in the appendices. This report also supports the requirements of the Hanford Federal Facility Agreement and Consent Order (Ecology et al. 1996) milestone M-44-09.

\subsection{SCOPE}

Characterization information presented in this report originated from sample analyses and known existing (historical) sources. While only the results of recent sample events will be used to fulfill the requirements of the data quality objectives (DQOs), other information can be used to support (or question) conclusions derived from these results. Historical information for tank 241-T-109, provided in Appendix A, included surveillance information, records pertaining to waste transfers and tank operations, and expected tank contents derived from a process knowledge model.

The recent sampling events listed in Table 1-1, as well as sample data obtained prior to 1989, are summarized in Appendix B along with the sampling results. The results of the 1995 sampling events, also reported in the laboratory data package (Conner 1995a), satisfied the data requirements specified in the tank characterization plan (TCP) for this tank (Conner 1995b). The statistical analysis and numerical manipulation of data used in issue resolution are reported in Appendix C. Appendix D contains the evaluation to establish the best basis for the inventory estimate and the statistical analysis performed for this evaluation. A bibliography that resulted from an in-depth literature search of all known information sources applicable to tank 241-T-109 and its respective waste types is contained in Appendix E. The reports listed in Appendix E may be found in the Tank Characterization Resource Center. 
Table 1-1. Summary of Recent Sampling.

\begin{tabular}{|c|c|c|c|c|c|}
\hline Gan & 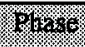 & Wogton & 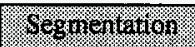 & 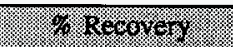 & $4 x_{1}$ \\
\hline $\begin{array}{l}\text { Vapor sample } \\
(8 / 15 / 95)\end{array}$ & Gas & $\begin{array}{l}\text { Tank headspace, } \\
\text { Riser } 6,6 \mathrm{~m} \\
(20 \mathrm{ft}) \text { below top } \\
\text { of riser }\end{array}$ & $n / a$ & $n / a$ & $n / a$ \\
\hline $\begin{array}{l}\text { Auger } \\
95-A U G-040 \\
(8 / 18 / 95)\end{array}$ & Solid & Riser 6 & $\begin{array}{l}\text { No } \\
\text { segmentation }\end{array}$ & $\begin{array}{l}\text { Unknown } \\
\text { (probably only top } \\
\text { of waste) }\end{array}$ & 67.5 \\
\hline $\begin{array}{l}\text { Auger } \\
95-A U G-041 \\
(8 / 21 / 95)\end{array}$ & Solid & Riser 2 & $\begin{array}{l}\text { Divided sample } \\
\text { in half (upper } \\
\text { and lower) }\end{array}$ & $\begin{array}{l}\text { Good recovery. } \\
\text { Bottom } 2.5 \text { to } \\
13 \mathrm{~cm} \text { ( } 1 \text { to } 5 \text { in.) } \\
\text { of the waste may } \\
\text { not be represented. }\end{array}$ & 232.5 \\
\hline $\begin{array}{l}\text { Vapor sample } \\
(5 / 9 / 96)\end{array}$ & Gas & $\begin{array}{l}\text { Tank headspace, } \\
\text { Riser } 6,6 \mathrm{~m} \\
\text { ( } 20 \mathrm{ft} \text { ) below top } \\
\text { of riser }\end{array}$ & $n / a$ & $\mathrm{n} / \mathrm{a}$ & $n / a$ \\
\hline
\end{tabular}

\subsection{TANK BACKGROUND}

Tank 241-T-109 is located in the 200 West Area T Tank Farm on the Hanford Site. It is the last tank in a three-tank cascade series. The tank went into service in 1945, receiving first cycle decontamination waste cascaded from tank 241-T-108. Supernate was transferred from the tank in 1951. During 1952 and 1953, uranium recovery waste was cascaded into tank 241-T-109. Supernate was transferred both into and out of the tank during 1953 and 1954, and in 1954, the tank received saltcake waste from the 242-T Evaporator. Additional supernate transfers into and out of the tank occurred from 1969 through 1976. The final transfer of waste occurred in 1983, when liquids were pumped from the tank in support of stabilization efforts.

A description of tank 241-T-109 is summarized in Table 1-2. The tank has an operating capacity of $2,010 \mathrm{~kL}(530 \mathrm{kgal})$, and presently contains an estimated $220 \mathrm{~kL}(58 \mathrm{kgal})$ of non-complexed waste (Hanlon 1996). The tank is not on the Watch List (Public Law 101-510). 
Table 1-2. Description of Tank 241-T-109.

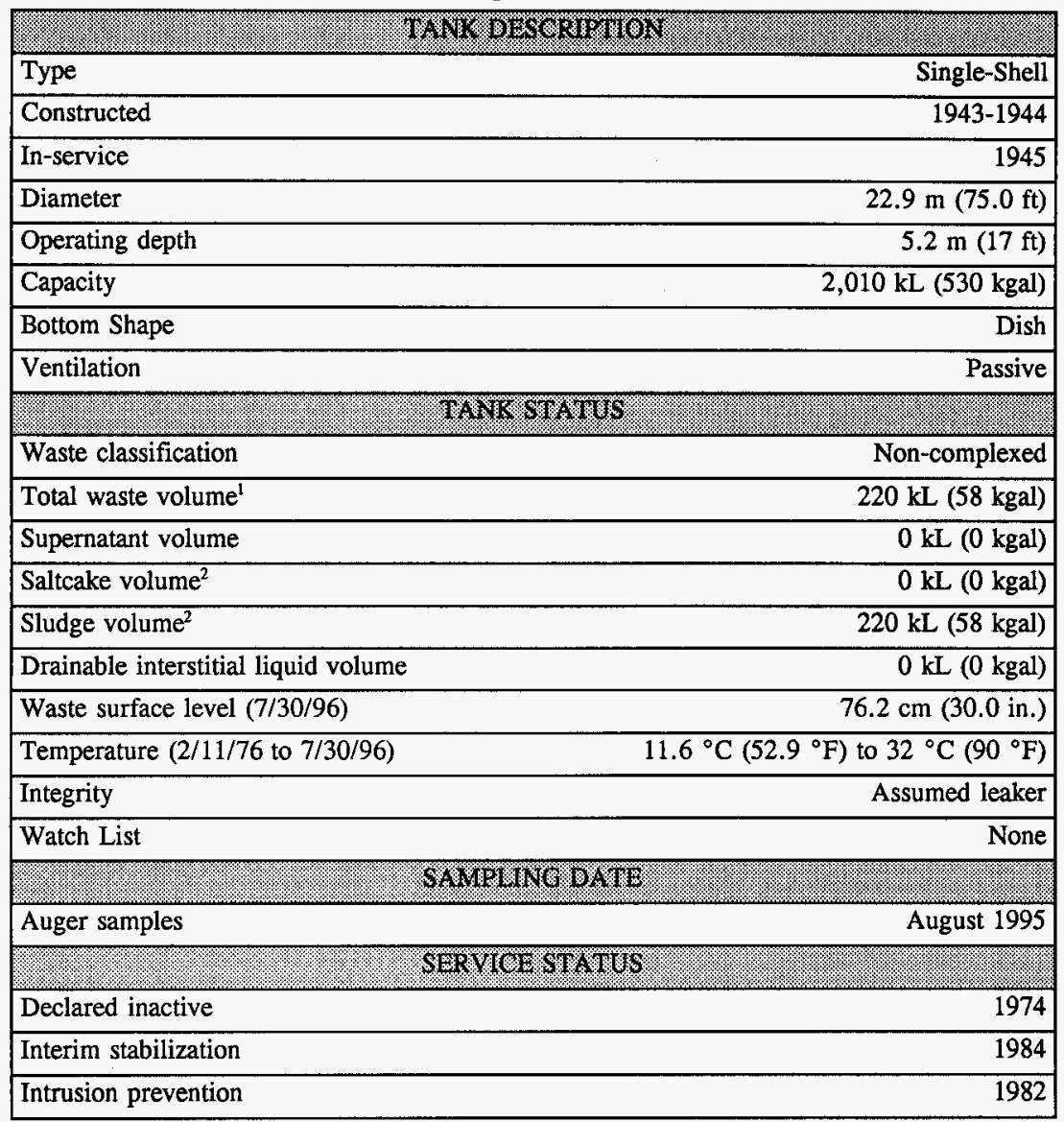

Note:

'Waste volume is estimated from surface level measurements.

${ }^{2}$ Although Hanlon (1996) reports that the tank contains all sludge waste, it is evident from the transfer history (Agnew et al. 1996b) and the auger samples (Conner 1995a) that the majority of the waste is probably saltcake. 
WHC-SD-WM-ER-559 Rev. 0

This page intentionally left blank. 


\subsection{RESPONSE TO TECHNICAL ISSUES}

Two technical issues have been identified for tank 241-T-109 (Brown et al. 1995). They are:

- Does the waste pose or contribute to any recognized potential safety problems?

- Is the waste inventory generated by a model based on process knowledge and historical information (Agnew et al. 1996b) representative of the current tank waste inventory?

The TCP (Conner 1995b) provides the types of sampling and analysis used to address the above issues. Data from the recent analysis of two auger samples and tank vapor space flammability measurements, as well as available historical information, provided the means to respond to these two issues. This response is detailed in the following sections. See Appendix B for sample and analysis data for tank 241-T-109.

\subsection{SAFETY SCREENING}

The data needed to screen the waste in tank 241-T-109 for potential safety problems is documented in Tank Safety Screening Data Quality Objective, Rev. 2 (Dukelow et al. 1995). These potential safety problems are exothermic conditions in the waste; flammable gases in the waste and/or tank headspace; and criticality conditions in the waste. Each of these conditions is addressed separately below. Because tank 241-T-109 is not a Watch List tank, the safety screening DQO was the only safety-related DQO associated with the sampling effort.

\subsubsection{Exothermic Conditions (Energetics)}

The first requirement outlined in the safety screening DQO (Dukelow et al. 1995) is to ensure that there are not enough exothermic constituents (organic or ferrocyanide) in tank 241-T-109 to cause a safety hazard. Because of this requirement, energetics in the tank 241-T-109 waste were evaluated. The safety screening DQO required that the waste sample profile be tested for energetics every $24 \mathrm{~cm}(9.5 \mathrm{in}$.) to determine if the energetics exceed the safety threshold limit. The threshold limit for energetics is $480 \mathrm{~J} / \mathrm{g}$ on a dry weight basis. Results obtained using differential scanning calorimetry indicated that no exotherms were apparent for any of the three samples (95-AUG-40, 95-AUG-41 upper, and 95-AUG-41 lower) (Conner 1995a). Note that auger sample 95-AUG-40 was not subdivided into an upper and lower sample because of the low recovery. Thus, the requirement of testing energetics for every $24 \mathrm{~cm}(9.5 \mathrm{in}$.) of the sample profile was met only for one of the two samples. 
Historically, there is no evidence that any exothermic agent should exist in this waste. Waste transfer records indicate that the major waste type expected to be in the tank is T1 saltcake, with a small possibility that some first-concentration-cycle waste from the bismuth phosphate process may be in the bottom of the tank (Agnew et al. 1996a). Neither of these waste types is expected to have organic or ferrocyanide constituents. Analysis of a sample taken in 1974 (Sant 1974) also showed no evidence of exotherms (see Appendix B).

\subsubsection{Flammable Gas}

Vapor phase measurements, taken in the tank headspace prior to the auger samples in August 1995 and again in May 1996, indicated that no flammable gas was detected ( 0 percent of the lower flammability limit). Data from these vapor phase measurements are presented in Appendix B.

\subsubsection{Criticality}

The safety threshold limit is $1 \mathrm{~g}{ }^{239} \mathrm{Pu}$ per liter of waste. Assuming that all alpha is from ${ }^{239} \mathrm{Pu}$ and assuming a density of $1.55 \mathrm{~g} / \mathrm{mL}, 1 \mathrm{~g} / \mathrm{L}$ of ${ }^{239} \mathrm{Pu}$ is equivalent to $40 \mu \mathrm{Ci} / \mathrm{g}$ of alpha activity. The auger samples were analyzed in accordance with an earlier revision of the safety screening DQO (Babad et al. 1995) which did not require density measurements. Because density was not measured, the density estimated by Agnew et al. (1996b) was used. Waste samples were tested for total alpha activity for each auger sample. Concentrations in all samples were well below this limit. Additionally, as required by the DQO, the upper limit of the one-sided 95 percent confidence interval for these results was less than $1 \mathrm{~g} / \mathrm{L}$. The method used to calculate confidence limits is contained in Appendix $C$.

\subsection{HISTORICAL EVALUATION}

The purpose of the historical evaluation is to determine whether the model based on process knowledge and historical information (Brevick et al. 1995, Agnew et al. 1996b) predicts tank inventories that are in agreement with current tank inventories. If the historical model can be shown to accurately predict the waste characteristics as observed through sample characterization, then there is a possibility that the amount of total sampling and analysis needed may be reduced. Data requirements for this evaluation are documented in Historical Model Evaluation Data Requirements, Rev. 0-A (Simpson and McCain 1995).

A "gateway" analysis is a quick check to ensure that the data obtained from sampling support the remainder of the historical evaluation analysis. Failure of the gateway analysis indicates that the model waste composition estimate is not comparable to the sample data and that the tank is not a good tank on which to perform the historical DQO. If the gateway analysis fails, the remainder of the sampling and analysis for the historical DQO will not be applied to the tank. If the gateway analysis passes, then further analyses will be performed on the 
waste samples as specified in the historical model evaluation DQO. Results of the historical model evaluation DQO will be used to quantify the errors associated with the historical tank content estimates (HTCE).

The gateway analysis was applied to each of the auger samples taken from tank 241-T-109 in August 1995. The gateway analytes for tank 241-T-109 are sodium, water, nitrate, phosphate, and fluoride. These analytes were chosen because the tank waste is predicted to be composed entirely of saltcake waste generated from the 242-T evaporator from 1951 through 1955 (T1SltCk). The gateway analysis required two tests be performed for each sample. The first test was to determine if the gateway analytes contributed to more than 85 percent (by mass) of the total waste. The second test was to determine if the concentration of each of the gateway analytes was over 10 percent of the predicted concentration (as specified in the DQO). The gateway analysis for tank 241-T-109 is shown in Appendix C.

The first test in the gateway analysis passed; water, sodium, and phosphate alone contributed to over 90 percent of the waste mass. The second test, however, failed for each segment. In sample 95-AUG-40, the fluoride was less than 10 percent of the predicted value. In the 95-AUG-41 upper and lower samples, the nitrate was less than 10 percent of the predicted value. Phosphate appeared to be the predominant anion in all samples. If the historical model evaluation DQO had used the average of the two auger samples, both fluoride and nitrate would have been greater than 10 percent of the predicted value and the samples would have passed the second test.

Because the gateway analysis for tank 241-T-109 failed, the remainder of the sample analyses specified in the historical model evaluation DQO will not be performed for the tank. The likely reason for the gateway analysis failure is that the model predicts the presence of just one waste type (T1SltCk) when other wastes were also received by the tank. Further evaluation will be performed later to determine the specific reason why the gateway analysis failed. See Section D1.4 in Appendix D for conclusions about the tank waste contents.

\subsection{OTHER TECHNICAL ISSUES}

A factor in assessing tank safety is the heat generation and temperature of the waste. Heat is generated in the tanks from radioactive decay. An estimate of the tank heat load based on the 1995 sample event was not possible because radionuclide analyses were not required. However, the heat load estimate based on the tank process history was $44.7 \mathrm{~W}(153 \mathrm{Btu} / \mathrm{hr})$ (Agnew et al. 1996b). The heat load estimate based on the tank headspace temperature was $518 \mathrm{~W}(1,770 \mathrm{Btu} / \mathrm{hr})$ (Kummerer 1994). Both of these estimates are quite low, and are well below the limit of $11,700 \mathrm{~W}(40,000 \mathrm{Btu} / \mathrm{hr})$ that separates high- and low-heat-load tanks (Bergmann 1991.) 


\subsection{SUMMARY}

The results from all analyses performed to address potential safety issues showed that no primary analyte exceeded safety decision threshold limits. Some uncertainty exists as to whether or not the auger samples included waste from the bottom of the tank. There is, however, no indication that any waste type other than T1SltCk or first concentration cycle waste exists in the tank. Both these waste types have no exothermic constituents and do not represent a safety hazard. The gateway analysis for the historical evaluation DQO failed; thus, no further analyses from the historical DQO will be applied to this tank. The analyses results are summarized in Table 2-1.

Table 2-1. Summary of Safety Screening and Historical Evaluation Results.

\begin{tabular}{|l|l|l|}
\hline \multirow{2}{*}{$\begin{array}{l}\text { Safety } \\
\text { screening }\end{array}$} & Energetics & No exotherms observed in any sample. \\
\cline { 2 - 3 } & Flammable gas & $\begin{array}{l}\text { Vapor measurement reported 0 percent of lower } \\
\text { flammability limit. (Combustible gas meter). }\end{array}$ \\
\cline { 2 - 3 } & Criticality & $\begin{array}{l}\text { All analyses well below } 41 \mu \mathrm{Ci} / \mathrm{g} \text { total alpha (within } \\
95 \text { percent confidence limit on each sample). }\end{array}$ \\
\hline $\begin{array}{l}\text { Historical } \\
\text { (gateway } \\
\text { analysis) }\end{array}$ & $\begin{array}{l}\text { Total mass of } \\
\text { indicators }\end{array}$ & $\begin{array}{l}\text { Passed - Indicator analytes contribute over 95 percent } \\
\text { of total waste mass. }\end{array}$ \\
\cline { 2 - 3 } & $\begin{array}{l}\text { Comparison of } \\
\text { each indicator }\end{array}$ & Failed. \\
\hline
\end{tabular}




\subsection{BEST-BASIS INVENTORY ESTIMATE}

Information about the chemical and/or physical properties of tank wastes is used to perform safety analyses, engineering evaluations, and risk assessments associated with waste management activities, as well as to address regulatory issues. Waste management activities include overseeing tank farm operations and identifying, monitoring, and resolving safety issues associated with these operations and with the tank wastes. Disposal activities involve designing equipment, processes, and facilities for retrieving wastes and processing the wastes into a form that is suitable for long-term storage. Chemical inventory information generally is derived using two approaches: 1) component inventories are estimated using the results of sample analyses; and 2) component inventories are predicted using a model based on process knowledge and historical information. The most recent model was developed by Los Alamos National Laboratory (LANL) (Agnew et al. 1996b). Not surprisingly, information derived from these two different approaches is often inconsistent.

An effort is underway to provide waste inventory estimates that will serve as standard characterization information for the various waste management activities (Kupfer et al. 1995). As part of this effort, an evaluation of available chemical information for tank 241-T-109 was performed that included:

- Data from recent analyses of two auger samples collected in August 1995 (Conner 1995a)

- Data from the analysis of supernatant sample T-2289 collected in 1974

- The solids composite inventory estimate for this tank generated from the LANL model (Agnew et al. 1996b), also referred to as the historical tank content estimate (HTCE).

Results from this evaluation, detailed in Appendix D, support using the sampling data as the basis for the best estimate inventory for tank $241-\mathrm{T}-109$ for the following reasons:

1. The inventory estimate generated by the LANL model is based on a single defined salt waste stream (T1SltCk) and does not take into account any solids contributions and/or waste dilution effects from the $1,431 \mathrm{~kL}$ (378 kgal) of waste transferred from $\mathrm{T}-108$ to $\mathrm{T}-109$ in 1973 . This $1,431 \mathrm{~kL}$ is not considered to be T1SltCk and would most likely alter the composition of the $515 \mathrm{~kL}$ (136 kgal) of salt waste in the tank at that time.

2. Phosphate concentration values, which appear consistent for all analyzed segments, suggest that phosphates formed the bulk of the precipitated solids. The predicted concentration value for this major component is less than half of 
the lower limit of the two-sided 95 percent confidence interval on the mean. The LANL assumption that only 40 percent of the phosphate in the T1 waste stream precipitates appears to be conservative.

Best-basis inventory estimates for tank 241-T-109 are presented in Tables 3-1 and 3-2. While samples were analyzed for numerous analytes, only those detected in the waste are included in these tables. Table 3-1 provides an inventory estimate in terms of percent (expected) chemical species. Note that this waste is predominantly sodium phosphate and should not be mixed with waste types that could result in phosphate gels. Table 3-2 lists compound inventories along with the analytical concentrations that were used to calculate these inventories. A tank volume of $220 \mathrm{~kL}$ (58 kgal) (Hanlon 1996) and a density of $1.55 \mathrm{~g} / \mathrm{mL}$ (Agnew et al. 1996b) were used to calculate these inventories.

Table 3-1. Best-Basis Inventory Estimate for Tank 241-T-109 (Percent Nonradioactive Chemical Species).

\begin{tabular}{|c|c|c|}
\hline \multicolumn{2}{|c|}{ 6omorino } & 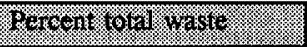 \\
\hline \multicolumn{2}{|l|}{ Water } & 48 \\
\hline \multicolumn{2}{|l|}{ Sodium phosphate ${ }^{1}$} & $40-44$ \\
\hline \multicolumn{2}{|l|}{ Sodium fluoride } & 2.9 \\
\hline \multicolumn{2}{|l|}{ Sodium nitrate } & 2.9 \\
\hline \multicolumn{2}{|l|}{ Sodium nitrite $^{2}$} & $0.074-2.3$ \\
\hline \multicolumn{2}{|l|}{ Sodium sulfate ${ }^{2}$} & $0.076-0.75$ \\
\hline \multicolumn{2}{|l|}{ Sodium carbonate ${ }^{3}$} & $0.48-1.8$ \\
\hline \multicolumn{2}{|l|}{ Minor compounds: } & 1.6 \\
\hline Iron hydroxide & 0.87 & \\
\hline Aluminum hydroxide & 0.36 & \\
\hline Silicon dioxide & 0.19 & \\
\hline Manganese hydroxide & 0.17 & \\
\hline Calcium carbonate & 0.081 & \\
\hline Sodium chloride & 0.047 & \\
\hline Zinc hydroxide & 0.029 & \\
\hline Bismuth oxide & 0.019 & \\
\hline
\end{tabular}

Notes:

'Range accounts for range in sodium sulfate, sodium nitrite, and sodium carbonate inventories; refer to (2) and (3) below.

${ }^{2}$ Low value based on auger sample analysis; high value based on 1974 supernatant analysis. The 1974 data have not been validated and should be used with caution.

${ }^{3} \mathrm{Low}$ value based on 0.542 percent $\mathrm{CO}_{3}$ in supernatant sample, and high value based on $0.542 \underline{\mathrm{M}} \mathrm{CO}_{3}$. 
Table 3-2. Best-Basis Inventory Estimates for 241-T-109. (2 Sheets)

\begin{tabular}{|c|c|c|c|c|c|}
\hline 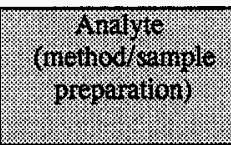 & 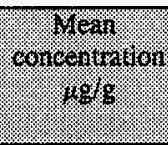 & 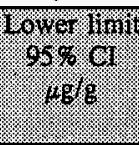 & 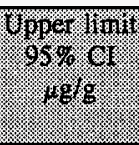 & 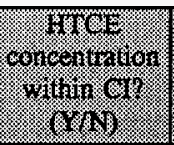 & 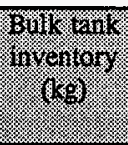 \\
\hline $\begin{array}{l}\mathrm{Al} \\
\text { (ICP/Fusion) }\end{array}$ & 1,250 & 0 & 3,300 & Y & 430 \\
\hline $\begin{array}{l}\mathrm{Bi}^{1} \\
\text { (ICP/Acid) }\end{array}$ & 170 & $\mathrm{n} / \mathbf{a}$ & $n / a$ & $\mathrm{n} / \mathrm{a}$ & 58 \\
\hline $\begin{array}{l}\text { B } \\
\text { (ICP/Acid) }\end{array}$ & 217 & $\mathrm{n} / \mathrm{a}$ & $\mathrm{n} / \mathrm{a}$ & $\mathrm{n} / \mathbf{a}$ & 74 \\
\hline $\begin{array}{l}\mathrm{Ca}^{1} \\
\text { (ICP/Acid) }\end{array}$ & 324 & $\mathrm{n} / \mathrm{a}$ & $n / a$ & $\mathrm{n} / \mathrm{a}$ & 110 \\
\hline $\begin{array}{l}\mathrm{Cl}^{1} \\
\text { (IC/Water) }\end{array}$ & 341 & $\mathrm{n} / \mathrm{a}$ & $\mathrm{n} / \mathrm{a}$ & $\mathrm{n} / \mathrm{a}$ & 120 \\
\hline $\begin{array}{l}\mathrm{Cr}^{1} \\
\text { (ICP/Acid) }\end{array}$ & 40 & $\mathrm{n} / \mathrm{a}$ & $\mathrm{n} / \mathrm{a}$ & $\mathrm{n} / \mathrm{a}$ & 14 \\
\hline $\begin{array}{l}\mathbf{F} \\
\text { (IC/Water) }\end{array}$ & 13,000 & 0 & 168,000 & $\bar{Y}$ & 4,500 \\
\hline \begin{tabular}{|l|l}
$\mathrm{Fe}$ \\
(ICP/Fusion)
\end{tabular} & 5,490 & 0 & 26,800 & $\bar{Y}$ & 1,900 \\
\hline $\begin{array}{l}\mathrm{Pb} \\
\text { (ICP/Acid) }\end{array}$ & 303 & $\mathrm{n} / \mathrm{a}$ & $\mathrm{n} / \mathrm{a}$ & $\mathrm{n} / \mathrm{a}$ & 100 \\
\hline $\begin{array}{l}\mathrm{Mg} \\
\text { (ICP/Acid) }\end{array}$ & 111 & $\mathrm{n} / \mathrm{a}$ & $n / a$ & $n / a$ & 38 \\
\hline $\begin{array}{l}\mathrm{Mn} \\
\text { (ICP/Fusion) }\end{array}$ & 1,030 & 0 & 7,060 & $\bar{Y}$ & 350 \\
\hline $\begin{array}{l}\mathrm{Na} \\
\text { (ICP/Fusion) }\end{array}$ & 181,000 & $\overline{0}$ & 370,000 & $\mathbf{Y}$ & $62,000^{2}$ \\
\hline $\begin{array}{l}\mathrm{NO}_{2}{ }^{7} \\
\mathrm{IC} / \text { Water) }\end{array}$ & $\begin{array}{c}492- \\
15,000\end{array}$ & $\bar{n} / \mathrm{a}$ & $\bar{n} / \mathbf{a}$ & $\mathrm{n} / \mathrm{a}$ & $\begin{array}{l}170- \\
5,100\end{array}$ \\
\hline $\begin{array}{l}\mathrm{NO}_{3} \\
\text { (IC/Water) }\end{array}$ & 20,800 & $\overline{0}$ & 241,000 & $\overline{\mathbf{Y}}$ & 7,100 \\
\hline $\begin{array}{l}\mathrm{P} \text { as } \mathrm{PO}_{4} \\
\text { (ICP/Fusion, } \\
\text { IC/Water) }\end{array}$ & $\begin{array}{l}269,000- \\
246,000^{3}\end{array}$ & 198,000 & 331,000 & $\overline{\mathbf{N}}$ & $\begin{array}{l}92,000- \\
83,000^{4}\end{array}$ \\
\hline $\begin{array}{l}\mathrm{Si} \\
\text { (ICP/Fusion) }\end{array}$ & 889 & $\mathrm{n} / \mathrm{a}$ & $\mathrm{n} / \mathrm{a}$ & $\mathrm{n} / \mathrm{a}$ & 300 \\
\hline \begin{tabular}{|l}
$\mathrm{Ag}$ \\
(ICP/Acid)
\end{tabular} & 18.6 & $\mathrm{n} / \mathrm{a}$ & $\mathrm{n} / \mathrm{a}$ & $\mathrm{n} / \mathrm{a}$ & 6 \\
\hline
\end{tabular}


Table 3-2. Best-Basis Inventory Estimates for 241-T-109. (2 Sheets)

\begin{tabular}{|c|c|c|c|c|c|}
\hline (1) & 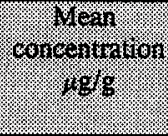 & . & 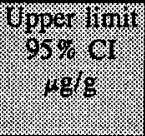 & 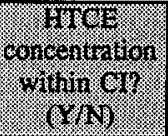 & 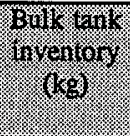 \\
\hline $\begin{array}{l}\mathrm{S} \text { as } \mathrm{SO}_{4}^{1,7} \\
\text { (ICP/Acid) }\end{array}$ & $\begin{array}{l}516- \\
5,050\end{array}$ & $\mathrm{n} / \mathrm{a}$ & $\mathrm{n} / \mathrm{a}$ & $\mathrm{n} / \mathrm{a}$ & $\begin{array}{l}180- \\
1,700\end{array}$ \\
\hline TIC as $\mathrm{CO}_{3}{ }^{1,5}$ & $\begin{array}{l}2,710- \\
10,400\end{array}$ & $\mathrm{n} / \mathrm{a}$ & $\mathrm{n} / \mathrm{a}$ & $\mathrm{n} / \mathrm{a}$ & $\begin{array}{l}920- \\
3,600\end{array}$ \\
\hline $\begin{array}{l}\mathrm{Zn} \\
\text { (ICP/Fusion) }\end{array}$ & 276 & 47.3 & 505 & $\begin{array}{c}\text { Not } \\
\text { Reported }\end{array}$ & 95 \\
\hline $\begin{array}{l}\mathrm{Zr} \\
\text { (ICP/Acid) }\end{array}$ & 12.2 & $\mathrm{n} / \mathrm{a}$ & $\bar{n} / \mathrm{a}$ & $\mathrm{n} / \mathrm{a}$ & 4 \\
\hline Total $\alpha(\mu \mathrm{Ci} / \mathrm{g})$ & 0.0137 & 0 & 0.1 & $\bar{Y}$ & $4.7 \mathrm{Ci}$ \\
\hline $\mathrm{H}_{2} \mathrm{O}(\mathrm{wt} \%)$ & 47.7 & 38.1 & 57.3 & $\overline{\mathbf{Y}}$ & $48 w t \%$ \\
\hline Density $(\mathrm{g} / \mathrm{mL})^{6}$ & 1.55 & $\mathrm{n} / \mathrm{a}$ & $\mathrm{n} / \mathrm{a}$ & $\mathrm{n} / \mathrm{a}$ & 1.55 \\
\hline
\end{tabular}

Key:

CI Confidence level

IC Ion chromatography

ICP Inductively coupled plasma spectroscopy

TIC Total organic carbon

Water Approximately $1 \mathrm{~g}$ sample is contacted with $100 \mathrm{~mL}$ water; solution analyzed by IC.

Acid Sample is digested with acid; solution analyzed by ICP.

Fusion Sample is fused with $\mathrm{KOH}$ at high temperatures to form a "melt, " which is subsequently dissolved with water; solution analyzed by ICP.

n/a not applicable

Notes:

${ }^{1}$ Analyte detected in only one sample; insufficient data to calculate confidence intervals.

${ }^{2} \mathrm{Na}$ inventory is based on $178,000 \mu \mathrm{g} \mathrm{Na} / \mathrm{g}$ waste for ion balance purposes, assuming $\mathrm{Na}_{2.5} \mathrm{H}_{0.5} \mathrm{PO}_{4}$.

${ }^{3}$ Range reflects mean analyte concentrations from ICP and IC analyses.

${ }^{4} \mathrm{PO}_{4}$ inventory of $92,000 \mathrm{~kg}$ is based on $269,000 \mu \mathrm{g} \mathrm{PO} / \mathrm{g}$ waste; lower inventory value accounts for uncertainties in $\mathrm{NO}_{2}, \mathrm{SO}_{4}$, and TIC as $\mathrm{CO}_{3}$ inventories.

${ }^{5}$ Auger samples not analyzed for $\mathrm{CO}_{3}$; concentration has been estimated from supernatant data.

Concentration in the supernatant sample was reported as " 0.542 " with no units. The lower concentration/inventory value is based on 0.542 percent $\mathrm{CO}_{3}$ and the higher concentration/inventory value is based on $0.542 \underline{\mathrm{M} \mathrm{CO}}$.

${ }^{6}$ Density analyses not performed with auger samples. Density of $1.55 \mathrm{~kg} / \mathrm{L}$ was generated by LANL and is consistent with a densities of $1.6 \mathrm{~g} / \mathrm{mL}$ for $\mathrm{Na}_{3} \mathrm{PO}_{4} \cdot 12 \mathrm{H}_{2} \mathrm{O}$ and $1.5 \mathrm{~g} / \mathrm{mL}$ for $\mathrm{Na}_{2} \mathrm{HPO}_{4} \cdot 12 \mathrm{H}_{2} \mathrm{O}$.

${ }^{7}$ Low value based on auger sample analysis; high value based on 1974 supernatant analysis. The 1974 data have not been validated and should be used with caution. 


\subsection{RECOMMENDATIONS}

All analytical results for the safety screening DQO were well within the safety notification limits. However, the full depth of the waste was not sampled. Therefore, the tank cannot yet be classified as "safe." The gateway analysis for the historical DQO failed, indicating that no further sampling and analysis of tank 241-T-109 will be performed to support this DQO. Further evaluation of the available data will be performed at a later time to determine why the gateway analysis failed. The sampling and analysis activities performed for tank 241-T-109 have met all requirements for all of the applicable DQO documents. Furthermore, a characterization best-basis inventory was developed for the tank contents.

Table 4-1 summarizes the status of TWRS Program review and acceptance of the sampling and analysis results reported in this tank characterization report. All DQO issues required to be addressed by sampling and analysis are listed in column one of Table 4-1. The second column indicates whether the requirements of the DQO were met by the sampling and analysis activities performed and is answered with a "yes" or a "no." The third column indicates concurrence and acceptance by the program in TWRS that is responsible for the DQO that the sampling and analysis activities performed adequately meet the needs of the DQO. A "yes" or "no" in column three indicates acceptance or disapproval of the sampling and analysis information presented in the TCR. If the results/information have not yet been reviewed, "N/R" is shown in the column. If the results/information have been reviewed, but acceptance or disapproval has not been decided, "N/D" is shown in the column. Because the waste at the bottom of the tank was not sampled (see Section B3.1) the safety screening DQO has been only partially completed. The upper part of the waste was sampled and analyzed in accordance with the safety screening DQO and accepted by the responsible TWRS program.

Table 4-1. Acceptance of Tank 241-T-109 Sampling and Analysis.

\begin{tabular}{|c|c|c|}
\hline 18340 & Eorativation & $\begin{array}{l}\text { MRes progran } \\
\text { accoptanes: }\end{array}$ \\
\hline Safety Screening DQO & Partial & Partial \\
\hline Historical Evaluation DOO & Yes & Yes \\
\hline
\end{tabular}

Note:

$\mathrm{N} / \mathrm{R}=$ Not reviewed

Table 4-2 summarizes the status of TWRS Program review and acceptance of the evaluations and other characterization information contained in this report. The evaluations specifically outlined in this report are the best-basis inventory evaluation, the gateway analysis, and the evaluation to determine whether the tank is safe, conditionally safe, or unsafe. Column one lists the different evaluations performed in this report. Columns two and three are in the 
Table 4-2. Acceptance of Evaluation of Characterization Data and Information for Tank 241-T-109.

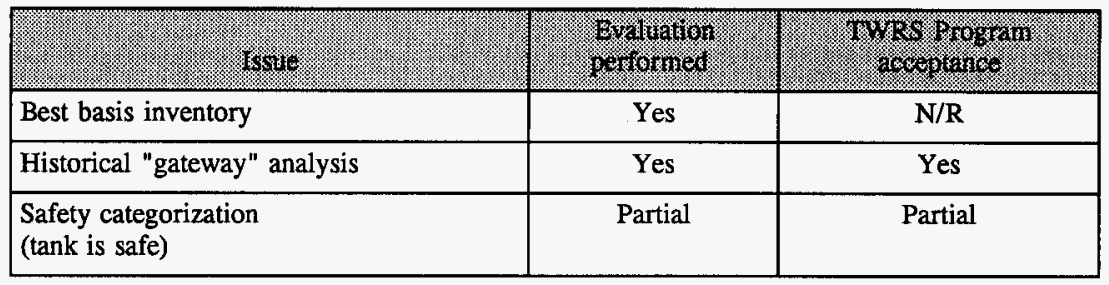

Note:

$$
\mathrm{N} / \mathrm{R}=\text { Not reviewed }
$$

same format as Table 4-1. The manner in which concurrence and acceptance are summarized is also the same as that in Table 4-1. The safety categorization of the tank is listed as "partial" in Table 4-2 because the full depth of the waste was not sampled. However, none of the analyses performed on the auger samples indicate any safety problems.

Resampling of tank 241-T-109 using push-mode core sampling has been recommended in order to provide the two full depth profiles required by the safety screening DQO (Kirch 1995, Conner 1995c). Further evaluation of the information available on tank 241-T-109 is recommended to determine if additional samples are needed to categorize the tank as "safe."

One final comment regarding the safety screening DQO needs to be made. The one-sided confidence intervals that were used to determine whether or not ${ }^{239} \mathrm{Pu}$ is below the DQO stated threshold limit were performed solely on each individual sample as required by the DQO. 


\subsection{REFERENCES}

Agnew, S. F., R. A. Corbin, T. B. Duran, K. A. Jurgensen, T. P. Ortiz, and B. L. Young, 1996a, Waste Status and Transaction Record Summary for the Northwest Quadrant of the Hanford 200 East Area, WHC-SD-WM-TI-669, Rev. 1, Westinghouse Hanford Company, Richland, Washington.

Agnew, S. F., J. Boyer, R. A. Corbin, T. B. Duran, J. R. Fitzpatrick, K. A. Jurgensen, T. P. Ortiz, and B. L. Young, 1996b, Hanford Tank Chemical and Radionuclide Inventories: HDW Model Rev. 3, LA-UR-96-858, Los Alamos National Laboratory, Los Alamos, New Mexico.

Babad, H., J. W. Hunt, and K. S. Redus, 1995, Tank Safety Screening Data Quality Objective, WHC-SD-WM-SP-004, Rev. 1, Westinghouse Hanford Company, Richland, Washington.

Bergmann, L. M., 1991, Single-Shell Tank Isolation Safety Analysis Report, WHC-SD-WM-SAR-006, Rev. 2, Westinghouse Hanford Company, Richland, Washington.

Brevick, C. H., L. A. Gaddis, and E. D. Johnson, 1995, Historical Tank Content Estimate for the Northwest Quadrant of the Hanford 200 East Areas, WHC-SD-WM-ER-351, Rev. 0, Westinghouse Hanford Company, Richland, Washington.

Brown, T. M., S. J. Eberlein, and T. J. Kunthara, 1995, Tank Waste Characterization Basis, WHC-SD-WM-TA-164, Rev. 1, Westinghouse Hanford Company, Richland, Washington.

Conner, J. M., 1995a, Final Report for Tank 241-T-109, Auger Samples 95-AUG-040 and 95-AUG-041, WHC-SD-WM-DP-144, Rev. 1A, Westinghouse Hanford Company, Richland, Washington.

Conner, J. M., 1995b, Tank 241-T-109 Tank Characterization Plan, WHC-SD-WM-TP-368, Rev. 0, Westinghouse Hanford Company, Richland, Washington.

Conner, J. M., 1995c, Need Identified to Resample Tank 241-T-109, (Internal Memo 75310-95-098 to T. J. Kelley, October 24), Westinghouse Hanford Company, Richland, Washington.

Dukelow, G. T., J. W. Hunt, H. Babad, and J. E. Meacham, 1995, Tank Safety Screening Data Quality Objective, WHC-SD-WM-SP-004, Rev. 2, Westinghouse Hanford Company, Richland, Washington. 
Ecology, EPA and DOE, 1996, Hanford Federal Facility Agreement and Consent Order, as amended, Washington State Department of Ecology, U.S. Environmental Protection Agency, and U.S. Department of Energy, Olympia, Washington.

Hanlon, B. M., 1996, Waste Tank Summary Report for Month Ending April 30, 1996, WHC-EP-0182-97, Westinghouse Hanford Company, Richland, Washington.

Kirch, N. W., 1995, Tank Data Review Committee, (Meeting Minutes to Distribution, October 18), Westinghouse Hanford Company, Richland, Washington.

Kummerer, M., 1994, Topical Report on Heat Removal Characteristics of Waste Storage Tanks, WHC-SD-WM-SARR-010, Rev. 0, Westinghouse Hanford Company, Richland, Washington.

Kupfer, M. J., M. D. LeClair, W. W. Schulz, and L. W. Shelton, 1995, Work Plan for Defining a Standard Inventory Estimate for Wastes Stored in Hanford Site Underground Tanks, WHC-SD-WM-WP-311, Rev. 0, Westinghouse Hanford Company, Richland, Washington.

Public Law 101-510, 1990, "Safety Measures for Waste Tanks at Hanford Nuclear Reservation," Section 3137 of National Defense Authorization Act for Fiscal Year 1991.

Sant, W. H., 1974, Analysis of Tank Farm Samples, Sample: T-2289, Tank 109-T, (internal memorandum to R. L. Walser, March 13), Atlantic Richfield Hanford Company, Richland, Washington.

Simpson, B. C. and D. J. McCain, 1995, Historical Model Evaluation Data Requirements, WHC-SD-WM-DQO-018, Rev. 0-A, Westinghouse Hanford Company, Richland, Washington. 
WHC-SD-WM-ER-559 Rev. 0

APPENDIX A

HISTORICAL TANK INFORMATION 
WHC-SD-WM-ER-559 Rev. 0

This page intentionally left blank. 


\section{APPENDIX A}

\section{HISTORICAL TANK INFORMATION}

Appendix A describes tank 241-T-109 based on historical information. For this report, historical information includes any information about the fill history, waste types, surveillance, or modeling data about the tank. This information is necessary for providing a balanced assessment of the sampling and analytical results.

This appendix contains the following information:

- Section A1: Current status of the tank, including the current waste levels as well as the stabilization and isolation status of the tank.

- Section A2: Information about the design of the tank.

- Section A3: Process knowledge of the tank; i.e., the waste transfer history and the estimated contents of the tank based on modeling data.

- Section A4: Surveillance data for tank 241-T-109, including surface-level readings, temperatures, and a description of the waste surface based on photographs.

- Section A5: References for Appendix A.

Historical sampling results (results from samples obtained prior to 1989) are included in Appendix B.

\section{A1.0 CURRENT TANK STATUS}

As of April 30, 1996, tank 241-T-109 contained an estimated $220 \mathrm{~kL}$ (58 kgal) of non-complexed waste (Hanlon 1996). The waste volumes were estimated using a manual tape surface-level gauge. The volumes of the waste phases found in the tank are shown in Table A1-1.

In 1974, tank 241-T-109 was declared an assumed leaker and removed from service. It was interim stabilized in 1984; intrusion prevention (interim isolation) was completed in December 1982. The tank is passively ventilated and is not on the Watch List (Public Law 101-510). 
Table A1-1. Tank Contents Status Summary (Hanlon 1996).

\begin{tabular}{|l|l|}
\hline & Waste ype \\
\hline Total waste & $220(58)$ \\
\hline Supernatant & $0(0)$ \\
\hline Sludge $^{1}$ & $220(58)$ \\
\hline Saltcake $^{1}$ & $0(0)$ \\
\hline Drainable interstitial liquid & $0(0)$ \\
\hline Drainable liquid remaining & $0(0)$ \\
\hline Pumpable liquid remaining & $0(0)$ \\
\hline
\end{tabular}

Note:

${ }^{1}$ Although the Waste Status Summary Report (Hanlon 1996) reports that the tank contents are all sludge waste, it is evident from the transfer history (Agnew et al. 1996a) and the appearance of the auger samples that the majority of the waste is probably saltcake.

\section{A2.0 TANK DESIGN AND BACKGROUND}

Tank 241-T-109 was constructed during 1943 and 1944. It is one of twelve 2,010-kL (530-kgal) tanks in T Farm. These tanks were designed for nonboiling waste with a maximum fluid temperature of $104^{\circ} \mathrm{C}\left(220^{\circ} \mathrm{F}\right)$. A typical T Farm tank contains 9 to 11 risers ranging in size from $10 \mathrm{~cm}(4 \mathrm{in}$.) to $1.1 \mathrm{~m} \mathrm{(42} \mathrm{in.)} \mathrm{in} \mathrm{diameter} \mathrm{that} \mathrm{provide}$ surface-level access to the underground tank. Generally, there is one riser through the center of the tank dome and four or five each on opposite sides of the dome.

Tank 241-T-109 entered service in 1945 and is third in a three-tank cascading series. These tanks are connected by a 7.6-cm (3-in.) cascade line. The bottom center elevation of tank

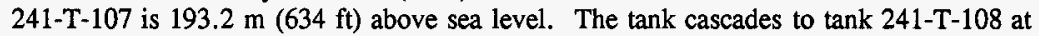
$193.0 \mathrm{~m}(633 \mathrm{ft})$, which then cascades to tank $241-\mathrm{T}-109$, which has a bottom center elevation at $192.3 \mathrm{~m}(631 \mathrm{ft})$. The cascade overflow height is approximately $4.78 \mathrm{~m}$ (188 in.) from the tank bottom and $60 \mathrm{~cm}(2 \mathrm{ft})$ below the top of the steel liner.

These single-shell tanks (SSTs) are constructed of 30-cm (1-ft)-thick reinforced concrete with a $6.4 \mathrm{~mm}(1 / 4 \mathrm{in}$.) mild carbon steel liner (ASTM A283 Grade C) on the bottom and sides and a $38-\mathrm{cm}(1.25-\mathrm{ft})$-thick domed concrete top. These tanks have a dished bottom with a $1.2-\mathrm{m}(4-\mathrm{ft})$ radius knuckle and a $5.18-\mathrm{m}(17-\mathrm{ft})$ operating depth. The tanks are set on a reinforced concrete foundation. 
A three-ply cotton fabric waterproofing was applied over the foundation and the steel tank. Four coats of primer paint were sprayed on all exposed interior tank surfaces. Tank ceiling domes were covered with three applications of magnesium zincfluorosilicate wash. Lead flashing was used to protect the joint where the steel liner meets the concrete dome. Asbestos gaskets were used to seal the access holes in the tank dome. The tanks were waterproofed on the sides and top with tar and gunite. Each tank was covered with

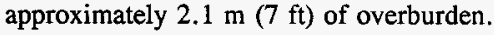

The surface level is monitored through riser 1 with an $\mathrm{ENRAF}^{1}$ gauge. A manual tape in riser 4 is no longer used to record waste level data, except when the other systems fail. Riser 8 contains a thermocouple tree. The interior tank photograph from 1993 shows a saltwell screen located in riser 13. Figure A2-1 is a plan view of the riser configuration. A list of tank 241-T-109 risers showing their sizes and general use is provided in Table A2-1.

A tank cross section showing the approximate waste level, along with a schematic of the tank equipment, is shown in Figure A2-2. Tank 241-T-109 has nine risers. Risers 2, 3, 4, 5, 6, and 7 are tentatively available for sampling (Lipnicki 1995). Risers 2, 3, 6, and 7, are all 30 $\mathrm{cm}$ (12 in.) in diameter. Risers 4 and 5 are $10-\mathrm{cm}$ (4 in.) in diameter. If used as sampling ports, the risers would give access to two opposite sides of the tank. Risers 2 and 4 are approximately 40 degrees counterclockwise from the inlet, and risers 5,6 , and 7 are approximately 70 degrees clockwise from the inlet.

Tank 241-T-109 has four process inlet nozzles and one cascade overflow inlet located approximately $4.8 \mathrm{~m}$ (188 in.) from the tank bottom (as measured at the tank wall). Locations are shown on Figure A2-1.

\footnotetext{
${ }^{1}$ ENRAF is a trademark of the ENRAF Corporation, Houston, Texas.
} 
Figure A2-1. Riser Configuration for Tank 241-T-109.

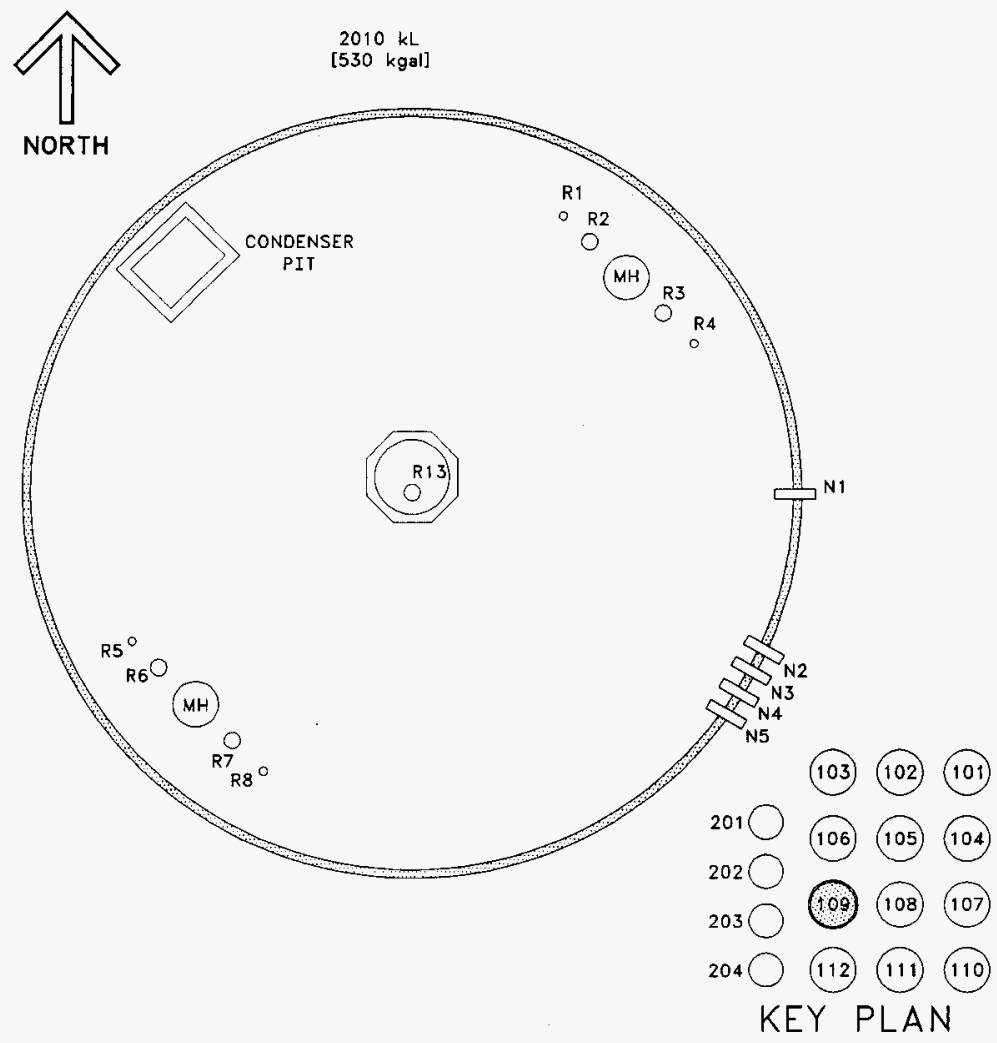


WHC-SD-WM-ER-559 Rev. 0

Table A2-1. Tank 241-T-109 Risers. ${ }^{1}$

\begin{tabular}{|c|c|c|}
\hline Homber & 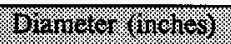 & 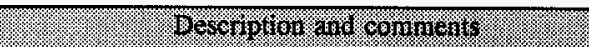 \\
\hline R1 & 4 in. & FIC, (benchmarked 12-11-86), (ENRAF 9-6-94) \\
\hline $\mathrm{R} 2$ & 12 in. & Flange with bale \\
\hline R3 & 12 in. & Breather filter \\
\hline R4 & 4 in. & Blind flange \\
\hline$\overline{\mathrm{R} 5}$ & 4 in. & Blind flange \\
\hline R6 & 12 in. & Flange \\
\hline R7 & 12 in. & Flange \\
\hline R8 & 4 in. & Thermocouple tree \\
\hline R13 & 12 in. & Saltwell riser, (benchmarked 12-11-86) \\
\hline N1 & 3 in. & Cascade inlet nozzle (from T-108) \\
\hline $\mathrm{N} 2$ & 3 in. & Process inlet nozzle \\
\hline $\bar{N} 3$ & 3 in. & Process inlet nozzle \\
\hline N4 & 3 in. & Process inlet nozzle \\
\hline N5 & 3 in. & Process inlet nozzle \\
\hline
\end{tabular}

Note:

${ }^{1}$ Alstad (1993) 
Figure A2-2. Tank 241-T-109 Cross Section and Schematic.

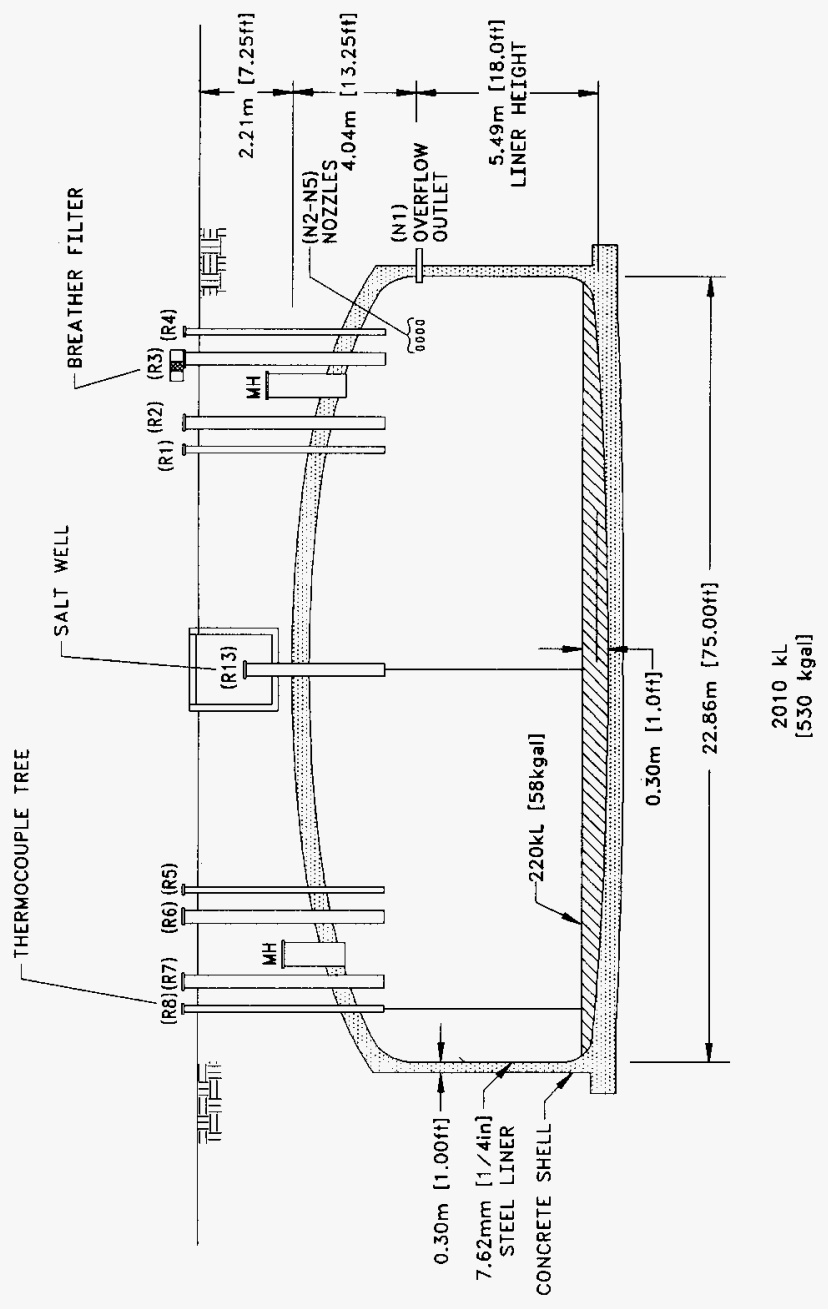




\section{A3.0 PROCESS KNOWLEDGE}

The sections below: 1) provide information about the transfer history of tank 241-T-109; 2) describe the process wastes that made up the transfers; and 3) give an estimate of the current tank contents based on transfer history.

\section{A3.1 WASTE TRANSFER HISTORY}

Table A3-1 summarizes the waste transfer history of tank 241-T-109 (Agnew et al. 1996a). Waste was initially added to tank 241-T-109 in the fourth quarter of 1945 with the cascade of first cycle decontamination waste from the bismuth phosphate process (1C)) from tank 241-T-108. Because tank 241-T-109 was the third tank in the cascade, it is unlikely that it received any 1C waste solids. In March 1946, the entire cascade series (tanks 241-T-107, 241-T-108, and 241-T-109) was declared full.

Supernatant was pumped from tank 241-T-109 to tank 241-TX-118 during the second quarter of 1951. Uranium recovery waste (UR) was intermittently cascaded from tank 241-T-108 to tank 241-T-109 from the fourth quarter of 1952 to the first quarter of 1953. Again, it is likely that all of the waste cascaded to tank 241-T-109 was liquid. During the third quarter of 1953, supernatant was transferred from tank 241-T-109 to tank 241-TX-118. During the fourth quarter of 1953 and the first quarter of 1954, tank 241-T-109 received supernatant from tank 241-TX-117. Additionally, waste (T1SltCk) was pumped from the 242-T Evaporator to tank 241-T-109 during the first quarter of 1954. The addition of T1SltCk was probably a major solids contribution to the tank even though it was a relatively low-volume transfer. There were no transfers into or out of tank 241-T-109 from the second quarter of 1954 through the third quarter of 1969.

During the fourth quarter of 1969 , supernatant was transferred from tank 241-T-109 to tank 241-TY-103. During the first and second quarters of 1973, supernatant was pumped to tank 241-T-109 from tank 241-T-108. Historical records suggest that the supernatant may have been B Plant low-level waste (BL), Battelle Northwest waste (BNW), and/or ion exchange (IX) waste. Supernatant was transferred to tank 241-T-109 from tank 241-T-111 during the second quarter of 1974. Also, during the same time period, supernatant was transferred from tank 241-T-109 to tank 241-S-110. Finally, the last major waste transfer for tank 241-T-109 involved the transfer of supernatant to tank 241-T-101 during the first quarter of 1975 and the second quarter of 1976. Saltwell liquid was pumped from tank 241-T-109 in support of tank stabilization in the third quarter of 1983. 
Table A3-1. Tank 241-T-109 Major Transfers. ${ }^{1,2}$

\begin{tabular}{|c|c|c|c|c|c|}
\hline \multirow{2}{*}{ 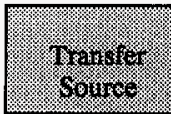 } & \multirow[b]{2}{*}{ 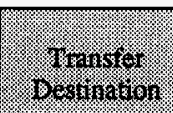 } & \multirow[b]{2}{*}{ 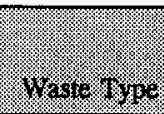 } & \multirow[b]{2}{*}{ time renod } & \multicolumn{2}{|c|}{ 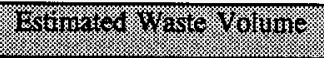 } \\
\hline & & & & $\sqrt{16 \mathrm{E}}$ & 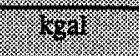 \\
\hline \multirow{2}{*}{$241-\mathrm{T}-108$} & & $1 \mathrm{C}$ & $1945-1946$ & 1,991 & 526 \\
\hline & 241-TX-118 & SU & 1951 & $-1,991$ & -526 \\
\hline \multirow[t]{2}{*}{ 241-T-108 } & & UR & $1952-1953$ & 1,995 & 527 \\
\hline & $241-\mathrm{TX}-118$ & $\mathrm{SU}$ & 1953 & $-1,687$ & -443 \\
\hline 241-TX-117 & & SU & 1953-1954 & 1,673 & 442 \\
\hline \multirow[t]{2}{*}{$242-T$} & & T1SltCk & 1954 & 49 & 13 \\
\hline & 241-TY-103 & SU & 1969 & $-1,571$ & -415 \\
\hline \multirow[t]{2}{*}{$241-T-108$} & & SU & 1973 & 1,514 & 400 \\
\hline & $241-S-110$ & $\mathrm{SU}$ & 1974 & $-1,499$ & -396 \\
\hline \multirow[t]{3}{*}{$241-T-111$} & & $\mathrm{SU}$ & 1974 & 53 & 14 \\
\hline & 241-T-101 & SU & $1975-1976$ & -220 & -58 \\
\hline & 241-AN-101 & SWLQW & 1983 & -337 & -89 \\
\hline
\end{tabular}

Notes:

1C 1st-cycle decontamination waste from the $\mathrm{BiPO}_{4}$ process (contains 10 percent of the fission products and 1 percent plutonium and often included in cladding waste).

SU Supernatant (liquid considered free of contamination to the extent it could be pumped to a crib).

SWLQW Saltwell liquid (dilute non-complexed liquid pumped from single-shell tanks to double-shell tanks).

T1SltCk Saltcake waste generated from the 242-T evaporator-crystallizer from 1951 until 1955.

UR Uranium recovery waste from uranium recovery operations (also called TBP [tri-butyl phosphate] waste).

'Agnew et al. 1996a

${ }^{2}$ Because only major transfers are listed, the sum of these transfers will not equal the current tank waste volume.

\section{A3.2 HISTORICAL ESTIMATION OF TANK CONTENTS}

This section provides an estimate of the contents of tank 241-T-109 based on historical transfer data. The historical data used for the estimate are the waste status and transaction record summary (WSTRS) (Agnew et al. 1996a), the Hanford defined waste (HDW) (Agnew et al. 1996b) list, and the tank layer model (TLM) (Agnew et al. 1996b) from the historical tank content estimate (HTCE) (Brevick et al. 1995b). The WSTRS is a compilation of available waste transfer and volume status data. The HDW provides the assumed typical 
compositions for 50 separate wastes types. In some cases, the available data are incomplete, reducing the usability of the transfer data and the modeling results derived from it. The TLM takes the WSTRS data, models the waste deposition processes, and, using additional data from the HDW (which may introduce more error), generates an estimate of the tank contents. Thus, these model predictions can only be considered estimates that require further evaluation using analytical data.

Based on Agnew et al. (1996b), tank 241-T-109 contains only a layer of $220 \mathrm{~kL}$ ( $58 \mathrm{kgal}$ ) of T1SItCk waste. Figure A3-1 shows a graphical representation of the estimated waste type and volume for the tank layer. The historical tank content estimate model predicts tank 241-T-109 to contain very large amounts of sodium, nitrate, and phosphate. Hydroxide and carbonate are also expected to be present in significant quantities. Additionally, noticeable quantities of aluminum, iron, bismuth, sulfate, nitrite, and a trace quantity of plutonium will be found. The presence of cesium and strontium will give this waste layer an activity corresponding to their concentrations. Table A3-2 shows the historical estimate of the expected waste constituents and their concentrations.

Figure A3-1. Tank Layer Model.

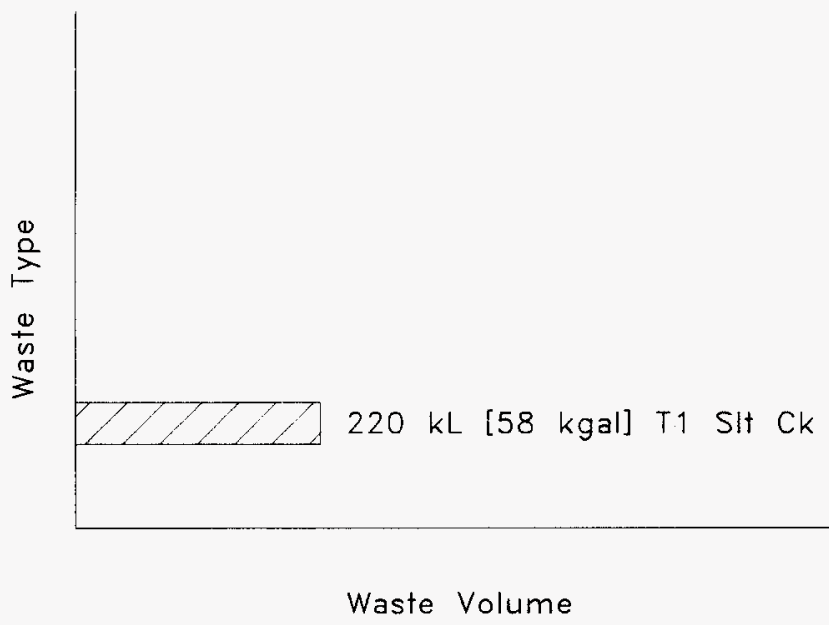


WHC-SD-WM-ER-559 Rev. 0

Table A3-2. Historical Tank Inventory Estimate. ${ }^{1,2}$ (2 sheets)

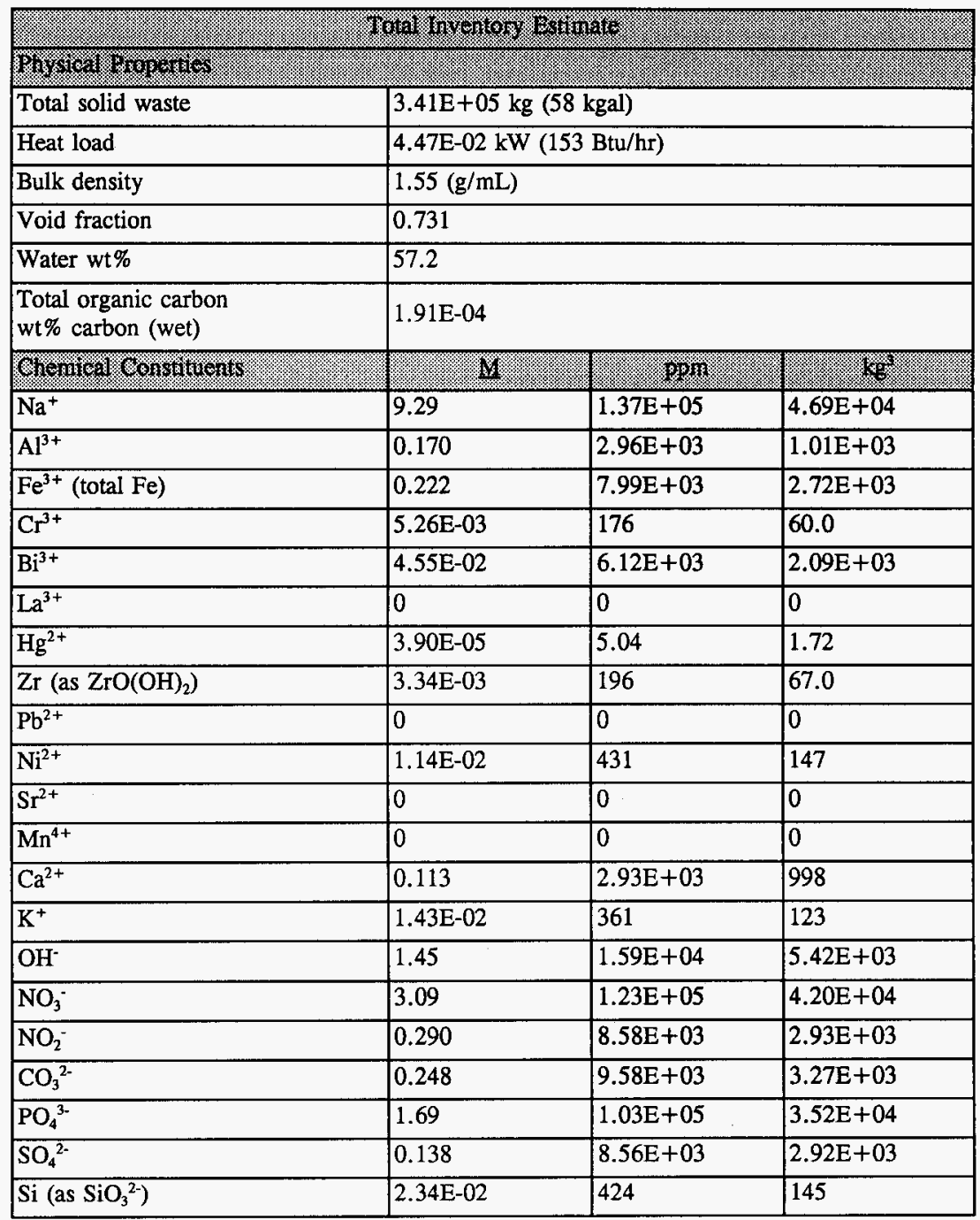


Table A3-2. Historical Tank Inventory Estimate. ${ }^{1,2}$ (2 sheets)

\begin{tabular}{|c|c|c|c|}
\hline \multicolumn{4}{|c|}{ 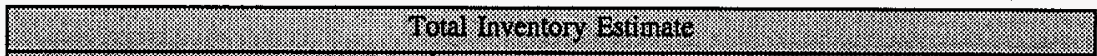 } \\
\hline 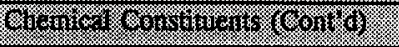 & (3) & (2.8. & 1 \\
\hline $\mathrm{F}^{-}$ & 0.146 & $1.79 \mathrm{E}+03$ & 610 \\
\hline $\mathrm{Cl}^{-}$ & $8.16 \mathrm{E}-02$ & $1.86 \mathrm{E}+03$ & 635 \\
\hline citrate & 0 & 0 & 0 \\
\hline EDTA $^{4}$ & 0 & 0 & 0 \\
\hline HEDTA $^{3-}$ & 0 & 0 & 0 \\
\hline glycolate & 0 & 0 & 0 \\
\hline acetate & 0 & 0 & 0 \\
\hline oxalate & 0 & 0 & 0 \\
\hline$\overline{\mathrm{DBP}}$ & $2.06 \mathrm{E}-05$ & 3.52 & 1.20 \\
\hline butanol & $2.06 \mathrm{E}-05$ & 0.981 & 0.335 \\
\hline $\mathrm{NH}_{3}$ & $8.99 \mathrm{E}-04$ & 9.83 & 3.35 \\
\hline $\mathrm{Fe}(\mathrm{CN})_{6}^{4-}$ & 0 & 0 & 0 \\
\hline \multicolumn{4}{|c|}{ 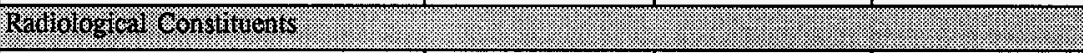 } \\
\hline $\mathrm{Pu}$ & & $1.10 \mathrm{E}-02(\mu \mathrm{Ci} / \mathrm{g})$ & $6.26(\mathrm{~kg})$ \\
\hline$\overline{\mathrm{U}}$ & $7.60 \mathrm{E}-03(\mathrm{M})$ & $1.16 \mathrm{E}+03(\mu \mathrm{g} / \mathrm{g})$ & $397(\mathrm{~kg})$ \\
\hline Cs & $1.89 \mathrm{E}-02(\mathrm{Ci} / \mathrm{L})$ & $12.2(\mu \mathrm{Ci} / \mathrm{g})$ & $4.15+03(\mathrm{Ci})$ \\
\hline $\mathrm{Sr}$ & $1.71 \mathrm{E}-03(\mathrm{Ci} / \mathrm{L})$ & $11.0(\mu \mathrm{Ci} / \mathrm{g})$ & $3.76 \mathrm{E}+03(\mathrm{Ci})$ \\
\hline
\end{tabular}

Notes:

'Agnew et al. (1996b)

${ }^{2}$ The HTCE predictions have not been validated and should be used with caution.

${ }^{3}$ Differences exist among the inventories in this column and the inventories calculated from the two sets of concentrations. 


\section{A4.0 SURVEILLANCE DATA}

Tank 241-T-109 surveillance consists of surface-level measurements (liquid and solid), temperature monitoring inside the tank (waste and headspace), and leak detection well (drywell) monitoring for radioactivity outside the tank. Surveillance data provide the basis for determining tank integrity.

Liquid-level measurements can indicate if the tank has a major leak. Solid surface-level measurements provide an indication of physical changes in and consistencies of the solid layers of a tank. Drywells located around the tank perimeter may show increased radioactivity due to leaks.

\section{A4.1 SURFACE-LEVEL READINGS}

Tank 241-T-109 is categorized as an assumed leaker. An automatic Food Instrument Corporation (FIC) gauge set in intrusion mode is used to monitor the surface level through riser 1. An ENRAF gauge has replaced the FIC gauge. Manual readings are required daily if the ENRAF gauge fails or if the computer automated surveillance system readings are zero. A manual tape in riser 4 is used to record level data only if the other systems fail. The leak detection criteria for tank 241-T-109 are an increase of $5.1 \mathrm{~cm}(2.0$ in ) or a decrease of $2.5 \mathrm{~cm}(1.0 \mathrm{in}$.) in intrusion mode from the baseline value. The criterion for a decrease does not apply to this tank. The FIC readings range from $37.9 \mathrm{~cm}(14.9 \mathrm{in}$.) to $44.3 \mathrm{~cm}(17.45 \mathrm{in}$.) and the ENRAF readings range from $46.6 \mathrm{~cm}$ (18.35 in.) to $46.9 \mathrm{~cm}$ (18.46 in.) The surface-level plot indicates a steady waste level from January 1991 to January 1994. A level history graph of the volume measurements is presented in Figure A4-1.

Tank 241-T-109 has no liquid observation well, and has six identified drywells.

\section{A4.2 INTERNAL TANK TEMPERATURES}

Tank 241-T-109 has a single thermocouple tree with 11 thermocouples to monitor the waste temperature through riser 8 . Thermocouple 1 is $36.6 \mathrm{~cm}(1.2 \mathrm{ft})$ from the bottom of the tank. Thermocouples 2 though 9 are spaced at $61-\mathrm{cm}(2-\mathrm{ft})$ intervals above thermocouple 1 .

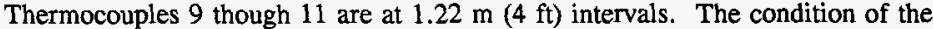
thermocouple tree, and whether it was removed or replaced, is unclear.

Only two data points are available for each thermocouple after November 1982. There are temperature data for a twelfth thermocouple, but its location is unknown and the data are not considered in this report. Non-suspect temperature data for the first eleven thermocouples 
recorded from February 1976 to February 1991 were available from the surveillance analysis computer system. Within this time span, two large breaks and several small breaks occurred in the temperature data sequence for all of the thermocouples.

The average tank temperature is $20^{\circ} \mathrm{C}\left(68^{\circ} \mathrm{F}\right)$, the minimum is $8{ }^{\circ} \mathrm{C}\left(47^{\circ} \mathrm{F}\right)$, and the maximum is $33{ }^{\circ} \mathrm{C}\left(91^{\circ} \mathrm{F}\right)$. Plots of the thermocouple readings can be found in the supporting document for the HTCE (Brevick et al. 1995a). Figure A4-2 shows a graph of the weekly high temperature.

\section{A4.3 TANK 241-T-109 PHOTOGRAPHS}

The waste in the photographs appears to have a crusted surface with varied colors ranging from tan to green, red, and dark brown. The waste in the near side of the photograph is light tan in color and appears to have a sand-like texture. The waste in the far side of the photograph is dark and appears to have a liquid surface in one small section. An old level measurement tape and other debris can be seen on the left side of the montage. An FIC probe, temperature probe, saltwell screen, manhole, and some inlet nozzles are also visible in the photographs. The photographs were taken in 1993. A photographic montage from February, 1993 may be found in Historical Tank Content Estimate for the Northwest Quadrant of the Hanford 200 West Area (Brevick et al. 1995b). The tank has been inactive since the mid 1980 s, so the photographs should accurately represent the tank interior. The $220 \mathrm{~kL}$ ( $58 \mathrm{kgal}$ ) of waste would fill the tank to a depth between $30 \mathrm{~cm}(1 \mathrm{ft})$ and $60 \mathrm{~cm}$ (2 ft). 
Figure A4-1. Tank 241-T-109 Level History.

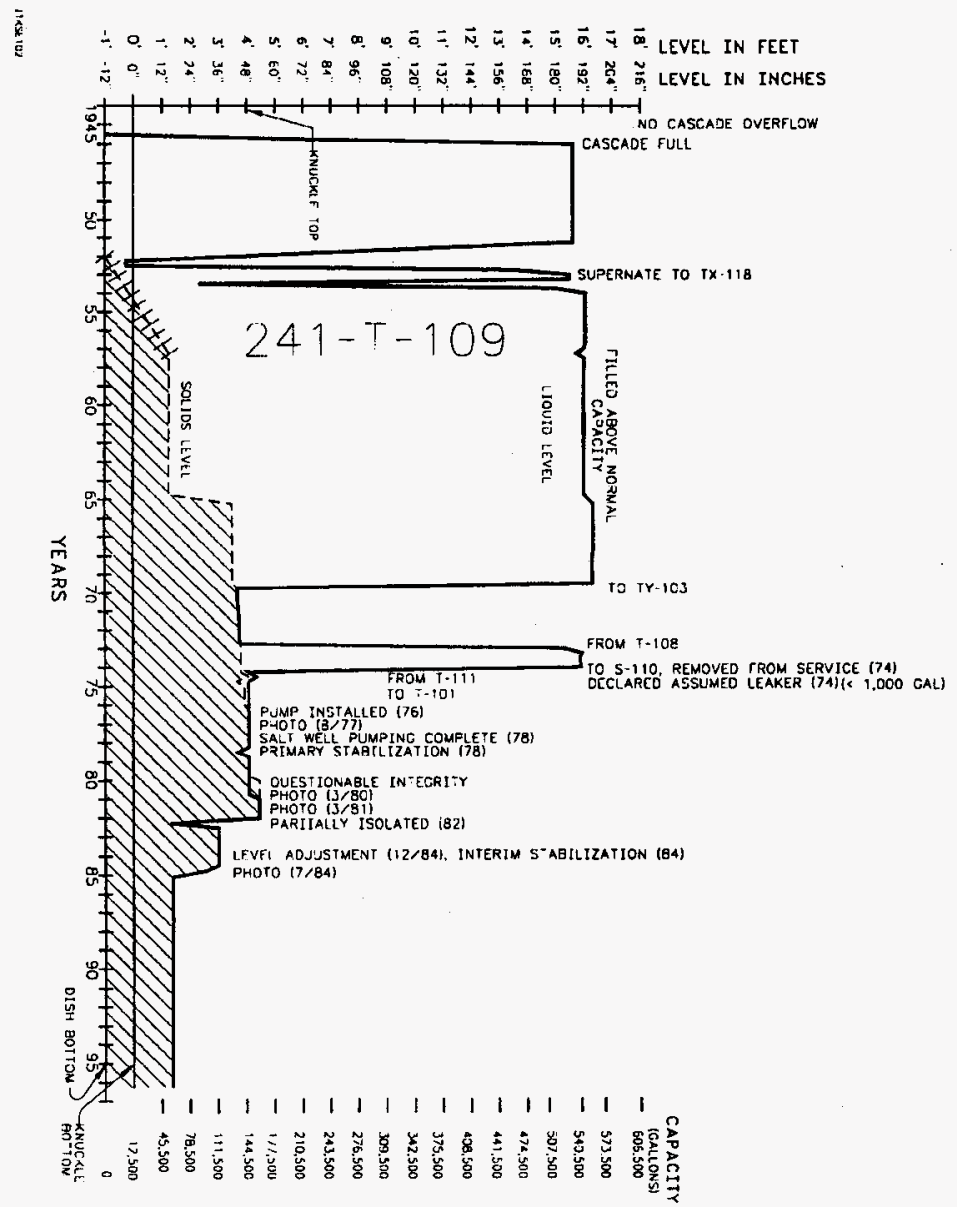


Figure A4-2. Tank 241-T-109 High Temperature Plot.

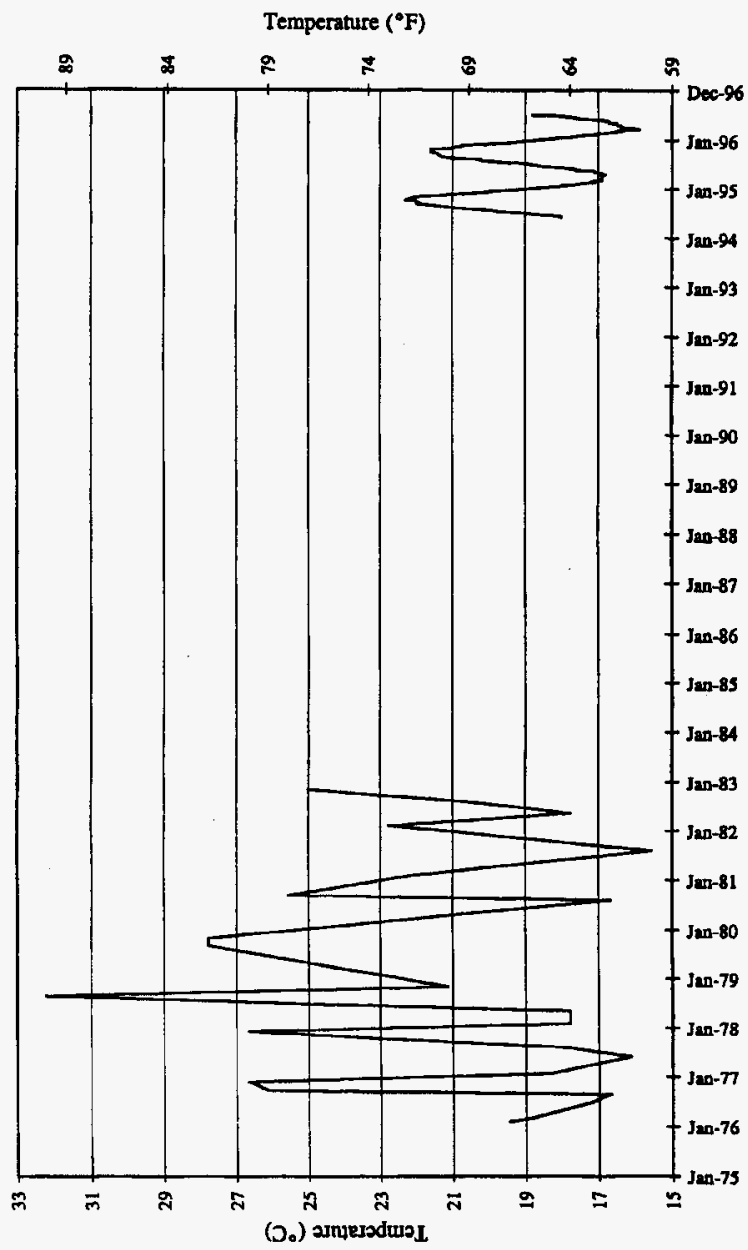




\section{A5.0 APPENDIX A REFERENCES}

Agnew, S. F., R. A. Corbin, T. B. Duran, K. A. Jurgensen, T. P. Ortiz, and B. L. Young, 1996a, Waste Status and Transaction Record Summary for the Northwest Quadrant of the Hanford 200 East Area, WHC-SD-WM-TI-669, Rev. 1, Westinghouse Hanford Company, Richland, Washington.

Agnew, S. F., J. Boyer, R. A. Corbin, T. B. Duran, J. R. Fitzpatrick, K. A. Jurgensen, T. P. Ortiz, and B. L. Young, 1996b, Hanford Tank Chemical and Radionuclide Inventories: HDW Model Rev. 3, LA-UR-96-858, Los Alamos National Laboratory, Los Alamos, New Mexico.

Alstad, A. T., 1993, Riser Configuration Document for Single-Shell Waste Tanks, WHC-SD-WM-RE-TI-053, Rev. 9, Westinghouse Hanford Company, Richland, Washington.

Brevick, C. H., L. A. Gaddis, and W. W. Pickett, 1995a, Supporting Document for the Historical Tank Content Estimate for T Tank Farm - Volume 1 and 2, WHC-SD-WM-ER-320, Rev. 0, Westinghouse Hanford Company, Richland, Washington.

Brevick, C. H., L. A. Gaddis, and E. D. Johnson, 1995b, Historical Tank Content Estimate for the Northwest Quadrant of the Hanford 200 East Areas, WHC-SD-WM-ER-351, Rev. 0, Westinghouse Hanford Company, Richland, Washington.

Hanlon, B. M., 1996, Waste Tank Summary Report for Month Ending April 30, 1996, WHC-EP-0182-97, Westinghouse Hanford Company, Richland, Washington.

Lipnicki, J., 1995, Waste Tank Risers Available for Sampling, WHC-SD-WM-TI-710, Rev. 1, Westinghouse Hanford Company, Richland, Washington.

Public Law 101-510, 1990, "Safety Measures for Waste Tanks at Hanford Nuclear Reservation," Section 3137 of National Defense Authorization Act for Fiscal Year 1991. 
WHC-SD-WM-ER-559 Rev. 0

\section{APPENDIX B}

SAMPLING OF TANK 241-T-109 
WHC-SD-WM-ER-559 Rev. 0

This page intentionally left blank. 


\section{APPENDIX B}

\section{SAMPLING OF TANK 241-T-109}

Appendix B provides sampling and analysis information for each known sampling event for tank 241-T-109 and provides an assessment of the auger sample results.

- Section B1: Tank Sampling Overview

- Section B2: Analytical Results

- Section B3: Assessment of Characterization Results

- Section B4: References for Appendix B.

Future sampling of tank 241-T-109 will be appended to the above list.

\section{B1.0 TANK SAMPLING OVERVIEW}

This section describes the August 1995 sampling and analysis events for tank 241-T-109. Auger samples were taken to satisfy the requirements of the Tank Safety Screening Data Quality Objective (Babad et al. 1995), and the Historical Model Evaluation Data Requirements (Simpson and McCain 1995). The sampling and analyses were performed in accordance with the Tank 241-T-109 Auger Sampling and Analysis Plan (Conner 1995a). The sampling and analysis plan (SAP) also instructed that if enough sample were recovered, composite material would be retained for pretreatment studies as guided in the Strategy for Sampling Hanford Site Tank Wastes for Development of Disposal Technology (Kupfer et al. 1995). Further discussions of the sampling and analysis procedures can be found in the Tank Characterization Reference Guide (DeLorenzo et al. 1994). A liquid sample was also taken from this tank in February 1974; this sample event is discussed in Section B1.4.

\section{B1.1 DESCRIPTION OF SAMPLING EVENT}

Two auger samples were collected from tank 241-T-109. Auger 95-AUG-040 was obtained on August 18 and auger 95-AUG-041 was obtained on August 21, 1995. The first auger sample was collected from riser 6 on August 18, 1995 and extruded at the 222-S Laboratory on August 24, 1995. The second auger sample was obtained from riser 2 on August 21, 1995 and extruded by the 222-S Laboratory on August 25, 1995. 
Auger sampling was used because of the depth of the waste and the expectation that a full vertical profile of the waste would be obtained. The auger samples, however, may not have recovered a full vertical profile of the waste. The waste depth was expected to be 16 to 18 in. However, because the waste sloped down from the sides to the middle, waste level readings indicated that the waste depth was 27 in. under riser 6 and 63 in. under riser 2. A memo was written stating that additional sampling may be recommended (Conner 1995b). A vertical profile is used to satisfy the safety screening data quality objective (DQO). Safety screening analyses include: total alpha to determine criticality, differential scanning calorimetry (DSC) to ascertain the fuel energy value, and thermogravimetric analysis (TGA) to obtain the total moisture content. In addition, combustible gas meter readings in the tank headspace were performed to measure flammability. The current revision of the safety screening DQO (Dukelow et al. 1995) also requires bulk density measurements. However, because the samples were taken under the previous revision of the safety screening DQO (Babad et al. 1995), bulk density was not required.

Tank 241-T-109 also was evaluated against the historical model requirements. The specified gateway analytes to evaluate the Tank Layer Model (TLM) for this tank are sodium, nitrate, fluoride, and phosphate. Historical model analyses include: DSC, TGA, inductively coupled plasma (ICP), and ion chromatography (IC). The full range of analytes is required for both ICP and IC analyses.

Sampling and analytical requirements from the safety screening and historical DQOs are summarized in Table B1-1.

Table B1-1. Integrated Data Quality Objective Requirements for Tank 241-T-109.1

\begin{tabular}{|c|c|c|c|}
\hline (6) & 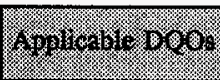 & 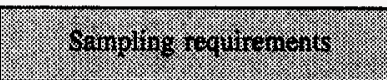 & 6) \\
\hline \multirow[t]{2}{*}{ Auger Sampling } & Safety Screening & $\begin{array}{l}\text { Core samples from a minimum } \\
\text { of two risers separated radially } \\
\text { to the maximum extent possible. }\end{array}$ & $\begin{array}{l}\text { - Energetics } \\
\text { - Moisture Content } \\
\text { - Total Alpha }\end{array}$ \\
\hline & Historical Model & $\begin{array}{l}\text { A minimum of two cores. } \\
\text { Efforts should be made to obtain } \\
\text { thick, layered segments from } \\
\text { widely separated areas of the } \\
\text { tank. }\end{array}$ & $\begin{array}{l}\text { - Energetics } \\
\text { - Moisture Content } \\
\text { - Metals } \\
\text { - Anions }\end{array}$ \\
\hline $\begin{array}{l}\text { Combustible Gas } \\
\text { Meter Reading }\end{array}$ & Safety Screening & $\begin{array}{l}\text { Measurement in a minimum of } \\
\text { one location within tank vapor } \\
\text { space. }\end{array}$ & $\begin{array}{l}\text { Flammable Gas } \\
\text { Concentration }\end{array}$ \\
\hline
\end{tabular}

Note:

'Conner 1995a 


\section{B1.2 SAMPLE HANDLING}

The riser 6 auger sample, identified as sample 95-AUG-040, had a total weight of 67.5 grams of dirty-white, crystalline solids. Most of the sample fell onto the extrusion tray when extruded at the 222-S Laboratory on August 24, 1995. The bulk of the sample appeared to come from flutes 1 to 6 at the top of the auger, with only a thin coating on the remaining flutes. The sample was homogenized and subsampled for further laboratory analyses and archiving. Due to the relatively low recovery, the sample was not divided into subsegments, but was analyzed on a whole-segment basis.

The riser 2 auger sample, identified as sample 95-AUG-041, had a total weight of 232.5 grams of solids recovered. Most of the sample fell onto the auger tray when extruded on August 25, 1995. The sample was divided into upper and lower half-segments, the upper half appearing to be gray-black crystals and the lower half appearing to be dirty white crystals. The material was homogenized and subsampled for laboratory analyses and archiving. Subsamples of each half-segment were then recombined and subsampled for composite analyses and for shipment to Pacific Northwest National Laboratory for use in pretreatment studies. Table B1-2 gives the subsampling scheme and sample description.

Table B1-2. Tank 241-T-109 Subsampling Scheme and Sample Description. ${ }^{1}$

\begin{tabular}{|c|c|c|c|c|c|}
\hline Mister & (2) & 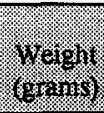 & (6) & 40 & 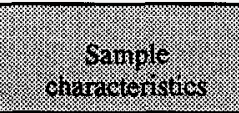 \\
\hline 6 & 95-AUG-040 & 67.5 & 16 & Whole & $\begin{array}{l}\text { Dirty-white } \\
\text { crystalline solids }\end{array}$ \\
\hline \multirow[t]{2}{*}{2} & \multirow[t]{2}{*}{ 95-AUG-041 } & \multirow[t]{2}{*}{232.5} & \multirow[t]{2}{*}{54} & Upper half & Gray-black crystals \\
\hline & & & & Lower half & Dirty-white crystals \\
\hline
\end{tabular}

Note:

${ }^{1}$ Conner $1995 \mathrm{c}$

${ }^{2}$ Sample recovery calculated using an expected sample length of $15 \mathrm{in.}$ and an estimated density of $1.55 \mathrm{~g} / \mathrm{mL}$.

\section{B1.3 SAMPLE ANALYSIS}

The analyses performed on the auger samples were limited to those required by the safety screening DQO and the historical model evaluation DQO. The analyses required by the safety screening DQO included analyses for thermal properties by DSC, moisture content by TGA, and content of fissile material by total alpha activity analysis. The historical DQO required a full set of analytes to be analyzed by IC and ICP in order to determine the presence of selected "gateway" analytes in sufficient abundance to warrant further investigation. 
Differential scanning calorimetry and TGA were performed on $8.665-\mathrm{mg}$ to $45.550-\mathrm{mg}$ samples. Quality control tests included performing the analyses in duplicate, and the use of standards. Moisture content was also measured by a gravimetric method.

Total alpha activity measurements were performed on samples that had been fused in a solution of potassium and then dissolved in acid. The resulting solution was then dried on a counting planchet and counted in an alpha proportional counter. Quality control tests included standards, spikes, blanks, and duplicate analyses.

Ion chromatography was performed on samples that had been prepared by water digestion. Quality control tests included standards, spikes, blanks, and duplicate analyses. The SAP required that the full suite of IC analytes be measured.

Inductively coupled plasma spectrometry was performed initially on samples that had been prepared by a fusion procedure, followed by dissolution in acid. Before the analyses could be completed, however, the DQO was revised to require that ICP samples be prepared by an acid digestion procedure. The reason for the change was the need to use high dilutions in the fusion procedure, resulting in higher detection limits. Quality control tests included standards, blanks, spikes, and duplicate analyses. The SAP required that the full suite of ICP elements be analyzed.

All reported analyses were performed in accordance with approved laboratory procedures. A list of the sample numbers and applicable analyses is presented in Table B1-3. The procedure numbers are presented in the discussion in Section B2.0

\section{B1.4 DESCRIPTION OF HISTORICAL SAMPLING EVENT}

Sampling data for tank 241-T-109 have been obtained for one sample obtained on February 9, 1974 and reported on March 13, 1974 (Sant 1974). The data are presented in Section B2.6. Pre-1989 analytical data have not been validated and should be used with caution.

No information was available regarding sample handling for this tank. The reason for the sampling was given as "242-Feed." The sample was reported as being a clear, amber color with no solids. 
Table B1-3. Tank 241-T-109 Sample Analysis Summary. ${ }^{1}$

\begin{tabular}{|c|c|c|c|c|}
\hline Riser: & $\begin{array}{l}\text { Sumple } \\
\text { ferentionation }\end{array}$ & S.nople portion & Samigle rumber & (3) \\
\hline \multirow[t]{4}{*}{6} & \multirow[t]{4}{*}{ 95-AUG-040 } & \multirow[t]{4}{*}{ Whole } & S95T0015972 & Gravimetric, TGA \\
\hline & & & S95T001600 & Gravimetric, DSC, TGA \\
\hline & & & S95T001612 & Total Alpha, ICP \\
\hline & & & S95T001613 & IC \\
\hline \multirow[t]{10}{*}{2} & \multirow[t]{10}{*}{ 95AUG-041 } & \multirow[t]{2}{*}{ Core composite } & S95T002176 & IC \\
\hline & & & S95T002177 & ICP \\
\hline & & \multirow[t]{4}{*}{ Upper sample } & S95T001626 2 & Gravimetric, TGA \\
\hline & & & S95T001629 & Gravimetric, DSC, TGA \\
\hline & & & S95T001630 & ICP \\
\hline & & & S95T001631 & IC \\
\hline & & \multirow[t]{4}{*}{ Lower sample } & S95T001616 ${ }^{2}$ & Gravimetric, TGA \\
\hline & & & S95T001618 & Gravimetric, DSC, TGA \\
\hline & & & S95T001619 & ICP \\
\hline & & & S95T001620 & IC \\
\hline
\end{tabular}

Note:

${ }^{1}$ Conner $1995 \mathrm{c}$

2Sample portion not homogenized prior to subsampling.

\section{B2.0 ANALYTICAL RESULTS}

\section{B2.1 OVERVIEW}

This section summarizes the sampling and analytical results associated with the August 1995 sampling and analysis of tank 241-T-109. The total alpha activity, percent water, energetics, IC, and ICP analytical results associated with this tank are presented in Table B2-1. These results are documented in Conner (1995c). 
Table B2-1. Analytical Presentation Tables.

\begin{tabular}{|l|l|}
\hline Total alpha activity & B2-2 \\
\hline Percent water & B2-3 \\
\hline Differential scanning calorimetry & B2-4 \\
\hline Summary data for metals by ICP & B2-5 through B2-41 \\
\hline Anions by IC & B2-42 through B2-49 \\
\hline
\end{tabular}

The four QC parameters assessed in conjunction with the tank 241-T-109 samples were standard recoveries, spike recoveries, duplicate analyses (RPDs), and blanks. The QC criteria specified in the SAP (Conner 1995a) were 90 to 110 percent recovery for standards and spikes and $\leq 10$ percent for RPDs. These criteria applied to all of the analytes. The only QC parameter for which limits are not specified in the SAP is blank contamination. The limits for blanks are set forth in guidelines followed by the laboratory, and all data results presented in this report have met those guidelines. Sample and duplicate pairs in which any of the QC parameters were outside of these limits are footnoted in the sample mean column of the following data summary tables with an a, b, c, d, or e as follows:

- "a" indicates that the standard recovery was below the QC limit.

- "b" indicates that the standard recovery was above the QC limit.

- "c" indicates that the spike recovery was below the QC limit.

- " $\mathrm{d}$ " indicates that the spike recovery was above the QC limit.

- " $\mathrm{e}$ " indicates that the RPD was above the QC limit.

\section{B2.2 TOTAL ALPHA ACTIVITY}

Analyses for total alpha activity were performed on the samples recovered from tank 241-T-109. The samples were prepared by fusion digestion per procedure LA-549-141, Rev. D-0 and analyzed according to procedure LA-508-101, Rev. D-2. Two fusions were prepared per sample (for duplicate results). Each fused dilution was analyzed twice, the results were averaged and reported as one value. The highest result returned was $0.00653 \mu \mathrm{Ci} / \mathrm{g}$. The sample results for total alpha are given in Table B2-2. 
Table B2-2. Tank 241-T-109 Total Alpha Activity. ${ }^{4}$

\begin{tabular}{|c|c|c|c|c|}
\hline \multirow{2}{*}{ Sarmeterningor } & \multirow[b]{2}{*}{ 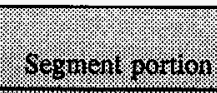 } & Result & Duplatere & samule nuzur \\
\hline & & (196ro) & (161\% & $(16,6 \%)$ \\
\hline \multirow{2}{*}{\multicolumn{5}{|c|}{ (1) }} \\
\hline & & & 0.0219 & $0.0205^{\mathrm{c}, \mathrm{e}}$ \\
\hline \multicolumn{5}{|c|}{ c05T001630 OS - } \\
\hline S95T001630 & Upper half & 0.00947 & 0.00516 & $0.00731^{c, c}$ \\
\hline S95T001619 & Lower half & 0.00623 & 0.00653 & $0.00638^{c}$ \\
\hline
\end{tabular}

Note:

${ }^{1}$ Conner 1995c

\section{B2.3 THERMODYNAMIC ANALYSES}

As required by the safety screening and historical DQOs, TGA and DSC were performed on the solids. No other physical tests were required or performed.

\section{B2.3.1 Thermogravimetric Analysis}

Thermogravimetric analysis measures the mass of a sample while its temperature is increased at a constant rate. Nitrogen is passed over the sample during heating to remove any released gases. Any decrease in the weight of a sample during TGA represents a loss of gaseous matter from the sample, either through evaporation or through a reaction that forms gas phase products. The moisture content is estimated by assuming that all TGA sample weight loss up to a certain temperature (typically 150 to 200 degrees Celsius $\left[{ }^{\circ} \mathrm{C}\right]$ ) is due to water evaporation. The temperature limit for moisture loss is chosen by the operator at an inflection point on the TGA plot. Other volatile matter fractions can often be differentiated by inflection points as well.

Tank 241-T-109 samples were analyzed by TGA using either procedure LA-514-114, Rev. C-0 on a Perkin-Elmer TGA 7 instrument, or procedure LA-560-112, Rev. B-0 on a Mettler TG 50 instrument. Auger sample AUG-95-040 (sample S95T001600) measured considerably less water than the remaining samples. However, inspection of the thermogram revealed that the weight loss curves for the sample were interpreted conservatively (first integration is only up to a slight inflection of the curves at about $105^{\circ} \mathrm{C}$ ). The second weight loss step is also integrated; if the two steps are added, the weight loss is similar to what is recorded for the other samples from this tank. Gravimetric analyses were performed for all the 241-T-109 subsamples from this tank to access the accuracy of the TGA results. Because some of the TGA results were conservatively interpreted, the gravimetric results provide a better estimate of the moisture content of the samples. Comparison of the TGA and gravimetric results is presented in Table B2-3. 
Table B2-3. Percent Water by TGA and Gravimetric Analysis. ${ }^{1}$

\begin{tabular}{|c|c|c|c|c|c|}
\hline \multirow{2}{*}{ Saminter } & \multirow{2}{*}{$\begin{array}{l}\text { Segrinent } \\
\text { lexpl }\end{array}$} & $\begin{array}{l}\text { Temperature } \\
\text { fruge? }\end{array}$ & Resillil: & Buplizare & 1, esa \\
\hline & & (1) & \% 1 $16 \%$ & 6. 10.6 & 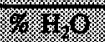 \\
\hline (1:-1: & \multicolumn{5}{|c|}{ Thernogravinetrie analysis } \\
\hline S95T001600 & \multirow[t]{2}{*}{$\begin{array}{l}\text { Whole } \\
\text { segment }\end{array}$} & $\begin{array}{l}\text { ambient to } 120 \\
\text { (ambient to } 90 \text { ) }\end{array}$ & 12.70 & 12.21 & 12.46 \\
\hline S95T0015973 & & $\begin{array}{l}\text { ambient to } 90 \\
\text { (ambient to } 100 \text { ) }\end{array}$ & 15.57 & 16.87 & 16.22 \\
\hline S95T001629 & \multirow[t]{2}{*}{ Upper half } & $\begin{array}{l}\text { ambient to } 130 \\
\text { (ambient to } 140 \text { ) }\end{array}$ & 48.87 & 49.30 & 49.08 \\
\hline S95T001626 & & $\begin{array}{l}\text { ambient to } 180 \\
\text { (ambient to } 200 \text { ) }\end{array}$ & 49.11 & 51.95 & 50.53 \\
\hline S95T001618 & \multirow[t]{2}{*}{ Lower half } & $\begin{array}{l}\text { ambient to } 120 \\
\text { (ambient to } 125 \text { ) }\end{array}$ & 39.37 & 45.76 & $42.56^{\mathrm{e}}$ \\
\hline S95T001616 & & $\begin{array}{l}\text { ambient to } 170 \\
\text { (ambient to } 170 \text { ) }\end{array}$ & 44.35 & 46.50 & 45.42 \\
\hline \multicolumn{6}{|c|}{ 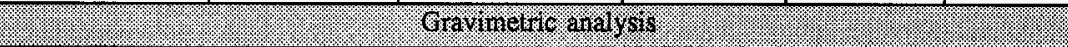 } \\
\hline S95T001600 & \multirow{2}{*}{$\begin{array}{l}\text { Whole } \\
\text { segment }\end{array}$} & $n / a$ & 47.60 & 49.30 & 48.45 \\
\hline S95T001597 & & & 50.70 & 50.40 & 50.55 \\
\hline S95T001629 & \multirow{2}{*}{ Upper half } & $n / a$ & 48.10 & 47.30 & 47.70 \\
\hline S95T001626 & & & 48.90 & 49.20 & 49.05 \\
\hline S95T001618 & \multirow[t]{2}{*}{ Lower half } & $n / a$ & 46.60 & 45.70 & 46.15 \\
\hline S95T001616 & & & 45.60 & 45.50 & 45.55 \\
\hline
\end{tabular}

Notes:

${ }^{\mathrm{I}}$ Conner $1995 \mathrm{c}$

${ }^{2}$ Temperature ranges in parentheses are for the duplicate.

${ }^{3}$ Unhomogenized sample

\section{B2.3.2 Differential Scanning Calorimetry}

In a DSC analysis, heat absorbed or emitted by a substance is measured while the temperature of the sample is heated at a constant rate. Nitrogen is passed over the sample material to remove any gases being released. The onset temperature for an endothermic or exothermic event is determined graphically. 
The DSC analyses for tank 241-T-109 were performed using either procedure LA-514-113, Rev. C- 0 on a Mettler DSC 20 instrument or procedure LA-514-114, Rev. C-0 on a Perkin-Elmer DSC 7 instrument. No exothermic reactions were noted. Therefore, an upper limit of a 95 percent confidence interval on the mean for each sample was not calculated. Transitions 1 and 2 represent endothermic events, both of which are caused by water evaporation. DSC results are presented in Table B2-4.

Table B2-4. Differential Scanning Calorimetry. ${ }^{1}$

\begin{tabular}{|c|c|c|c|c|c|c|}
\hline \multirow[b]{2}{*}{ 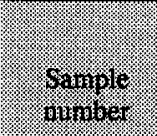 } & \multirow[b]{2}{*}{$\begin{array}{l}\text { Segratit } \\
\text { [eret? }\end{array}$} & \multirow[b]{2}{*}{ Rin } & \multicolumn{2}{|c|}{ Maristiven ? } & \multicolumn{2}{|c|}{ 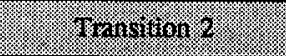 } \\
\hline & & & 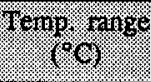 & $\begin{array}{l}411 \\
010\end{array}$ & fermo range & $\begin{array}{l}\Delta H \\
(01)\end{array}$ \\
\hline \multirow[t]{2}{*}{ S95T001600 } & \multirow{2}{*}{$\begin{array}{l}\text { Whole } \\
\text { segment }\end{array}$} & 1 & $40-145$ & 1,267 & --- & --- \\
\hline & & 2 & $38-140$ & 1,372 & $-\cdots$ & $\cdots$ \\
\hline \multirow[t]{2}{*}{ S95T001618 } & \multirow{2}{*}{$\begin{array}{l}\text { Lower } \\
\text { half }\end{array}$} & 1 & $40-155$ & 1,553 & -- & $-\cdots$ \\
\hline & & 2 & $40-158$ & 1,146 & $190-320$ & 50.0 \\
\hline \multirow[t]{2}{*}{ S95T001629 } & \multirow{2}{*}{$\begin{array}{l}\text { Upper } \\
\text { half }\end{array}$} & 1 & $20-160$ & 1,228 & $130-330$ & 52.0 \\
\hline & & 2 & $40-145$ & 1,141 & $220-340$ & 45.2 \\
\hline
\end{tabular}

Note:

'Conner $1995 \mathrm{c}$

\section{B2.4 INORGANIC ANALYSES}

The last two analyses performed on the auger samples were ICP and IC for the anions and cations respectively. In the sections below, a table is provided for each analyte.

In each table, the "Mean" column is the average of the result and duplicate values. All values, including those below the detection level (denoted by the less-than symbol, "<"), were averaged. If both sample and duplicate values were non-detected, the mean is expressed as a non-detected value. If one value were detected while the other were not, the mean is expressed as a detected value. If both values were detected, the mean is expressed as a detected value. 


\section{B2.4.1 Inductively Coupled Plasma}

Samples were prepared by either fusion or acid digests. The ICP analyses were performed per procedures LA-505-161, Rev. B-0, or LA-505-151, Rev. D-3, depending on the ICP instrument used. Although a full suite of analytes were reported, only sodium and phosphorus were specifically requested by the historical DQO. Phosphorus was analyzed as a cross-check for the phosphate results reported from IC analyses. Reports for silver, aluminum, boron, bismuth, calcium, chromium, iron manganese, lead sulfur, silicon, and zinc are above detection limits in some of the samples. The potassium and nickel results for the ICP fusion analyses (samples S95T001612, S95T001619, and S95T001630) should be disregarded, because the samples were prepared in a nickel crucible by fusion using potassium hydroxide.

The concentrations of metals in the samples are shown in Tables B2-5 through B2-41. The results from two preparation methods, fusion and acid, are presented for the metals. Composite samples shown in Tables B2-5 through B2-41 were prepared by acid digestion prior to analysis. Other samples were prepared by fusion with potassium hydroxide in a nickel crucible.

Table B2-5. Tank 241-T-109 Analytical Results: Aluminum.

\begin{tabular}{|c|c|c|c|c|c|}
\hline \multirow{2}{*}{ 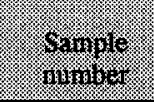 } & \multirow[b]{2}{*}{ Mriger } & \multirow[b]{2}{*}{ 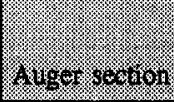 } & resesult & $842118 x 36$ & Ment \\
\hline & & & 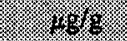 & 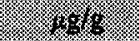 & 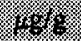 \\
\hline S95T001612 & 95-AUG-040 & Whole & 1,370 & 1,460 & 1,410 \\
\hline \$95T002177 & 95-AUG-041 & Composite & 1,410 & 1,420 & 1,420 \\
\hline S95T001630 & & Upper half & 1,430 & 833 & $1,130^{\circ}$ \\
\hline S95T001619 & & Lower half & 1,090 & 1,010 & 1,050 \\
\hline
\end{tabular}

Table B2-6. Tank 241-T-109 Analytical Results: Antimony. ${ }^{1}$

\begin{tabular}{|c|c|c|c|c|c|}
\hline \multirow{2}{*}{$\begin{array}{l}\text { Saingle } \\
\text { huniner }\end{array}$} & \multirow[b]{2}{*}{ anget } & \multirow[b]{2}{*}{ Siuger serfon } & resull & boum & Men: \\
\hline & & & 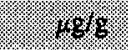 & .1068 & - 1864 \\
\hline S95T001612 & 95-AUG-040 & Whole & $<2,450$ & $<2,430$ & $<2,440$ \\
\hline S95T002177 & 95-AUG-041 & Composite & $<60.0$ & $<60.0$ & $<60.0^{n}$ \\
\hline S95T001630 & & Upper half & $<2,510$ & $<2,490$ & $<2,500^{\circ}$ \\
\hline S95T001619 & & Lower half & & & \\
\hline
\end{tabular}


Table B2-7. Tank 241-T-109 Analytical Results: Arsenic.

\begin{tabular}{|c|c|c|c|c|c|}
\hline & & $\sqrt{140}$ & Resalin & Bulvicaro & rresh \\
\hline fintor. & 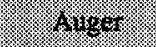 & - Section & (2) 19.8 & 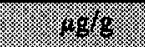 & 4.896 \\
\hline S95T001612 & 95-AUG-040 & Whole & $<613$ & $<608$ & $<610$ \\
\hline S95T002177 & \multirow[t]{3}{*}{ 95-AUG-041 } & Composite & $<100$ & $<100$ & $<100$ \\
\hline S95T001630 & & Upper half & $<629$ & $<623$ & $<626$ \\
\hline S95T001619 & & Lower half & $<565$ & $<573$ & $<569$ \\
\hline
\end{tabular}

Table B2-8. Tank 241-T-109 Analytical Results: Barium.

\begin{tabular}{|c|c|c|c|c|c|}
\hline \multirow{2}{*}{ (3) } & \multirow[b]{2}{*}{ 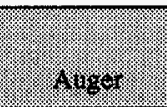 } & \multirow{2}{*}{ funger } & R-int & 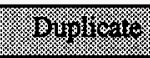 & 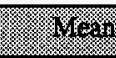 \\
\hline & & & 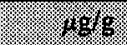 & (1) 198 & $48 \%$ \\
\hline S95T001612 & 95-AUG-040 & Whole & $<613$ & $<608$ & $<610$ \\
\hline S95T002177 & \multirow[t]{3}{*}{ 95-AUG-041 } & Composite & $<50.0$ & $<50.0$ & $<50.0$ \\
\hline S95T001630 & & Upper half & $<629$ & $<623$ & $<626$ \\
\hline S95T001619 & & Lower half & $<565$ & $<573$ & $<569$ \\
\hline
\end{tabular}

Table B2-9. Tank 241-T-109 Analytical Results: Beryllium.

\begin{tabular}{|c|c|c|c|c|c|}
\hline \multirow{2}{*}{ Sainglo } & \multirow[b]{2}{*}{40} & \multirow[b]{2}{*}{ 7.4. } & yinging & 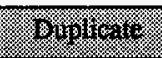 & 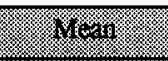 \\
\hline & & & $=48$ & . & = 1.96 \\
\hline S95T001612 & 95-AUG-040 & Whole & $<61.3$ & $<60.8$ & $<61.0$ \\
\hline S95T002177 & $95-\mathrm{AU}$ & Composite & $<5.00$ & $<5.00$ & $<5.00$ \\
\hline S95T001630 & & Upper half & $<62.9$ & $<62.3$ & $<62.6$ \\
\hline S95T001619 & & Lower half & $<56.5$ & $<57.3$ & $<56.9$ \\
\hline
\end{tabular}


Table B2-10. Tank 241-T-109 Analytical Results: Bismuth.

\begin{tabular}{|c|c|c|c|c|c|}
\hline \multirow{2}{*}{ 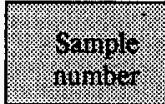 } & \multirow[b]{2}{*}{ inger } & \multirow[b]{2}{*}{ finger section } & 8 & 191910 & Ment \\
\hline & & & 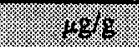 & (1) 48 & 1.838 \\
\hline S95T001612 & 95-AUG-040 & Whole & $<1,230$ & $<1,220$ & $<1,220$ \\
\hline S95T002177 & \multirow[t]{3}{*}{ 95-AUG-041 } & Composite & 181 & 158 & $170^{c}$ \\
\hline S95T001630 & & Upper half & $<1,260$ & $<1,250$ & $<1,250$ \\
\hline S95T001619 & & Lower half & $<1,130$ & $<1,150$ & $<1,140$ \\
\hline
\end{tabular}

Table B2-11. Tank 241-T-109 Analytical Results: Boron.

\begin{tabular}{|c|c|c|c|c|c|}
\hline 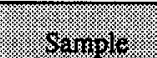 & & & Tresulu & Ol. & We \\
\hline number & inger & 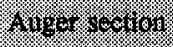 & 2) & 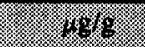 & (4):- \\
\hline S95T001612 & 95-AUG-040 & Whole & $<613$ & $<608$ & $<610$ \\
\hline S95T002177 & \multirow[t]{3}{*}{ 95-AUG-041 } & Composite & 217 & 217 & 217 \\
\hline S95T001630 & & Upper half & $<629$ & $<623$ & $<626$ \\
\hline S95T001619 & & Lower half & $<565$ & $<573$ & $<569$ \\
\hline
\end{tabular}

Table B2-12. Tank 241-T-109 Analytical Results: Cadmium.

\begin{tabular}{|c|c|c|c|c|c|}
\hline & & & Resillo & Divilicate & Mesin \\
\hline garialiey & auser & Auger secuion & 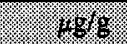 & 136 & 6 \\
\hline S95T001612 & 95-AUG-040 & Whole & $<123$ & $<122$ & $<122$ \\
\hline S95T002177 & \multirow[t]{3}{*}{ 95-AUG-041 } & Composite & $<5.00$ & $<5.00$ & $<5.00$ \\
\hline S95T001630 & & Upper half & $<126$ & $<125$ & $<125$ \\
\hline S95T001619 & & Lower half & $<113$ & $<115$ & $<114$ \\
\hline
\end{tabular}


Table B2-13. Tank 241-T-109 Analytical Results: Calcium.

\begin{tabular}{|c|c|c|c|c|c|}
\hline \multirow{2}{*}{ 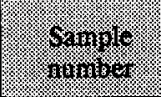 } & \multirow[b]{2}{*}{86} & \multirow[b]{2}{*}{ 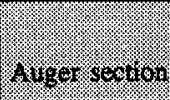 } & $\mathrm{R}=\mathbf{3}$ & 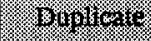 & $4 x$ \\
\hline & & & y. & 4 & 48 \\
\hline S95T001612 & 95-AUG-040 & Whole & 1,410 & 1,320 & 1,370 \\
\hline S95T002177 & 95-AUG-041 & Composite & 326 & 323 & 325 \\
\hline S95T001630 & & Upper half & $<1,260$ & $<1,250$ & $<1,250^{\circ}$ \\
\hline \$95T001619 & & Lower half & $<1,130$ & $<1,150$ & $<1,140^{\circ}$ \\
\hline
\end{tabular}

Table B2-14. Tank 241-T-109 Analytical Results: Cerium.

\begin{tabular}{|c|c|c|c|c|c|}
\hline \multirow{2}{*}{ 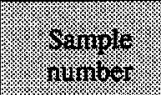 } & \multirow[b]{2}{*}{ 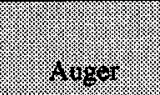 } & \multirow[b]{2}{*}{ ringer roction } & 64 & 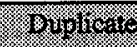 & 18\% \\
\hline & & & 40 & 1368 & 45 \\
\hline S95T001612 & 95-AUG-040 & Whole & $<1,230$ & $<1,220$ & $<1,220$ \\
\hline S95T002177 & \multirow[t]{3}{*}{ 95-AUG-041 } & Composite & $<100$ & $<100$ & $<100$ \\
\hline S95T001630 & & Upper half & $<1,260$ & $<1,250$ & $<1,250$ \\
\hline S95T001619 & & Lower half & $<1,130$ & $<1,150$ & $<1,140$ \\
\hline
\end{tabular}

Table B2-15. Tank 241-T-109 Analytical Results: Chromium.

\begin{tabular}{|c|c|c|c|c|c|}
\hline & & & resula & (O) & resin \\
\hline 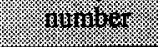 & 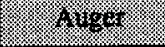 & 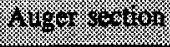 & $4 x$ & 8 & \% \\
\hline S95T001612 & 95-AUG-040 & Whole & $<123$ & $<122$ & $<122$ \\
\hline S95T002177 & \multirow[t]{3}{*}{ 95-AUG-041 } & Composite & 39.7 & 39.5 & 39.6 \\
\hline S95T001630 & & Upper half & $<126$ & $<125$ & $<125$ \\
\hline S95T001619 & & Lower half & $<113$ & $<115$ & $<114$ \\
\hline
\end{tabular}


Table B2-16. Tank 241-T-109 Analytical Results: Cobalt.

\begin{tabular}{|c|c|c|c|c|c|}
\hline \multirow{2}{*}{ (1) } & \multirow[b]{2}{*}{ 16\% } & \multirow[b]{2}{*}{$4 \cdot 4 g=28=6$ sion } & Res 3 & 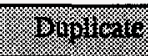 & 1.8. \\
\hline & & & 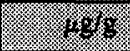 & 198 & (4) \\
\hline S95T001612 & 95-AUG-040 & Whole & $<245$ & $<243$ & $<244$ \\
\hline S95T002177 & 95-AUG-041 & Composite & $<20.0$ & $<20.0$ & $<20.0$ \\
\hline S95T001630 & & Upper half & $<251$ & $<249$ & $<250$ \\
\hline S95T001619 & & Lower half & $<226$ & $<229$ & $<228$ \\
\hline
\end{tabular}

Table B2-17. Tank 241-T-109 Analytical Results: Copper.

\begin{tabular}{|c|c|c|c|c|c|}
\hline (2) & 17 & & fissilt & 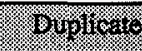 & 18ron \\
\hline number. & inge: & Ainger secton & 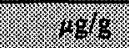 & 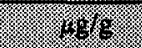 & (3.895 \\
\hline S95T001612 & 95-AUG-040 & Whole & $<123$ & $<122$ & $<122$ \\
\hline S95T002177 & \multirow[t]{3}{*}{ 95-AUG-041 } & Composite & $<10.0$ & $<10.0$ & $<10.0$ \\
\hline S95T001630 & & Upper half & $<126$ & $<125$ & $<125$ \\
\hline S95T001619 & & Lower half & $<113$ & $<115$ & $<114$ \\
\hline
\end{tabular}

Table B2-18. Tank 241-T-109 Analytical Results: Iron.

\begin{tabular}{|c|c|c|c|c|c|}
\hline \multirow{2}{*}{ 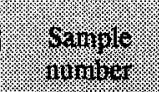 } & \multirow[b]{2}{*}{ ryser. } & \multirow[b]{2}{*}{ ingersestion } & Resulu & Siplacte & Mes.1 \\
\hline & & & .965. & . & 198:2 \\
\hline S95T001612 & 95-AUG-040 & Whole & 3,400 & 4,340 & $3,870^{c}$ \\
\hline S95T002177 & 95-AUG-041 & Composite & 15,900 & 15,900 & 15,900 \\
\hline S95T001630 & & Upper half & 14,300 & 3,900 & $9,090^{d}$ \\
\hline S95T001619 & & Lower half & 5,450 & 4,800 & $5,130^{c}$ \\
\hline
\end{tabular}


Table B2-19. Tank 241-T-109 Analytical Results: Lanthanum.

\begin{tabular}{|c|c|c|c|c|c|}
\hline \multirow{2}{*}{ Siminger } & \multirow[b]{2}{*}{ ity } & \multirow[b]{2}{*}{ 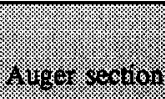 } & Restun & (3) & 11ew \\
\hline & & & 18 & (2) & $1.8 \%$ \\
\hline S95T001612 & 95-AUG-040 & Whole & $<613$ & $<608$ & $<610$ \\
\hline S95T002177 & 95-AUG-041 & Composite & $<50.0$ & $<50.0$ & $<50.0$ \\
\hline S95T001630 & & Upper half & $<629$ & $<623$ & $<626$ \\
\hline S95T001619 & & Lower half & $<565$ & $<573$ & $<569$ \\
\hline
\end{tabular}

Table B2-20. Tank 241-T-109 Analytical Results: Lead.

\begin{tabular}{|c|c|c|c|c|c|}
\hline \multirow{2}{*}{$\frac{\text { Sample }}{\text { numbor }}$} & \multirow[b]{2}{*}{ ititiger. } & \multirow[b]{2}{*}{ Auget Section } & hesiln: & 2uำ & 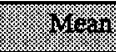 \\
\hline & & & 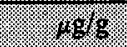 & 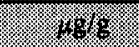 & 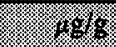 \\
\hline S95T001612 & 95-AUG-040 & Whole & $<1,230$ & $<1,220$ & $<1,220$ \\
\hline S95T002177 & \multirow[t]{3}{*}{ 95-AUG-041 } & Composite & 344 & 261 & $303^{e}$ \\
\hline S95T001630 & & Upper half & $<1,260$ & $<1,250$ & $<1,260$ \\
\hline S95T001619 & & Lower half & $<1,130$ & $<1,150$ & $<1,140$ \\
\hline
\end{tabular}

Table B2-21. Tank 241-T-109 Analytical Results: Lithium.

\begin{tabular}{|c|c|c|c|c|c|}
\hline \multirow{2}{*}{ 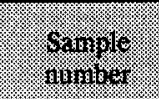 } & \multirow[b]{2}{*}{ finger } & \multirow[b]{2}{*}{4 uger secton } & resens: & 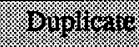 & Mesin \\
\hline & & & 1486 & 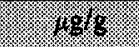 & 1.96 \\
\hline S95T001612 & 95-AUG-040 & Whole & $<123$ & $<122$ & $<122^{\circ}$ \\
\hline S95T002177 & 95-AUG-041 & Composite & $<10.0$ & $<10.0$ & $<10.0$ \\
\hline S95T001630 & & Upper half & $<126$ & $<125$ & $<125$ \\
\hline S95T001619 & & Lower half & $<113$ & $<115$ & $<114$ \\
\hline
\end{tabular}


Table B2-22. Tank 241-T-109 Analytical Results: Magnesium.

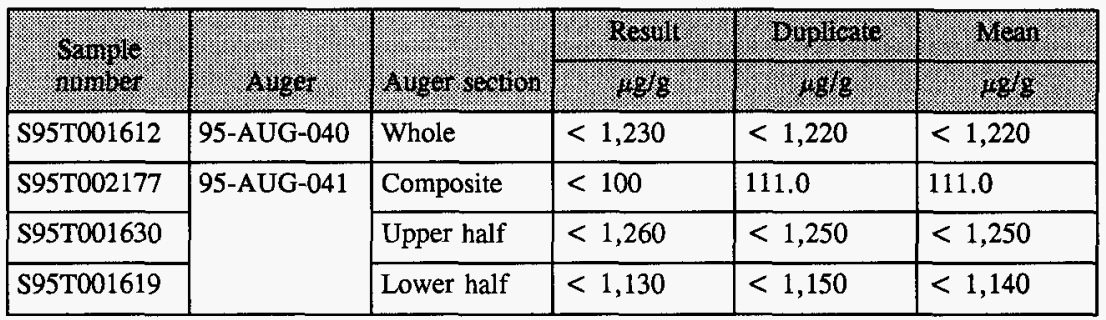

Table B2-23. Tank 241-T-109 Analytical Results: Manganese.

\begin{tabular}{|c|c|c|c|c|c|}
\hline 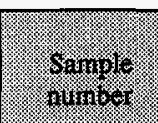 & h & 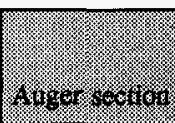 & $\int \frac{10}{10}$ & 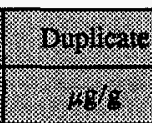 & 2. \\
\hline S95T001612 & 95-AUG-040 & Whole & 1,380 & 1,630 & $1,500^{\circ}$ \\
\hline S95T002177 & \multirow[t]{3}{*}{ 95-AUG-041 } & Composite & 1,120 & 1,110 & 1,120 \\
\hline S95T001630 & & Upper half & 754 & 493 & $\overline{624^{c}}$ \\
\hline S95T001619 & & Lower half & 555 & 423 & $489^{\circ}$ \\
\hline
\end{tabular}

Table B2-24. Tank 241-T-109 Analytical Results: Molybdenum.

\begin{tabular}{|c|c|c|c|c|c|}
\hline Ounatyo & & & ressul & Dinivicare & Nest \\
\hline nivineses & 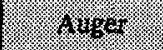 & 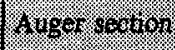 & 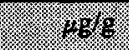 & 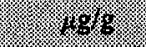 & . 196 \\
\hline S95T001612 & 95 -AUG-040 & Whole & $<613$ & $<608$ & $<610$ \\
\hline S95T002177 & \multirow[t]{3}{*}{ 95-AUG-041 } & Composite & $<50.0$ & $<50.0$ & $<50.0$ \\
\hline S95T001630 & & Upper half & $<629$ & $<623$ & $<626$ \\
\hline S95T001619 & & Lower half & $<565$ & $<573$ & $<569$ \\
\hline
\end{tabular}


Table B2-25. Tank 241-T-109 Analytical Results: Neodymium.

\begin{tabular}{|c|c|c|c|c|c|}
\hline 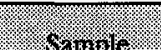 & & & Shosulu & 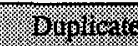 & 18 \\
\hline Gamper & when & f r nger sechion & 46y & . & 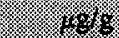 \\
\hline S95T001612 & 95-AUG-040 & Whole & $<1,230$ & $<1,220$ & $<1,220$ \\
\hline S95T002177 & \multirow[t]{3}{*}{ 95-AUG-041 } & Composite & $<100$ & $<100$ & $<100$ \\
\hline S95T001630 & & Upper half & $<1,260$ & $<1,250$ & $<1250$ \\
\hline \$95T001619 & & Lower half & $<1,130$ & $<1,150$ & $<1,140^{d}$ \\
\hline
\end{tabular}

Table B2-26. Tank 241-T-109 Analytical Results: Nickel.

\begin{tabular}{|c|c|c|c|c|c|}
\hline 6 & & & (6) & 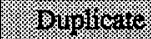 & 186. \\
\hline ninimer & 40 & 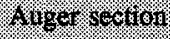 & $19 \%$ & 8.845 & (2) - \\
\hline S95T001612 & 95-AUG-040 & Whole & 2,860 & 1,670 & $2,260^{\circ}$ \\
\hline S95T002177 & \multirow[t]{3}{*}{ 95-AUG-041 } & Composite & $<20.0$ & $<20.0$ & $<20.0$ \\
\hline$\$ 95 \mathrm{~T} 001630$ & & Upper half & 4,730 & 8,450 & $6,590^{\circ}$ \\
\hline S95T001619 & & Lower half & 5,240 & 5,770 & 5,510 \\
\hline
\end{tabular}

Table B2-27. Tank 241-T-109 Analytical Results: Phosphorus.

\begin{tabular}{|c|c|c|c|c|c|}
\hline (1) & & & s. & 3. & 40 \\
\hline ining & 40 & 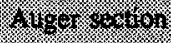 & 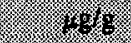 & 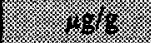 & 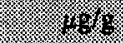 \\
\hline S95T001612 & 95-AUG-040 & Whole & 83,800 & 82,800 & 83,300 \\
\hline S95T002177 & \multirow[t]{3}{*}{ 95-AUG-041 } & Composite & 81,000 & 81,000 & $81,000^{c}$ \\
\hline \$95T001630 & & Upper half & 80,200 & 82,000 & $81,100^{d}$ \\
\hline \$95T001619 & & Lower half & 81,400 & 79,400 & $80,400^{c}$ \\
\hline
\end{tabular}


Table B2-28. Tank 241-T-109 Analytical Results: Potassium.

\begin{tabular}{|c|c|c|c|c|c|}
\hline \multirow{2}{*}{$\begin{array}{l}\text { Sampro } \\
\text { - }\end{array}$} & \multirow[b]{2}{*}{4018} & \multirow[b]{2}{*}{ 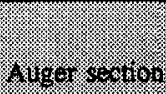 } & $28+8+4$ & 3ringluese & Mear. \\
\hline & & & $18 \%$ & 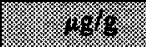 & $3=1.968$ \\
\hline S95T001612 & 95-AUG-040 & Whole & $5.22 \mathrm{E}+06$ & $\mathrm{n} / \mathrm{a}$ & $5.22 \mathrm{E}+06$ \\
\hline S95T002177 & 95-AUG-041 & Composite & $<500$ & $<500$ & $<500^{\circ}$ \\
\hline S95T001630 & & Upper half & $7.22 \mathrm{E}+06$ & $n / a$ & $7.22 \mathrm{E}+06$ \\
\hline S95T001619 & & Lower half & $7.20 \mathrm{E}+06$ & $n / a$ & $7.20 E+06$ \\
\hline
\end{tabular}

Note: $\mathbf{n} / \mathbf{a}=$ Not analyzed

Table B2-29. Tank 241-T-109 Analytical Results: Samarium.

\begin{tabular}{|c|c|c|c|c|c|}
\hline & & & resusul & 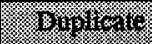 & Wesin \\
\hline 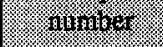 & 1) & fuger sertion & 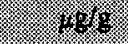 & 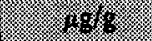 & 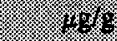 \\
\hline S95T001612 & 95-AUG-040 & Whole & $<1,230$ & $<1,220$ & $<1,220$ \\
\hline S95T002177 & \multirow[t]{3}{*}{ 95-AUG-041 } & Composite & $<100$ & $<100$ & $<100$ \\
\hline S95T001630 & & Upper half & $<1,260$ & $<1,250$ & $<1,250$ \\
\hline S95T001619 & & Lower half & $<1,130$ & $<1,150$ & $<1,140$ \\
\hline
\end{tabular}

Table B2-30. Tank 241-T-109 Analytical Results: Selenium.

\begin{tabular}{|c|c|c|c|c|c|}
\hline \multirow{2}{*}{ Sintolot: } & \multirow[b]{2}{*}{ 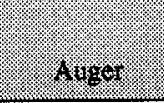 } & \multirow[b]{2}{*}{ 4anger section } & isesilu & Wujurate & 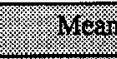 \\
\hline & & & 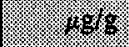 & 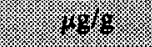 & 148 \\
\hline S95T001612 & 95-AUG-040 & Whole & $<1,230$ & $<1,220$ & $<1,220$ \\
\hline S95T002177 & \multirow[t]{3}{*}{ 95-AUG-041 } & Composite & $<100$ & $<100$ & $<100$ \\
\hline S95T001630 & & Upper half & $<1,260$ & $<1,250$ & $<1,250$ \\
\hline S95T001619 & & Lower half & $<1,130$ & $<1,150$ & $<1,140$ \\
\hline
\end{tabular}


WHC-SD-WM-ER-559 Rev. 0

Table B2-31. Tank 241-T-109 Analytical Results: Silicon.

\begin{tabular}{|c|c|c|c|c|c|}
\hline \multirow{2}{*}{ Samplo } & \multirow[b]{2}{*}{1108} & \multirow[b]{2}{*}{ inget section } & Ressin & gripucat & Meari \\
\hline & & & 1.8 .85 & $48 \%$ & 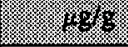 \\
\hline S95T001612 & 95-AUG-040 & Whole & 1,050 & 1,240 & $1,150^{\circ}$ \\
\hline \begin{tabular}{|l|} 
S95T002177 \\
\end{tabular} & \multirow[t]{3}{*}{ 95-AUG-041 } & Composite & 2,580 & 2,580 & $2,580^{b}$ \\
\hline S95T001630 & & Upper half & 774 & $<623$ & 774 \\
\hline S95T001619 & & Lower half & $<565$ & $<573$ & $<569$ \\
\hline
\end{tabular}

Table B2-32. Tank 241-T-109 Analytical Results: Silver.

\begin{tabular}{|c|c|c|c|c|c|}
\hline \multirow{2}{*}{ 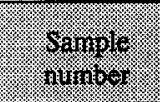 } & \multirow[b]{2}{*}{ inger } & \multirow[b]{2}{*}{ 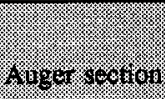 } & (2.). & 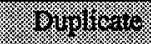 & 16rest \\
\hline & & & . & 1858 & - \\
\hline S95T001612 & 95-AUG-040 & Whole & $<123$ & $<122$ & $<122^{c}$ \\
\hline S95T002177 & 95-AUG-041 & Composite & 18.7 & 18.4 & $18.6^{\mathrm{a}, \mathrm{d}}$ \\
\hline S95T001630 & & Upper half & $<126$ & $<125$ & $<125^{\mathrm{c}}$ \\
\hline S95T001619 & & Lower half & $<113$ & $<115$ & $<114^{c}$ \\
\hline
\end{tabular}

Table B2-33. Tank 241-T-109 Analytical Results: Sodium.

\begin{tabular}{|c|c|c|c|c|c|}
\hline \multirow{2}{*}{ Gaingile } & \multirow[b]{2}{*}{. 14 wer } & \multirow[b]{2}{*}{1448} & 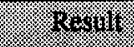 & 8.4010 & (8) \\
\hline & & & 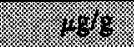 & 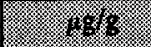 & 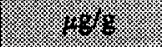 \\
\hline S95T001612 & 95-AUG-040 & Whole & $1.69 \mathrm{E}+05$ & $1.64 \mathrm{E}+05$ & $1.66 \mathrm{E}+05^{\mathrm{c}}$ \\
\hline S95T002177 & \multirow[t]{3}{*}{ 95-AUG-041 } & Composite & $1.82 \mathrm{E}+05$ & $1.84 \mathrm{E}+05$ & $1.83 \mathrm{E}+05^{\mathrm{d}}$ \\
\hline S95T001630 & & Upper half & $1.84 \mathrm{E}+05$ & $1.94 \mathrm{E}+05$ & $1.89 \mathrm{E}+05^{\mathrm{d}}$ \\
\hline S95T001619 & & Lower half & $2.03 E+05$ & $2.04 \mathrm{E}+05$ & $2.03 E+05$ \\
\hline
\end{tabular}




\begin{tabular}{|c|c|c|c|c|c|}
\hline $08 z^{\prime} z>$ & $06 z^{\prime} z>$ & $09 z^{\prime} z>$ & J[ЕЧ ІәмоТ & \multirow[b]{3}{*}{ It0-Dח $\forall-\subseteq 6$} & 619L00LS6S \\
\hline $\operatorname{oos}^{\prime} z>$ & $06 t^{\prime} z>$ & $0 \operatorname{IS}^{\prime} z>$ & נ[Еч $\lrcorner ә \mathrm{dd}_{\Omega}$ & & 0E9L00LS6S \\
\hline $002>$ & $00 z>$ & $00 z>$ & 21tsoduros & & LLIZ00LS6S \\
\hline $0 t t^{\prime} z>$ & oEt'z> & $0 s t^{6} \tau>$ & әОЧМ & 0 $0-\bigcirc \cap \forall-\varsigma 6$ & ZI9L00LS6S \\
\hline \% & tho & (3) & \multirow[t]{2}{*}{$901400 \%=074 y$} & \multirow{2}{*}{ ingur } & \multirow{2}{*}{ 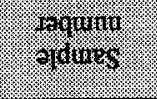 } \\
\hline 1920\% & 40.94 & 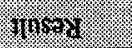 & & & \\
\hline
\end{tabular}

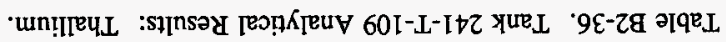

\begin{tabular}{|c|c|c|c|c|c|}
\hline tII > & SII $>$ & $\varepsilon I I>$ & IГеч دәмОТ & \multirow[b]{3}{*}{ Ito-onv- 56} & 6I9I00LS6S \\
\hline SZI $>$ & SZI $>$ & $9 Z \mathrm{I}>$ & म[eप ıədd & & 0\&9L00LS6S \\
\hline 0.0 I > & $0^{\circ} 0 \mathrm{I}>$ & $0.01>$ & 21!̣oduop & & LLIZOOLS6S \\
\hline ZZI $>$ & ZZI $>$ & $\varepsilon Z I>$ & әоОЧМ & $0+0-5 \cap \forall-\varsigma 6$ & Z19100.LS6S \\
\hline 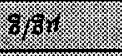 & 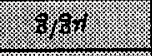 & 8 & \multirow{2}{*}{ 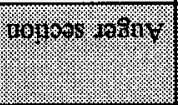 } & \multirow{2}{*}{ (19.8\%? } & \multirow{2}{*}{ 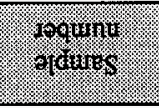 } \\
\hline 19. & 1) & 1) & & & \\
\hline
\end{tabular}

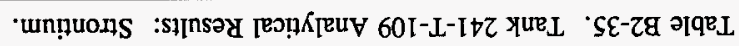

\begin{tabular}{|c|c|c|c|c|c|}
\hline $695>$ & $\mathcal{E} L \mathcal{S}>$ & s9s $>$ & ЈГеप Іәмо Т & \multirow[b]{3}{*}{ I t0-פกV-ৎ6 } & 6I9I00LS6S \\
\hline $929>$ & $\mathcal{E} 29>$ & $629>$ & I[RY Iədd $\Omega$ & & OE9I00LS6S \\
\hline $\mathcal{E} L I$ & $Z L I$ & $\mathcal{E} L \mathbf{I}$ & əิ!ฺsoduoว & & LLIZ00IS6S \\
\hline 0 I9 $>$ & $809>$ & EI9 > & әЮЧМ & $0+0-9 n v-\varsigma 6$ & ZI9I00LS6S \\
\hline 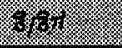 & r. & 4. & \multirow{2}{*}{ 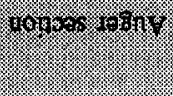 } & \multirow{2}{*}{ 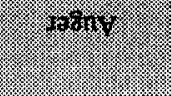 } & \multirow{2}{*}{$\frac{1}{28}$} \\
\hline 8 & 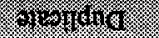 & 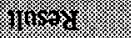 & & & \\
\hline
\end{tabular}

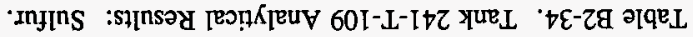


WHC-SD-WM-ER-559 Rev. 0

Table B2-37. Tank 241-T-109 Analytical Results: Titanium.

\begin{tabular}{|c|c|c|c|c|c|}
\hline & & & resinin & 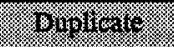 & 110 \\
\hline nimiges & 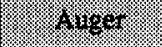 & 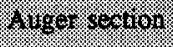 & . 469 & (2) & 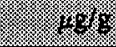 \\
\hline S95T001612 & 95-AUG-040 & Whole & $<123$ & $<122$ & $<122$ \\
\hline S95T002177 & 95-AUG-041 & Composite & $<10.0$ & $<10.0$ & $<10.0$ \\
\hline S95T001630 & & Upper half & $<126$ & $<125$ & $<125$ \\
\hline S95T001619 & & Lower half & $<113$ & $<115$ & $<114$ \\
\hline
\end{tabular}

Table B2-38. Tank 241-T-109 Analytical Results: Uranium.

\begin{tabular}{|c|c|c|c|c|c|}
\hline \multirow{2}{*}{$\begin{array}{l}\text { Sarnile } \\
\text { numbe- }\end{array}$} & \multirow[b]{2}{*}{40} & \multirow[b]{2}{*}{ a } & 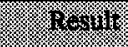 & 8.1119 .26 & 140.12 \\
\hline & & & $48 \%$ & 1398 & 4098 \\
\hline S95T001612 & 95-AUG-040 & Whole & $<4,900$ & $<4,860$ & $<4,880$ \\
\hline S95T002177 & 95-AUG-041 & Composite & $<500$ & $<500$ & $<500$ \\
\hline S95T001630 & & Upper half & $<5,030$ & $<4,980$ & $<5,010^{c}$ \\
\hline S95T001619 & & Lower half & $<4,520$ & $<4,580$ & $<4,550$ \\
\hline
\end{tabular}

Table B2-39. Tank 241-T-109 Analytical Results: Vanadium.

\begin{tabular}{|c|c|c|c|c|c|}
\hline \multirow{2}{*}{$\begin{array}{l}\text { Sumple } \\
\text { numinges }\end{array}$} & \multirow[b]{2}{*}{4} & \multirow[b]{2}{*}{ 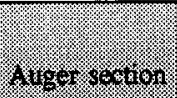 } & Kessin & Bupinere. & Year \\
\hline & & & . 1868 & 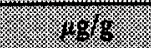 & 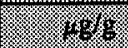 \\
\hline S95T001612 & 95-AUG-040 & Whole & $<613$ & $<608$ & $<610$ \\
\hline \begin{tabular}{|l} 
S95T002177 \\
\end{tabular} & 95-AUG-041 & Composite & $<50.0$ & $<50.0$ & $<50.0$ \\
\hline S95T001630 & & Upper half & $<629$ & $<623$ & $<626$ \\
\hline \begin{tabular}{|l} 
S95T001619 \\
\end{tabular} & & Lower half & $<565$ & $<573$ & $<569$ \\
\hline
\end{tabular}


Table B2-40. Tank 241-T-109 Analytical Results: Zinc.

\begin{tabular}{|c|c|c|c|c|c|}
\hline \multirow{2}{*}{ 6. } & \multirow[b]{2}{*}{4080} & \multirow[b]{2}{*}{$64 \mathrm{ger}$} & indulu & y) & Won \\
\hline & & & . & 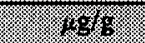 & 3y \\
\hline S95T001612 & $95-A U G-040$ & Whole & 295 & 293 & 294 \\
\hline S95T002177 & 95-AUG-041 & Composite & 48.1 & 55.9 & $52.0^{\circ}$ \\
\hline S95T001630 & & Upper half & 271 & 266 & 269 \\
\hline S95T001619 & & Lower half & 247 & 248 & 247 \\
\hline
\end{tabular}

Table B2-41. Tank 241-T-109 Analytical Results: Zirconium.

\begin{tabular}{|c|c|c|c|c|c|}
\hline \multirow{2}{*}{ 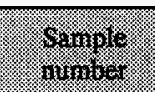 } & \multirow[b]{2}{*}{ 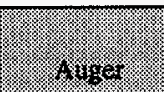 } & \multirow[b]{2}{*}{ 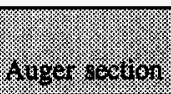 } & ingux & x) & 4 (1) \\
\hline & & & 4 & (7) & 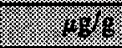 \\
\hline S95T001612 & 95-AUG-040 & Whole & $<123$ & $<122$ & $<122$ \\
\hline S95T002177 & 95-AUG-041 & Composite & 12.6 & 11.8 & 12.2 \\
\hline S95T001630 & & Upper half & $<126$ & $<125$ & $<125$ \\
\hline S95T001619 & & Lower half & $<113$ & $<115$ & $<114$ \\
\hline
\end{tabular}

\section{B2.4.2 Ion Chromatography}

Samples for ion chromatography (IC) were prepared by water digestion and performed in duplicate per procedure LA-533-105, Rev. D-1. All analytes reported by the IC instrument were requested (except for oxalate). However, only the fluoride, nitrate, and phosphate results are discussed here, as these are the only anions requested by the historical DQO for this tank. If data for other anions are to be used, the quality control criteria and raw data should be evaluated. Of the remaining IC analytes reported, only the chloride results for auger $95-A U G-040$ are above the detection limit. The concentrations of anions by IC are shown in Tables B2-42 through B2-49.

Table B2-42. Tank 241-T-109 Analytical Results: Bromide.

\begin{tabular}{|c|c|c|c|c|c|}
\hline \multirow{2}{*}{ 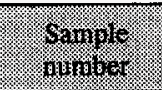 } & \multirow[b]{2}{*}{ 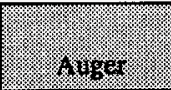 } & \multirow[b]{2}{*}{ 6148\% } & (2) & W & (1) \\
\hline & & & x & 3 & 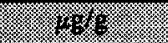 \\
\hline S95T001613 & 95-AUG-040 & Whole & $<1,300$ & $<1,300$ & $<1,300$ \\
\hline S95T002176 & 95-AUG-041 & Composite & $<563$ & $<563$ & $<563$ \\
\hline S95T001631 & & Upper half & $<1,010$ & $<1,010$ & $<1,010$ \\
\hline S95T001620 & & Lower half & $<1,100$ & $<1,100$ & $<1,100$ \\
\hline
\end{tabular}


WHC-SD-WM-ER-559 Rev. 0

Table B2-43. Tank 241-T-109 Analytical Results: Chloride.

\begin{tabular}{|c|c|c|c|c|c|}
\hline \multirow{2}{*}{ - samile } & \multirow[b]{2}{*}{ 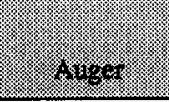 } & \multirow[b]{2}{*}{ 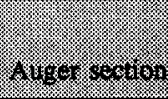 } & reseris & 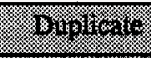 & 16and \\
\hline & & & .8 .64 & 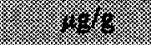 & ( \\
\hline S95T001613 & 95-AUG-040 & Whole & 578 & 569 & 574 \\
\hline S95T002176 & 95-AUG-041 & Composite & 80.9 & $<74.8$ & 80.9 \\
\hline S95T001631 & & Upper half & $<132$ & $<132$ & $<132$ \\
\hline S95T001620 & & Lower half & $<144$ & $<144$ & $<144$ \\
\hline
\end{tabular}

Table B2-44. Tank 241-T-109 Analytical Results: Fluoride.

\begin{tabular}{|c|c|c|c|c|c|}
\hline \multirow{2}{*}{ S } & \multirow[b]{2}{*}{ 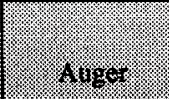 } & \multirow[b]{2}{*}{ 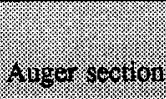 } & resurin & Bong & Men \\
\hline & & & $=1.696$ & 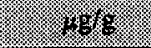 & 1.18 \\
\hline S95T001613 & 95 -AUG-040 & Whole & 961 & 682 & $822^{\mathrm{c}, \mathrm{e}}$ \\
\hline S95T002176 & 95-AUG-041 & Composite & 23,500 & 24,500 & 24,000 \\
\hline S95T001631 & & Upper half & 23,100 & 22,900 & 23,000 \\
\hline S95T001620 & & Lower half & 27,200 & 27,900 & 27,600 \\
\hline
\end{tabular}

Table B2-45. Tank 241-T-109 Analytical Results: Nitrate.

\begin{tabular}{|c|c|c|c|c|c|}
\hline 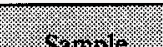 & & & Restillo & Bulnowe & Meari: \\
\hline $\ln 10$ & $4+48=$ & hinget section & 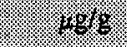 & 189 & 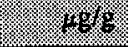 \\
\hline S95T001613 & 95-AUG-040 & Whole & 38,800 & 37,300 & 38,000 \\
\hline S95T002176 & \multirow[t]{3}{*}{ 95-AUG-041 } & Composite & 3,210 & 2,460 & $2,840^{\circ}$ \\
\hline S95T001631 & & Upper half & 3,780 & 2,970 & $3,380^{\circ}$ \\
\hline S95T001620 & & Lower half & 3,640 & 3,420 & 3,530 \\
\hline
\end{tabular}


Table B2-46. Tank 241-T-109 Analytical Results: Nitrite.

\begin{tabular}{|c|c|c|c|c|c|}
\hline (x) & & & resall & 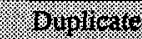 & res \\
\hline 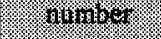 & 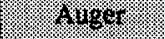 & / yutger sedilon & 46 & 49 & 1486 \\
\hline S95T001613 & 95-AUG-040 & Whole & $<113$ & $<1,130$ & $<622$ \\
\hline S95T002176 & \multirow[t]{3}{*}{ 95-AUG-041 } & Composite & $<493$ & $<493$ & $<493$ \\
\hline S95T001631 & & Upper half & $<872$ & $<872$ & $<872$ \\
\hline S95T001620 & & Lower half & $<952$ & $<952$ & $<952$ \\
\hline
\end{tabular}

Table B2-47. Tank 241-T-109 Analytical Results: Oxalate.

\begin{tabular}{|c|c|c|c|c|c|}
\hline \multirow{2}{*}{$\frac{4}{4}$} & \multirow[b]{2}{*}{$\sqrt{4}+\mathrm{g}_{\mathrm{x}}$} & \multirow[b]{2}{*}{ a } & 2 & 10.4119.6. & Won \\
\hline & & & 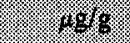 & 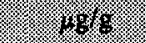 & w \\
\hline S95T002176 & \multirow[t]{3}{*}{ 95-AUG-041 } & Composite & $<468$ & $<468$ & $<468$ \\
\hline S95T001631 & & Upper half & $<791$ & $<791$ & $<791$ \\
\hline S95T001620 & & Lower half & $<863$ & $<863$ & $<863$ \\
\hline
\end{tabular}

Table B2-48. Tank 241-T-109 Analytical Results: Phosphate.

\begin{tabular}{|c|c|c|c|c|c|}
\hline \multirow{2}{*}{ 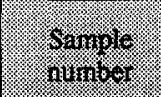 } & \multirow[b]{2}{*}{468} & \multirow[b]{2}{*}{ 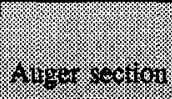 } & - & 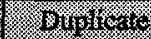 & Y \\
\hline & & & 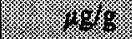 & 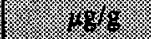 & $8 \%$ \\
\hline S95T001613 & 95-AUG-040 & Whole & $2.85 \mathrm{E}+05$ & $2.50 \mathrm{E}+05$ & $2.68 \mathrm{E}+05^{\mathrm{c}}$ \\
\hline S95T002176 & \multirow[t]{3}{*}{ 95-AUG-041 } & Composite & $2.37 \mathrm{E}+05$ & $2.38 \mathrm{E}+05$ & $2.38 \mathrm{E}+05$ \\
\hline S95T001631 & & Upper half & $2.66 \mathrm{E}+05$ & $2.71 \mathrm{E}+05$ & $2.68 \mathrm{E}+05^{\mathrm{b}}$ \\
\hline S95T001620 & & Lower half & $2.71 \mathrm{E}+05$ & $2.78 \mathrm{E}+05$ & $2.74 \mathrm{E}+05$ \\
\hline
\end{tabular}


Table B2-49. Tank 241-T-109 Analytical Results: Sulfate.

\begin{tabular}{|c|c|c|c|c|c|}
\hline \multirow{2}{*}{$\begin{array}{l}\text { sample } \\
\text { fandines. }\end{array}$} & \multirow[b]{2}{*}{ ryuser } & \multirow[b]{2}{*}{ 1.1.8et secion } & Reseral & Hilnoter & Ne:2 \\
\hline & & & 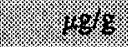 & 48 & 148 \\
\hline S95T001613 & 95-AUG-040 & Whole & $<1,400$ & $<1,400$ & $<1,400$ \\
\hline S95T002176 & 95-AUG-041 & Composite & $<604$ & $<604$ & $<604$ \\
\hline S95T001631 & & Upper half & $<1,080$ & $<1,080$ & $<1,080$ \\
\hline S95T001620 & & Lower half & $<1,180$ & $<1,180$ & $<1,180$ \\
\hline
\end{tabular}

\section{B2.5 VAPOR PHASE MEASUREMENT}

Prior to the August 18-21 auger sampling of tank 241-T-109, a vapor phase measurement was taken. Additional measurements were made on May 9, 1996. These measurements supported the safety screening DQO (Dukelow et al. 1995). The vapor phase screening was taken for flammability issues. The vapor phase measurements were taken $20 \mathrm{ft}$ below riser 6 in the dome space of the tank and results were obtained in the field (ie. no gas sample was sent to the laboratory for analysis). The results of the vapor phase measurements are provided in Table B2-50.

Table B2-50. Results of Vapor Phase Measurements of Tank 241-T-109.

\begin{tabular}{|c|c|c|}
\hline 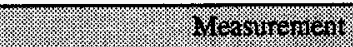 & \multicolumn{2}{|c|}{ Testil } \\
\hline & 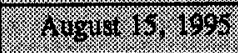 & (19.8.9.196. \\
\hline Total organic carbon (TOC) & $<1 \mathrm{ppm}$ & $1.2 \mathrm{ppm}$ \\
\hline Lower explosive limit (LEL) & $0.0 \%$ of LEL & $0.0 \%$ of LEL \\
\hline Oxygen & $21.0 \%$ & $20.8 \%$ \\
\hline Ammonia & $0 \mathrm{ppm}$ & $5 \mathrm{ppm}$ \\
\hline
\end{tabular}




\section{B2.6 HISTORICAL SAMPLE RESULTS}

The results of the February 9, 1974 sample are shown in Table B2-51. It appears that the contents of this tank were scheduled to be used as feed to the 242-S Evaporator. Because the sample was liquid and the tank has since been pumped of liquids, the sample probably does not represent present tank contents. The sample was analyzed for specific constituents and the results showed high concentrations of sodium, nitrate, and nitrite. The radionuclides tested for were cesium, cobalt, and ruthenium/rhodium. These data have not been validated and should be used with caution.

Table B2-51. Supernatant Sample.'

\begin{tabular}{|c|c|c|}
\hline W & 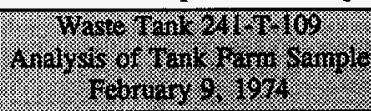 & \\
\hline (2) & 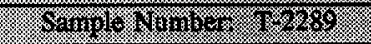 & 棸 \\
\hline 1. $9 \mathrm{mPGMVI}$ & 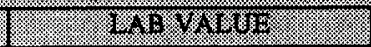 & 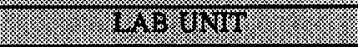 \\
\hline य: & 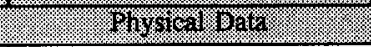 & 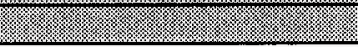 \\
\hline Sample description & \multicolumn{2}{|c|}{ Clear, amber, no solids. $300 \mathrm{mrad} / \mathrm{hr}}$. \\
\hline $\mathrm{pH}$ & 12.0 & \\
\hline Specific gravity & 1.1982 & \\
\hline Water & 77.57 & $\%$ \\
\hline \multicolumn{3}{|l|}{ 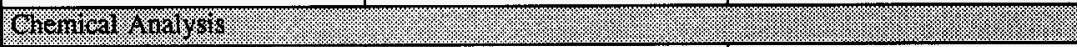 } \\
\hline $\mathrm{OH}$ & 0.384 & $\underline{\mathbf{M}}$ \\
\hline $\mathrm{Al}$ & $3.14 \mathrm{E}-02$ & $\underline{\underline{M}}$ \\
\hline $\mathrm{Na}$ & 3.74 & $\underline{\underline{M}}$ \\
\hline $\mathrm{NO}_{2}$ & 1.02 & $\underline{\underline{M}}$ \\
\hline $\mathrm{NO}_{3}$ & 0.977 & $\underline{\mathbf{M}}$ \\
\hline $\mathrm{Pu}$ & $4.70 \mathrm{E}-05$ & $\mathrm{~g} / \mathrm{L}$ \\
\hline$\overline{\mathrm{SO}_{4}}$ & 0.164 & $\underline{\mathbf{M}}$ \\
\hline $\mathrm{PO}_{4}$ & $6.24 \mathrm{E}-02$ & $\underline{\underline{\mathbf{M}}}$ \\
\hline $\mathrm{F}$ & $4.89 \mathrm{E}-02$ & $\underline{\mathbf{M}}$ \\
\hline$\overline{\mathrm{CO}_{3}}$ & 0.542 & $\underline{\underline{M}}$ \\
\hline \multicolumn{3}{|c|}{ Raciological Analysis } \\
\hline${ }^{60} \mathrm{Co}$ & $1.06 \mathrm{E}+03$ & $\mu \mathrm{Ci} / \mathrm{gal}$ \\
\hline${ }^{106} \mathrm{RuRh}$ & $1.10 \mathrm{E}+06$ & $\mu \mathrm{Ci} / \mathrm{gal}$ \\
\hline${ }^{134} \mathrm{Cs}$ & $8.36 \mathrm{E}+03$ & $\mu \mathrm{Ci} / \mathrm{gal}$ \\
\hline${ }^{137} \mathrm{Cs}$ & $6.02 \mathrm{E}+05$ & $\mu \mathrm{Ci} / \mathrm{gal}$ \\
\hline
\end{tabular}

NOTE:

'Pre-1989 analytical data have not been validated and should be used with caution. 


\section{B3.0 ASSESSMENT OF CHARACTERIZATION RESULTS}

The purpose of this chapter is to discuss the overall quality and consistency of the current sampling results for tank 241-T-109, and to present the results of the calculation of an analytical-based inventory.

This section also evaluates sampling and analysis factors that may impact interpretation of the data. These factors are used to assess the overall quality and consistency of the data and to identify any limitations in the use of the data.

\section{B3.1 FIELD OBSERVATIONS}

Sample recovery from 95-AUG-040 was quite poor as most of the waste appeared to come from the top six flutes, with just a thin coating on the remaining flutes. Recovery was much better from 95 -AUG-041, but the bottom $13 \mathrm{~cm}$ ( 5 in.) of waste may not have been recovered. This raises questions about the representativeness of the samples. Due to the crystalline nature of much of the solids recovered, it was speculated that some of the analytical variability may be caused by homogenization difficulties.

The expected depth of the waste was 16 to $18 \mathrm{in}$. However, readings taken at the risers at the time of sampling indicated $27 \mathrm{in.}$. of waste under riser 6 and 63 in. under riser 2 (Conner 1995b). In-tank photographs showed that the waste sloped down significantly from the side wall of the tank. Therefore, it appears that the full depth of the waste was not sampled and the SAP (Conner 1995a) requirement that vertical profiles of the waste be obtained from two risers was not met.

\section{B3.2 QUALITY CONTROL ASSESSMENT}

The usual quality control assessment includes an evaluation of the appropriate standard recoveries, spike recoveries, duplicate analyses, and blanks that are performed in conjunction with the chemical analyses. All the pertinent quality control tests were conducted on the 1995 auger samples, allowing a full assessment regarding the accuracy and precision of the data. The SAP (Conner 1995a) established the specific criteria for all analytes. Sample and duplicate pairs that had one or more QC results outside the specified criteria were identified by footnotes in the data summary tables.

The standard and spike recovery results provide an estimate of the accuracy of the analysis. If a standard or spike recovery is above or below the given criterion, the analytical results may be biased high or low, respectively. The precision is estimated by the relative percent difference (RPD), which is defined as the absolute value of the difference between the primary and duplicate samples, divided by their mean, times one hundred. A number of spike recoveries and RPDs were outside the target level for total alpha activity. This may 
have been caused by a high dissolved solids content on the sample mount and subsequent self-shielding. Reruns were deemed unnecessary as the sample results were far below the action limit. Some of the high RPDs for the IC analytes may be attributable to sample homogeneity problems. The two high RPDs for nitrate can be explained by the fact that the phosphate peak interferes with the resolution of the much smaller nitrate peak. The high RPD and low spike recovery for fluoride can be attributed to the fact that the fluoride peak is very near the baseline and suffers interference from the slightly larger chloride peak (Conner 1995c). Many of the ICP analytes also had one or more QC parameters outside the specified limits. The poor spike recoveries for sodium may be due to the high concentration of sodium in the samples (samples cannot be spiked to levels much greater than already present). The high concentrations of sodium required high dilutions for all ICP samples. These high dilutions in turn can cause poor or meaningless spike recoveries and RPDs for those ICP elements that had either very high concentrations or were close to the detection limit. Finally, none of the samples exceeded the criterion for preparation blanks; thus, contamination was not a problem.

In summary, the vast majority of the QC results were within the boundaries specified in the SAPs. The discrepancies mentioned here and footnoted in the data summary tables should not impact either the validity or the use of the data.

\section{B3.3 DATA CONSISTENCY CHECKS}

Comparisons of different analytical methods can help to assess the consistency and quality of the data. Several correlations were possible with the data set provided by the two core samples. Including a comparison of phosphorous as analyzed by ICP with phosphate as analyzed by IC, and a comparison of weight percent water by TGA with the weight percent water by gravimetry. In addition, mass and charge balances were calculated to help assess the overall data consistency.

\section{B3.3.1 Comparison of Results from Different Analytical Methods}

The following data consistency checks compare the results from two different analytical methods. A close correlation between the two methods strengthens the credibility of both results, whereas a poor correlation brings the reliability of the data into question. All analytical mean results were taken from tables in Section B2.0.

The analytical phosphorous mean result as determined by ICP was $80,300 \mu \mathrm{g} / \mathrm{g}$, which converts to $246,000 \mu \mathrm{g} / \mathrm{g}$ of phosphate. This compared well with the IC phosphate mean result of $269,000 \mu \mathrm{g} / \mathrm{g}$. The RPD between these two phosphate results was 8.9 percent.

The mean weight percent water result, as determined by TGA, for auger 95-AUG-041 was 45.82 percent. This compared well with the gravimetric result of 46.92 percent. The RPD between these two weight percent water results was 2.4 percent. The mean TGA result for 
auger 95-AUG-040 was 12.46 percent. This compared poorly with the gravimetric result of 48.45 percent. The RPD between these two weight percent water results was 118 percent. The large difference is attributable to the conservative manner in which the laboratory integrated the TGA raw data (Conner 1995c).

\section{B3.3.2 Mass and Charge Balance}

The principle objective in performing mass and charge balances is to determine if the measurements are self-consistent. In calculating the balances, only analytes listed in Section B2.0 detected at a concentration of $1,000 \mu \mathrm{g} / \mathrm{g}$ or greater were considered.

Except sodium, all cations listed in Table B3-1 were assumed to be in their most common hydroxide or oxide form, and the concentrations of the assumed species were calculated stoichiometrically. Because precipitates are neutral species, all positive charge was attributed to the sodium cation. The anions listed in Table B3-2 were assumed to be present as sodium salts and were expected to balance the positive charge exhibited by the cations. Phosphate, as determined by IC, is assumed to be completely water soluble and appears only in the anion mass and charge calculations. The concentrations of cationic species in Table B3-1, the anionic species in Table B3-2, and the percent water were ultimately used to calculate the mass balance.

The mass balance was calculated from the formula below. The factor 0.0001 is the conversion factor from $\mu \mathrm{g} / \mathrm{g}$ to weight percent.

$$
\begin{aligned}
\text { Mass balance }= & \% \text { Water }+0.0001 \times\{\text { Total Analyte Concentration }\} \\
= & \% \text { Water }+0.0001 \times\left\{\mathrm{Al}(\mathrm{OH})_{3}+\mathrm{FeO}(\mathrm{OH})+\mathrm{MnO}(\mathrm{OH})+\mathrm{Na}^{+}+\right. \\
& \left.\mathrm{F}^{-}+\mathrm{NO}_{3}^{-}+\mathrm{PO}_{4}^{-3}\right\}
\end{aligned}
$$

The total analyte concentrations calculated from the above equation is $498,000 \mu \mathrm{g} / \mathrm{g}$. The mean weight percent water (obtained from the gravimetric analyses reported in Table B2-3) is 47.7 percent, or $477,000 \mu \mathrm{g} / \mathrm{g}$. The mass balance resulting from adding the percent water to the total analyte concentration is 97.5 percent (Table B3-3).

The following equations demonstrate the derivation of total cations and total anions; the charge balance is the ratio of these two values.

Total cations $(\mu \mathrm{eq} / \mathrm{g})=\left[\mathrm{Na}^{+}\right] / 23.0=7,870 \mu \mathrm{eq} / \mathrm{g}$
$\underline{\text { Total anions }(\mu \mathrm{eq} / \mathrm{g})=\left[\mathrm{F}^{-}\right] / 19.0+\left[\mathrm{NO}_{3}{ }^{-}\right] / 62.0+\left[\mathrm{PO}_{4}{ }^{-3}\right] / 31.7=9,510 \mu \mathrm{eq} / \mathrm{g}}$

The charge balance obtained by dividing the sum of the positive charge by the sum of the negative charge was 0.83 . 
In summary, the above calculations yield reasonable mass and charge balance values (close to 1.00 for charge balance and 100 percent for mass balance), indicating that the analytical results are generally self-consistent.

Table B3-1. Cation Mass and Charge Data.

\begin{tabular}{|l|l|l|l|l|}
\hline Aluminum & 1,250 & $\mathrm{Al}(\mathrm{OH})_{3}$ & 3,610 & (10) \\
\hline Iron & 5,490 & $\mathrm{FeO}(\mathrm{OH})$ & 8,730 & 0 \\
\hline Manganese & 1,030 & $\mathrm{MnO}(\mathrm{OH})$ & 1,650 & 0 \\
\hline Sodium & 181,000 & $\mathrm{Na}^{+}$ & 181,000 & 0 \\
\hline Total & & 195,000 & 7,870 \\
\hline
\end{tabular}

Table B3-2. Anion Mass and Charge Data.

\begin{tabular}{|c|c|c|c|c|}
\hline 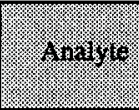 & Conceniritation & $\begin{array}{l}\text { Assimed } \\
\text { Spocted }\end{array}$ & 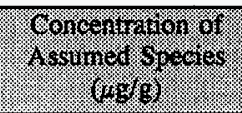 & (angrs \\
\hline Fluoride & 13,000 & $F^{-}$ & 13,000 & 684 \\
\hline Nitrate & 20,800 & $\mathrm{NO}_{3}{ }^{-}$ & 20,800 & 335 \\
\hline Phosphate & 269,000 & $\mathrm{PO}_{4}{ }^{3 \cdot}$ & 269,000 & 8,490 \\
\hline \multicolumn{3}{|l|}{ Total } & 303,000 & 9,510 \\
\hline
\end{tabular}

Table B3-3. Mass Balance Totals.

\begin{tabular}{|l|c|}
\hline & (Tis \\
\hline Total from Table B3-1 & 195,000 \\
\hline Total from Table B3-2 & 303,000 \\
\hline Water \% & 477,000 \\
\hline Grand Total & 975,000 \\
\hline
\end{tabular}




\section{B3.4 CALCULATION OF ANALYTICAL BASED MEANS AND INVENTORY}

The following evaluation was performed on the analytical data from the August 1995 auger samples for tank 241-T-109. These statistics and inventory development are used to support the characterization best-basis inventory that will be developed in Appendix D.

There were three major differences in the statistical analysis for the inventory development compared to safety screening: 1) instead of computing confidence intervals for each sub-segment mean inventory, only one confidence interval was obtained for the tank mean inventory; 2) only an inventory estimate was needed without comparing it to a threshold value; therefore, two-sided 95 percent confidence intervals on the mean inventory were computed; and 3) more analytes were analyzed for the inventory development.

The 95 percent confidence interval upper limit (UL) and lower limit (LL) on the mean for all the analytes detected are

$$
\hat{\mu}_{\mathrm{w}} \pm \mathrm{t}_{(\mathrm{a}-1,[(1+0.95) / 2])} * \sqrt{\hat{\sigma}_{\hat{\mu}}^{2}} .
$$

Where $\hat{\mu}_{\mathrm{w}}$ is a weighted sample mean, $a$ is the number of core samples, $\hat{\sigma}_{\hat{\mu}}^{2}$ is the variance of

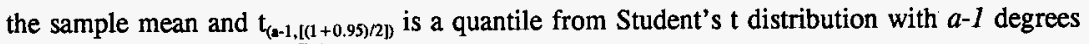
of freedom and 0.95 confidence.

The weighted sample mean $\hat{\mu}_{\mathrm{w}}$ was computed weighting the cores equally (i.e. the arithmetic means for cores 40 and 41 were computed and then those means were averaged for the weighted sample mean). For the tank $241-\mathrm{T}-109$ data, $a$ is two and $\mathrm{t}_{(1,[(1+0.95) / 2 \mathrm{D}}$ is 12.706 . The variance, $\hat{\sigma}_{\hat{\mu}}^{2}$, was estimated using restricted maximum likelihood estimation (REML) methods.

Table B3-4 gives the upper and lower limits to the 95 percent confidence intervals for analytes detected in tank 241-T-109. Some analytes had a computed lower limit less than 0 . Because an inventory estimate less than 0 is not possible, the lower limit is recorded as 0 in Table B3-4 whenever that occurred.

Table B3-4. 95\% Two-Sided Confidence Interval Limits on the Mean Concentration. (2 sheets)

\begin{tabular}{|c|c|c|c|c|}
\hline 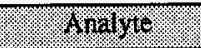 & Wx & (6) & 将\% & 14: \\
\hline Grav. $(\%)^{2}$ & 47.7 & 0.570 & 38.1 & 57.3 \\
\hline TGA $(\%)^{2}$ & 29.1 & 279 & 0.00 & 100 \\
\hline Alpha $(\mu \mathrm{Ci} / \mathrm{g})$ & 0.0137 & $4.66 \mathrm{E}-05$ & 0.00 & 0.1 \\
\hline ICP.f.Al $(\mu \mathrm{g} / \mathrm{g})$ & 1250 & 25900 & 0.00 & 3300 \\
\hline IC.F $(\mu \mathrm{g} / \mathrm{g})$ & 13000 & $1.49 \mathrm{E}+08$ & 0.00 & 168000 \\
\hline
\end{tabular}


Table B3-4. 95\% Two-Sided Confidence Interval Limits on the Mean Concentration. ( 2 sheets)

\begin{tabular}{|c|c|c|c|c|}
\hline 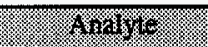 & 1. & 6\% & 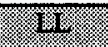 & (1) \\
\hline ICP.f.Fe $(\mu \mathrm{g} / \mathrm{g})$ & 5490 & $2.82 \mathrm{E}+06$ & 0.00 & 26800 \\
\hline ICP.f.Mn $(\mu \mathrm{g} / \mathrm{g})$ & 1030 & 225000 & 0.00 & 7060 \\
\hline ICP.f.Ni $^{1}(\mu \mathrm{g} / \mathrm{g})$ & 4160 & $3.57 \mathrm{E}+06$ & 0.00 & 28200 \\
\hline IC.NO3 $(\mu \mathrm{g} / \mathrm{g})$ & 20800 & $2.99 E+08$ & 0.00 & 241000 \\
\hline IC.PO4 $(\mu \mathrm{g} / \mathrm{g})$ & 269000 & $2.36 \mathrm{E}+07$ & 208000 & 331000 \\
\hline ICP.f.P $(\mu \mathrm{g} / \mathrm{g})$ & 82000 & $1.62 \mathrm{E}+06$ & 65800 & 98200 \\
\hline ICP.f.Na $(\mu \mathrm{g} / \mathrm{g})$ & 181000 & $2.21 \mathrm{E}+08$ & 0.00 & 370000 \\
\hline ICP.f.Zn $(\mu \mathrm{g} / \mathrm{g})$ & 276 & 323 & 47.3 & 505 \\
\hline
\end{tabular}

Note:

'Nickel crucible used

${ }^{2}$ Unhomogenized sample results not used in calculations.

Confidence intervals could not be performed on the differential scanning calorimetry (DSC) data, because all of the results were zero.

After the weighted sample means are calculated for the tank for each analyte, the sampling based inventory may be calculated. Because the analyte concentrations above are presented in terms of a mass basis concentration, the total mass of waste in the tank is needed to estimate inventories. The total mass of waste is derived from the tank volume (from surveillance) and the estimated tank bulk density (from the HTCE model). The total tank volume is $58 \mathrm{kgal}$ (or $220 \mathrm{~m}^{3}$ ) (Hanlon 1996). The density used for this estimate is $1.55 \mathrm{~g} / \mathrm{mL}$ (Agnew et al. 1996b). The total mass of waste is calculated to be 343 metric tons. Assuming that there are 343 metric tons of waste in the tank, the inventory of each of the analytes is presented in Table B3-5.

Table B3-5. Analytical-Based Inventory of Tank $241-\mathrm{T}-109 .{ }^{1}$ (2 sheets)

\begin{tabular}{|c|c|c|c|}
\hline V. & 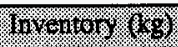 & y. & (1) \\
\hline Water & $47.7 \mathrm{wt} \%$ & $38.1 \mathrm{wt} \%$ & $57.3 \mathrm{wt} \%$ \\
\hline Aluminum & 430 & 0 & 1,100 \\
\hline Bismuth $^{3}$ & 58 & $n / a$ & $\mathrm{n} / \mathrm{a}$ \\
\hline Boron $^{3}$ & 74 & $\mathrm{n} / \mathrm{a}$ & $n / a$ \\
\hline Calcium $^{3}$ & 110 & $n / a$ & $\mathrm{n} / \mathrm{a}$ \\
\hline Chloride $^{7}$ & 120 & $\mathrm{n} / \mathrm{a}$ & $n / a$ \\
\hline Chromium $^{3}$ & 14 & $\mathrm{n} / \mathrm{a}$ & $\mathrm{n} / \mathrm{a}$ \\
\hline
\end{tabular}


WHC-SD-WM-ER-559 Rev. 0

Table B3-5. Analytical-Based Inventory of Tank 241-T-109. ${ }^{1}$ (2 sheets)

\begin{tabular}{|c|c|c|c|}
\hline 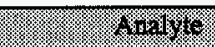 & 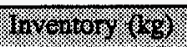 & X.ty & X1. \\
\hline Fluoride & 4,500 & 0 & 57,000 \\
\hline Iron & 1,900 & 0 & 9,100 \\
\hline Lead $^{3}$ & 100 & $\mathrm{n} / \mathrm{a}$ & $\mathrm{n} / \mathrm{a}$ \\
\hline Magnesium $^{3}$ & 38 & $\mathrm{n} / \mathrm{a}$ & $\mathrm{n} / \mathrm{a}$ \\
\hline Manganese & 350 & 0 & 2,400 \\
\hline Nitrite $^{6}$ & 170 & $\mathrm{n} / \mathrm{a}$ & $\mathrm{n} / \mathrm{a}$ \\
\hline Nitrate & 7,100 & 0 & 82,000 \\
\hline Phosphate $^{4}$ & 92,000 & 71,000 & 110,000 \\
\hline Silicon $^{7}$ & 300 & $\mathrm{n} / \mathrm{a}$ & $n / a$ \\
\hline Silver $^{3}$ & 6 & $\mathrm{n} / \mathrm{a}$ & $\mathrm{n} / \mathrm{a}$ \\
\hline Sodium & 62,000 & 0 & 130,000 \\
\hline Sulfate $^{3,5}$ & 180 & $\mathrm{n} / \mathrm{a}$ & $\mathrm{n} / \mathrm{a}$ \\
\hline Zinc & 94 & 16 & 170 \\
\hline Zirconium $^{3}$ & 4 & $\mathrm{n} / \mathrm{a}$ & $\mathrm{n} / \mathrm{a}$ \\
\hline Total Alpha & $4.67 \mathrm{Ci}$ & 0 & 34.1 \\
\hline
\end{tabular}

Notes:

$\mathbf{n} / \mathbf{a}=$ Not applicable

'The bulk density used to calculate inventory was not measured; it is an estimate from

Agnew et al. (1996b).

${ }^{2} 95$ percent two-sided confidence interval upper and lower limits.

${ }^{3}$ These analytes were measured using acid digestion on the composite of 95-AUG-041. Because only one sample was available, the mean and upper and lower limits were not calculated.

${ }^{4}$ Assume that all phosphorus is in the form of phosphate.

${ }^{5}$ Sulfate was not detected using IC, but sulfur was measured using ICP (acid digestion only). All sulphur is assumed to be sulfate.

'All nitrate results were below detection limits. Lowest detection limit value was used to estimate inventory.

${ }^{7}$ The concentration used to estimate the inventory was a weighted mean. The weighted mean was calculated using both measured concentrations and detection limits. Silicon calculations used fusion digest results only. 


\section{B4.0 APPENDIX B REFERENCES}

Babad, H., J. W. Hunt, and K. S. Redus, 1995, Tank Safety Screening Data Quality Objective, WHC-SD-WM-SP-004, Rev. 1, Westinghouse Hanford Company, Richland, Washington.

Brevick, C. H., L. A. Gaddis, and E. D. Johnson, 1995, Historical Tank Content Estimate for the Northwest Quadrant of the Hanford 200 East Areas, WHC-SD-WM-ER-351, Rev. 0, Westinghouse Hanford Company, Richland, Washington.

Conner, J. M., 1995a, Tank 241-T-109 Auger Sampling and Analysis Plan, WHC-SD-WM-TSAP-014, Rev. 0-A, Westinghouse Hanford Company, Richland, Washington.

Conner, J. M., 1995b, "Need Identified to Resample Tank 241-T-109," (Internal Memo 75310-95-9-098, to T. J. Kelley, October 24) Westinghouse Hanford Company, Richland, Washington.

Conner, J. M., 1995c, Final Report for Tank 241-T-109, Auger Samples 95-AUG-040 and 95-AUG-041, WHC-SD-WM-DP-144, Rev.1A, Westinghouse Hanford Company, Richland, Washington.

DeLorenzo, D. S., J. H. Rutherford, D. J. Smith, D. B. Hiller, K. W. Johnson, and B. C. Simpson, 1994, Tank Characterization Reference Guide, WHC-SD-WM-TI-648, Rev. 0, Westinghouse Hanford Company, Richland, Washington.

Dukelow, G. T., J. W. Hunt, H. Babad, and J. E Meacham, 1995, Tank Safety Screening Data Quality Objective, WHC-SD-WM-SP-004, Rev. 2, Westinghouse Hanford Company, Richland, Washington.

Hanlon, B. M., 1996, Waste Tank Summary Report for the Month Ending April 30, 1995, WHC-EP-0182-97, Westinghouse Hanford Company, Richland, Washington.

Kupfer, M. J., W. W. Schulz, and J. T. Slankas, 1995, Strategy for Sampling Hanford Site Tank Wastes for Development of Disposal Technology, WHC-SD-WM-TA-154, Rev. 1, Westinghouse Hanford Company, Richland, Washington.

Sant, W. H., 1974, Analysis of Tank Farm Samples, Sample: T-2289, Tank 109-T, (internal memorandum to R. L. Walser, March 13), Atlantic Richfield Hanford Company, Richland, Washington.

Simpson, B. C., and D. J. McCain, 1995, Historical Model Evaluation Data Requirements, WHC-SD-WM-DQO-118, Rev. 0-A, Westinghouse Hanford Company, Richland, Washington. 
WHC-SD-WM-ER-559 Rev. 0

APPENDIX C

STATISTICAL ANALYSIS FOR ISSUE RESOLUTION 
WHC-SD-WM-ER-559 Rev. 0

This page intentionally left blank. 


\section{APPENDIX C \\ STATISTICAL ANALYSIS FOR ISSUE RESOLUTION}

In appendix $\mathrm{C}$, the analyses required for the applicable data quality objective (DQO) reports for tank 241-T-109 are performed. Specifically, statistical and other numerical manipulations required in the DQO reports are performed and documented in this appendix. The two analyses required for tank 241-T-109 are documented in the following sections:

- Section C1: Statistical analysis supporting the Safety Screening DQO (Dukelow et al. 1995). Specifically, confidence intervals were needed to support the plutonium (criticality) threshold limit.

- Section C2: Gateway analysis supporting the Historical Model Evaluation Data Requirements DQO (Simpson and McCain 1995).

- Section C3: References for Appendix C.

\section{C1.0 STATISTICS FOR SAFETY SCREENING DQO}

The safety screening DQO (Dukelow et al. 1995) defines acceptable decision confidence limits in terms of one-sided 95 percent confidence intervals on the mean for each subsample. In this appendix, one sided confidence limits supporting the safety screening DQO are calculated for tank 241-T-109. All data considered in this section are taken from the final laboratory data package for the 1995 auger sampling event for tank 241-T-109 (Conner 1995).

Confidence intervals were computed for each sample number from tank 241-T-109 analytical data. The sample numbers and confidence intervals are provided in Table C1-1.

The upper limit (UL) of a one-sided 95 percent confidence interval for the mean is

$$
\hat{\mu}+t_{(n-1,0.95)} * \sqrt{\frac{\hat{\sigma}^{2}}{n}} .
$$

where $\hat{\mu}$ is the arithmetic mean of the data, $n$ is the number of observations, $\hat{\sigma}^{2}$ is the estimate of the variance of the data, and $t_{(0-1,0.09)}$ is a quantile from Student's $t$ distribution with $n-1$ degrees of freedom and 0.95 confidence. 
For the tank 241-T-109 data (per sample number), $n$ is two and $t_{(1,0.95)}$ is 6.314 .

The upper limit of the 95 percent confidence interval for each sample number based on the total alpha data is listed in Table C1-1. Each confidence interval can be used to make the following statement. If the upper limit is less than $40 \mu \mathrm{Ci} / \mathrm{g}$, then one would reject the null hypothesis that the total alpha is greater than or equal to $40 \mu \mathrm{Ci} / \mathrm{g}$ at the 0.05 level of significance. The upper limit of $40 \mu \mathrm{Ci} / \mathrm{g}$ was calculated from the $1 \mathrm{~g} / \mathrm{L}$ plutonium limit assuming a density of $1.55 \mathrm{~g} / \mathrm{mL}$ (Agnew et al. 1996) and assuming that all the plutonium is ${ }^{239} \mathrm{Pu}$.

Table C1-1. 95 Percent Confidence Interval Upper Limits for Total Alpha for Tank 241-T-109.

\begin{tabular}{|c|c|c|c|c|c|}
\hline Samer & 10.84 & 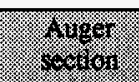 & 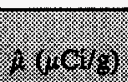 & 08 & wit \\
\hline $95 \mathrm{~T} 001612$ & 95 -AUG-040 & Whole & $2.05 \mathrm{E}-02$ & $1.96 \mathrm{E}-06$ & $2.93 \mathrm{E}-02$ \\
\hline $95 \mathrm{~T} 001619$ & 95-AUG-041 & Lower half & $7.32 \mathrm{E}-03$ & $4.64 \mathrm{E}-06$ & $2.09 \mathrm{E}-02$ \\
\hline $95 \mathrm{~T} 001630$ & 95-AUG-041 & Upper half & $6.38 \mathrm{E}-03$ & $2.25 \mathrm{E}-08$ & $7.33 \mathrm{E}-03$ \\
\hline
\end{tabular}

Notes:

AUG $=$ Auger

$\mathrm{UL}=$ Upper limit

Confidence intervals were not performed on the differential scanning calorimetry (DSC) data, because all of the results were zero.

\section{C2.0 GATEWAY ANALYSIS FOR HISTORICAL MODEL DQO}

The Historical Model Evaluation Data Requirements (Simpson and McCain 1995) requires that a gateway analysis be performed on the analytical data obtained from tank 241-T-109. The purpose of the gateway analysis is to provide a quick screening check of the analytical data before a more thorough set of analyses are performed on the tank. If the gateway analysis fails, then the remainder of the analyses in the historical DQO will not be performed. The historical gateway analysis consists of two parts, both of which are described below. All data considered in this section are taken from the final laboratory data package for the 1995 auger sampling event for tank 241-T-109 (Conner 1995).

The first part of the gateway analysis is to check if the sum of the mass of a set group of analytes (indicator analytes) contributes over 85 percent of the total tank waste mass. The indicator analytes for tank 241-T-109 are water, sodium, nitrate, phosphate, and fluoride. 
The gateway analysis will be performed for three samples: 95-AUG-040, 95-AUG-041 upper half, and 95-AUG-041 lower half. The results of this analysis are shown in Table C2-1. The first part of the gateway analysis passed for all samples.

Table C2-1. Part 1 of Gateway Analysis.

\begin{tabular}{|c|c|c|c|}
\hline 8 & $\begin{array}{l}\text { Sh } \\
\text { Whore sample }\end{array}$ & 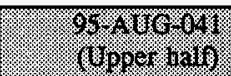 & 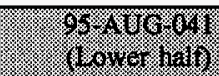 \\
\hline Water \% & 48.5 & 47.7 & 46.2 \\
\hline Sodium \% & 16.6 & 18.9 & 20.4 \\
\hline Nitrate \% & 3.8 & 0.34 & 0.35 \\
\hline Phosphate \% & 26.8 & 26.9 & 27.5 \\
\hline Fluoride \% & 0.08 & 2.3 & 2.8 \\
\hline Sum (\%) & 95.7 & 96.1 & 97.06 \\
\hline Pass/fail & Pass & Pass & Pass \\
\hline
\end{tabular}

The second part of the gateway analysis requires that each of the indicator analytes (used above) be compared to the value predicted by the historical model. For the second part of the gateway analysis to pass, each of the indicator analytes measured from sampling has to be greater than 10 percent of the value predicted by the model. Table C2-2 summarizes the results of this analysis. The second part of the gateway analysis failed for every sample. However, it should be noted that averaging the results of the two auger samples gives results which would have passed this part of the gateway analysis.

Table C2-2. Part 2 of Gateway Analysis.

\begin{tabular}{|c|c|c|c|c|c|}
\hline & 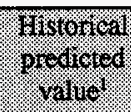 & 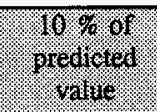 & Whos & 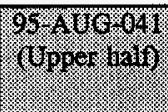 & 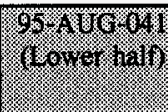 \\
\hline Water \% & 36.1 & 3.61 & 48.5 & 47.7 & 46.2 \\
\hline Sodium \% & 14.4 & 1.44 & 16.6 & 18.9 & 20.4 \\
\hline Nitrate \% & 8.6 & 0.86 & 3.8 & 0.34 & 0.35 \\
\hline Phosphate \% & 9.6 & 0.96 & 26.8 & 26.9 & 27.5 \\
\hline Fluoride \% & 1.1 & 0.11 & 0.08 & 2.3 & 2.8 \\
\hline Pass/fail & $n / a$ & $n / a$ & Fail (Fluoride) & Fail (Nitrate) & Fail (Nitrate) \\
\hline
\end{tabular}

Note:

'Simpson and McCain (1995) 
Because the gateway analysis passed part 1 but failed part 2, the analysis is considered to have failed for tank 241-T-109. This means that the remainder of the historical DQO analysis will not be applied to the tank.

\section{C3.0 APPENDIX C REFERENCES}

Agnew, S. F., J. Boyer, R. A. Corbin, T. B. Duran, J. R. Fitzpatrick, K. A. Jurgensen, T. P. Ortiz, and B. L. Young, 1996, Hanford Tank Chemical and Radionuclide Inventories: HDW Model Rev. 3, LA-UR-96-858, Los Alamos National Laboratory, New Mexico.

Conner, J. M., 1995, Final Report for Tank 241-T-109, Auger Samples 95-AUG-040 and 95-AUG-041, WHC-SD-WM-DP-144, Rev. 1-A, Westinghouse Hanford Company, Richland, Washington.

Dukelow, G. T., J. W. Hunt, H. Babad, and J. E Meacham, 1995, Tank Safety Screening Data Quality Objective, WHC-SD-WM-SP-004, Rev. 2, Westinghouse Hanford Company, Richland, Washington.

Simpson, B. C., and D. J. McCain, 1995, Historical Model Evaluation Data Requirements, WHC-SD-WM-DQO-118, Rev. 0-A, Westinghouse Hanford Company, Richland, Washington. 
WHC-SD-WM-ER-559 Rev. 0

APPENDIX D

EVALUATION TO ESTABLISH BEST-BASIS

INVENTORY FOR TANK 241-T-109

D-1 
WHC-SD-WM-ER-559 Rev. 0

This page intentionally left blank. 


\section{APPENDIX D}

\section{EVALUATION TO ESTABLISH BEST-BASIS \\ INVENTORY FOR TANK 241-T-109}

An effort is underway to provide waste inventory estimates that will serve as standard characterization source terms for the various waste management activities (Kupfer et al. 1995). As part of this effort, an evaluation of available chemical information for tank 241-T-109 was performed, and a best-basis inventory was established. This work, detailed in the following sections, follows the methodology that was established by the standard inventory task.

\section{D1.0 CHEMICAL INFORMATION SOURCES}

Available chemical information for tank 241-T-109 included:

- Data from recent analyses of two auger samples that were collected in August, 1995 (Conner 1995). See Appendix B, Section B2.0 for data.

- Data from the analysis of supernatant sample T-2289 collected in 1974 (Sant 1974). See Appendix B, Section B2.0 for data. (These data were used for comparison purposes; these data have not been validated and should be used with caution.)

- The solids composite inventory estimate for this tank (Agnew et al. 1996) generated from the Los Alamos National Laboratory (LANL) model, also referred to as the Historical Tank Content Estimate (HTCE). See Appendix A, Section A3.2 for model estimate.

A list of references used in this evaluation is provided at the end of this Appendix (Section D4.0).

\section{D2.0 COMPARISON OF COMPONENT INVENTORY VALUES}

Sampling-based inventories (see Appendix B, Section B3.2), derived from the analytical concentration data from the two auger samples, and HTCE inventories, generated by the LANL model (See Appendix A, Section A3.2), are compared in Tables D2-1 and D2-2. 
Table D2-1 compares nonradioactive components on a metric ton (MT) basis, and Table D2-2 compares the radioactive components on a curie basis.

Table D2-1. Sampling- and HTCE-based Inventory Estimates for Nonradioactive Components in Tank 241-T-109 Waste. (2 sheets)

\begin{tabular}{|c|c|c|c|c|c|}
\hline (2) & 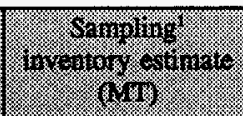 & $\frac{1106}{411}$ & $(2)$ & 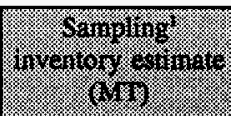 & 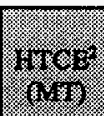 \\
\hline $\mathrm{Al}$ & 0.43 & 1.0 & $\mathrm{Ni}$ & $n / a$ & 0.15 \\
\hline $\mathrm{Ag}$ & 0.006 & NR & $\mathrm{NO}_{2}$ & 0.17 & 2.9 \\
\hline As & $n / a$ & NR & $\mathrm{NO}_{3}$ & 7.1 & 42 \\
\hline $\mathrm{Ba}$ & $n / a$ & NR & $\mathrm{OH}_{\text {total }}$ & NR & 5.4 \\
\hline $\mathrm{Be}$ & $n / a$ & NR & oxalate & $n / a$ & 0 \\
\hline $\mathrm{Bi}$ & 0.058 & 2.1 & $\mathrm{~Pb}$ & 0.10 & 0 \\
\hline $\mathrm{Ca}$ & 0.11 & 1.0 & $P d$ & $n / a$ & NR \\
\hline $\mathrm{Ce}$ & $n / a$ & NR & $\mathrm{P}$ as $\mathrm{PO}_{4}$ & $84-92^{3}$ & 35 \\
\hline $\mathrm{Cd}$ & $n / a$ & NR & $\mathrm{Pt}$ & NR & NR \\
\hline $\mathrm{Cl}$ & 0.099 & 0.64 & Rh & NR & NR \\
\hline $\mathrm{Co}$ & $n / a$ & NR & Ru & NR & NR \\
\hline $\mathrm{Cr}$ & 0.014 & 0.06 & $\mathbf{S b}$ & $n / a$ & NR \\
\hline $\mathrm{Cr}^{+3}$ & NR & NR & $\mathrm{Se}$ & $n / a$ & NR \\
\hline $\mathrm{Cr}^{+6}$ & NR & NR & $\mathrm{Si}$ & 0.30 & 0.15 \\
\hline Cs & NR & NR & $\mathrm{S}$ as $\mathrm{SO}_{4}$ & 0.18 & 2.9 \\
\hline $\mathrm{Cu}$ & $n / a$ & NR & $\mathrm{Sr}$ & $n / a$ & 0 \\
\hline$F$ & 4.5 & 0.61 & $\mathrm{Te}$ & $\mathrm{NR}$ & NR \\
\hline $\mathrm{Fe}$ & 1.9 & 2.7 & TIC as $\mathrm{CO}_{3}$ & NR & 3.3 \\
\hline $\mathrm{FeCN} / \mathrm{CN}$ & NR & 0 & Th & $n / a$ & NR \\
\hline formate & NR & NR & $\mathrm{T1}$ & NR & NR \\
\hline $\mathrm{Hg}$ & NR & 0.0017 & TOC & NR & $\mathrm{NR}$ \\
\hline $\mathbf{K}$ & $n / a$ & 0.12 & $\mathrm{U}_{\text {towal }}$ & $n / a$ & NR \\
\hline $\mathbf{L a}$ & $n / a$ & 0 & $\mathrm{v}$ & $n / a$ & NR \\
\hline $\mathrm{Mg}$ & 0.038 & $\mathrm{NR}$ & $w$ & NR & NR \\
\hline
\end{tabular}


Table D2-1. Sampling- and HTCE-based Inventory Estimates for Nonradioactive Components in Tank 241-T-109 Waste. (2 sheets)

\begin{tabular}{|c|c|c|c|c|c|}
\hline (1) & 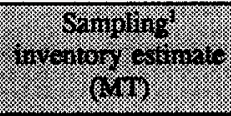 & 40 & - & 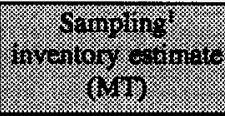 & inger \\
\hline $\mathrm{Mn}$ & 0.35 & 0 & $\mathrm{Zn}$ & 0.094 & NR \\
\hline Mo & $n / a$ & NR & $\overline{\mathrm{Zr}}$ & 0.004 & 0.067 \\
\hline $\mathrm{Na}$ & 62 & 47 & $\mathrm{H}_{2} \mathrm{O}(\mathrm{wt} \%)$ & 47.7 & 57.2 \\
\hline Nd & $\mathrm{n} / \mathrm{a}$ & NR & \multirow{2}{*}{$\begin{array}{l}\text { density } \\
(\mathrm{g} / \mathrm{mL})\end{array}$} & \multirow[t]{2}{*}{ NR } & \multirow[t]{2}{*}{1.55} \\
\hline $\mathrm{NH}_{4}$ & NR & NR & & & \\
\hline
\end{tabular}

Notes:

MT $=$ metric ton
n/a $=$ Not applicable; i.e., concentration reported as less than value.
NR $=$ Not reported.

${ }^{1}$ Conner (1995) - See Appendix B.

${ }^{2}$ Agnew et al. (1996) - See Appendix A.

${ }^{3}$ Range reflects two methods of analysis.

Table D2-2. Sampling and Predicted Inventory Estimates for Radioactive Components in Tank 241-T-109 Waste.

\begin{tabular}{|c|c|c|c|c|c|}
\hline (3) & 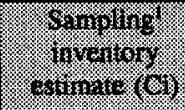 & 1\% & (1) & 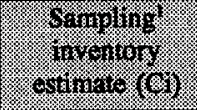 & Inder (9) \\
\hline${ }^{14} \mathrm{C}$ & NR & NR & ${ }^{237} \mathrm{~Np}$ & NR & NR \\
\hline${ }^{90} \mathrm{Sr}$ & NR & 3,760 & ${ }^{239 / 240} \mathrm{Pu}$ & NR & 2.35 \\
\hline${ }^{99} \mathrm{Tc}$ & NR & NR & ${ }^{241} \mathrm{Am}$ & $\mathrm{NR}$ & NR \\
\hline${ }^{129} I$ & NR & NR & Total $\alpha$ & 4.69 & NR \\
\hline${ }^{137} \mathrm{Cs}$ & NR & 4,150 & Total $\beta$ & NR & NR \\
\hline${ }^{154} \mathrm{Eu}$ & NR & NR & & & \\
\hline
\end{tabular}

Notes:

$\mathrm{n} / \mathbf{a}=$ Not applicable; i.e., concentration reported as less than value.

NR $=$ Not reported.

'Conner (1995) - See Appendix B.

${ }^{2}$ Agnew et al. (1996) - See Appendix A. 


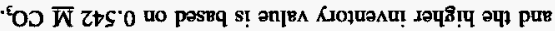

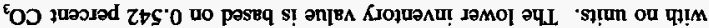

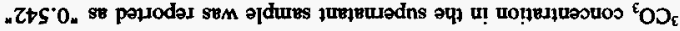

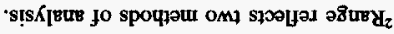

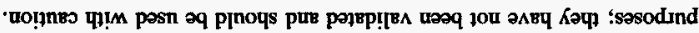

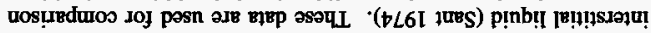

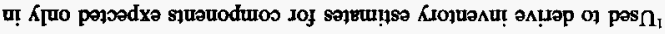

$$
\begin{aligned}
& \text { pejrodar poN = } \mathrm{dN}
\end{aligned}
$$

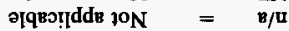

$$
\begin{aligned}
& \text { uol sụpuI = LW }
\end{aligned}
$$

$: \$ 210 \mathrm{~N}$

\begin{tabular}{|c|c|c|c|}
\hline$\angle t$ & $\mathrm{E} / \mathrm{u}$ & 29 & $\mathrm{e}_{\mathbf{N}}$ \\
\hline$\varepsilon^{*} \varepsilon$ & $\varepsilon^{\circ} \varepsilon-Z 6^{\circ} 0$ & dN & ${ }^{\mathrm{O} O J}$ \\
\hline 6.2 & $L I$ & $8 I^{\circ} 0$ & ${ }^{\mathrm{t}} \mathrm{OS}$ \\
\hline $6 \%$ & I.S & $\angle I^{\circ} 0$ & ${ }^{2} \mathrm{ON}$ \\
\hline$z t$ & 9.9 & $I L$ & ${ }^{\varepsilon} \mathrm{ON}$ \\
\hline I9:0 & $\mathrm{e} / \mathrm{u}$ & $s . t$ & H \\
\hline SE & $\mathrm{e} / \mathrm{u}$ & $226-+8$ & ${ }^{p} \mathrm{Od}$ \\
\hline$(191) \%$ & 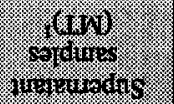 & 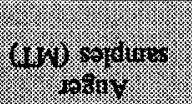 & worgatiog. \\
\hline
\end{tabular}

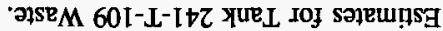

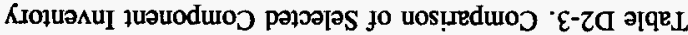

' uọ̣nes uฺ!̣ pəsn aq pInous

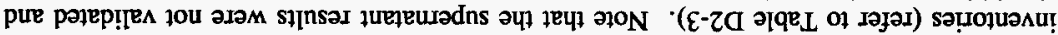

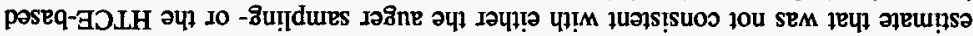

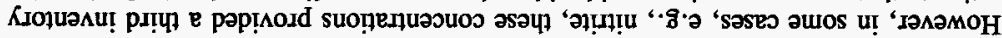

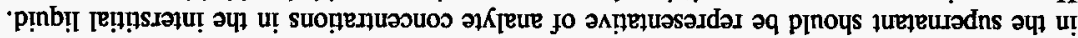

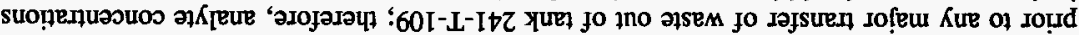

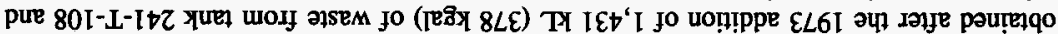

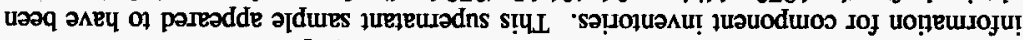

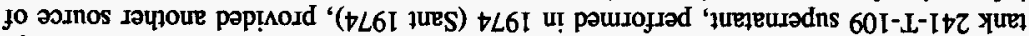

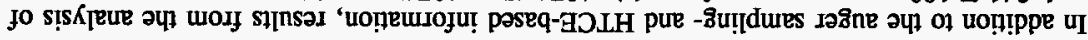


Sampling-based component inventories were calculated by multiplying the mean analyte concentration value by the current tank waste volume and by the density of the waste. A tank volume of $220 \mathrm{~kL}$ (58 kgal) (Hanlon 1996) and a density of $1.55 \mathrm{~g} / \mathrm{mL}$ were used in these calculations. The density of $1.55 \mathrm{~g} / \mathrm{mL}$ reflects the LANL model density (Agnew et al. 1996) because no density measurements were performed on the recent auger samples. This density is consistent with densities of $1.6 \mathrm{~g} / \mathrm{mL}$ for $\mathrm{Na}_{3} \mathrm{PO}_{4} \cdot 12 \mathrm{H}_{2} \mathrm{O}$ and 1.5 for $\mathrm{Na}_{2} \mathrm{HPO}_{4} \cdot 12 \mathrm{H}_{2} \mathrm{O}$; phosphate appears to be a bulk constituent in this waste (refer to Table D2-1).

The following evaluation of tank contents was performed in order to identify potential errors and/or missing information that could influence the sampling- and/or the HTCE-based component inventories.

\section{D3.0 COMPONENT INVENTORY EVALUATION}

Tank 241-T-109, the third tank in a cascade group comprised of tanks 241-T-107, 241-T-108, and 241-T-109, received/transferred (Agnew et al. 1996):

through 1953 Received overflow 1C, UR wastes from tank 241-T-108

1951-1953 Supernatant sent to tank 241-TX-118

1953-1954 Received supernatant from tank 241-TX-117

$1954 \quad$ Evaporator waste received

1969 Supernatant sent to tank 241-TY-103 (515 kL [136 kgal] waste remains)

1973 Received $1,514 \mathrm{~kL}$ (400 kgal) supernatant from tank 241-T-108 (potentially B Plant wash/LL/IX waste)

1974 Supernatant sampled, 1,499 kL (396 kgal) transferred to tank 241-S-110; tank removed from service.

Notes: $\quad 1 \mathrm{C} \quad$ First decontamination cycle $\mathrm{BiPO}_{4}$ waste

UR Uranium recovery waste (tributyl phosphate waste)

LL Low-level

IX Ion-exchange

(Please refer to Appendix A, Section A3.1 for a more detailed summary of the waste transfer history.) 
LANL sets the waste type in this tank as T1-saltcake (T1SltCk) beginning 1955 and does not take into account any solids contributions and/or waste dilution effects from the $1,514 \mathrm{~kL}$ (400 kgal) of supernatant waste transferred from tank $241-\mathrm{T}-108$ in 1973 . This $1,514 \mathrm{~kL}$ would most likely alter the composition of the $515 \mathrm{~kL}(136 \mathrm{kgal})$ of salt waste in the tank at that time. The T1SltCk composition is compared with the auger sampling-based composition on a dry weight percent basis in Table D3-1.

Table D3-1. Comparison of Auger Sampling and HTCE Waste Compositions for Tank 241-T-109 on a Dry Weight Percent Basis.

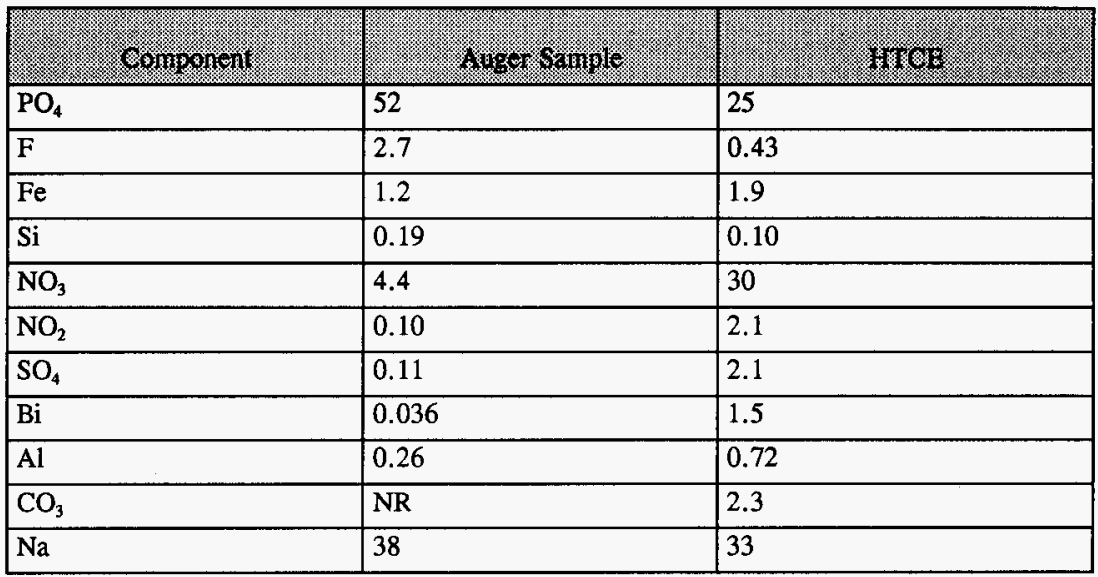

The bulk of LANL's T1SltCk is comprised of $\mathrm{Na}, \mathrm{NO}_{3}$, and $\mathrm{PO}_{4}$, while the bulk of the auger sample is comprised of $\mathrm{Na}$ and $\mathrm{PO}_{4}$. Phosphate concentration values appeared consistent for all analyzed auger-sample segments, and the high concentration values suggested that all/nearly all of the $\mathrm{PO}_{4}$ precipitated from the aqueous salt stream sent to the tank. LANL assumed that only 58 percent of the $\mathrm{PO}_{4}$ precipitated.

The following observations are made for several of the individual components listed in Tables D2-3 and D3-1:

Phosphate: Phosphate concentration values appeared consistent for all analyzed auger-sample segments. The high inventory value derived from these concentrations also suggests that all/nearly all of the $\mathrm{PO}_{4}$ precipitated from the aqueous salt waste. The LANL assumption that only 58 percent of the $\mathrm{PO}_{4}$ precipitated is reflected in the significantly lower HTCE inventory value. 
Fluoride: The mean concentration value that was used to generate the auger sampling-based inventory was based on two very different concentration values-- $800 \mu \mathrm{g} \mathrm{F} / \mathrm{g}$ waste in one sample and $25,000 \mu \mathrm{g} \mathrm{F} / \mathrm{g}$ waste in the other. These difference in concentration could be due to two distinct waste types in the tank and/or to inhomogeneous dilution effects. These sampling-based values suggest that some of the fluoride precipitated from solution, while the HTCE concentration and resulting inventory values are based on the assumption that fluoride remains dissolved in interstitial liquid.

Nitrate: The mean concentration value that was used to generate the auger sampling-based inventory was derived from two very different concentration values--38,000 $\mu \mathrm{g} \mathrm{NO}_{3} / \mathrm{g}$ waste in one sample (corresponding to the $800 \mu \mathrm{g} \mathrm{F} / \mathrm{g}$ waste sample) and $3500 \mu \mathrm{g} \mathrm{NO}_{3} / \mathrm{g}$ waste in the other (corresponding to $23,000 \mu \mathrm{g} \mathrm{F} / \mathrm{g}$ waste sample). These different values could be due to two distinct waste types in the tank and/or to inhomogeneous dilution effects. The inventory value in Table D2-3, derived from the supernatant sample, compares favorably with the inventory based on the auger sample. This observation tends to support the assumption that analyte concentrations in the supernatant might be representative of present analyte concentrations in the interstitial liquid. The concentration in T1SItCk is considerably higher than the sampling-based concentration values; the HTCE concentration value does not account for any potential dilution effects from the addition of $1,462 \mathrm{~kL}$ (386 kgal) of aqueous waste in 1973.

Nitrite: The auger and supernatant-based inventories in Table D2-3 for $\mathrm{NO}_{2}$ are very different (0.17 MT, auger versus 5.1 MT, supernatant). In contrast to $\mathrm{NO}_{3}$, this observation does not support the assumption that the analyte concentration in the supernatant might be representative of present analyte concentrations in the interstitial liquid. While the HTCE inventory falls within the sampling-based inventory range, the HTCE value could be smaller due to potential dilution effects.

Sulfate: The auger and supernatant-based inventories in Table D2-3 for $\mathrm{SO}_{4}$ vary by an order of magnitude. In contrast to $\mathrm{NO}_{3}$, this observation does not support the assumption that the analyte concentration in the supernatant might be representative of present analyte concentrations in the interstitial liquid. The HTCE inventory falls outside the sampling-based inventory range; however, the HTCE value may be smaller due to potential dilution effects.

Bismuth: The HTCE inventory is larger than the auger sampling-based inventory. Tank 241-T-109 was the third tank in the cascade series, and as a result $\mathrm{Bi}$, a heavy element, may have precipitated in the first two tanks.

Carbonate: Auger samples were not analyzed for $\mathrm{CO}_{3}$. The range in Table D3-1 results from the concentration in the supernatant sample being reported as "0.542," with no units provided. Because carbonate analyses were reported in the past both in terms of percent mass or molarity, two inventory values were generated: the lower inventory value is based on 0.542 percent $\mathrm{CO}_{3}$, and the upper inventory value is based on $0.542 \mathrm{M} \mathrm{CO}$. The HTCE inventory falls within this range. 
With two modifying assumptions, the HTCE component inventories begin to compare favorably with the sampling-based inventories. First, assume all the $\mathrm{PO}_{4}$ in the LANL defined waste stream precipitates, and second, assume the components dissolved in the interstitial liquid are diluted by a factor of 7 . The resulting HTCE composition is compared to the auger sample composition on a dry weight percent basis in Table D3-2.

Table D3-2. Comparison of Auger Sampling and Modified HTCE Component Inventories for Tank 241-T-109 Waste on a Dry Weight Percent Basis.

\begin{tabular}{|c|c|c|}
\hline 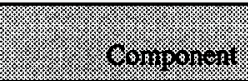 & 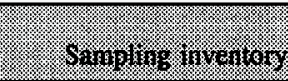 & 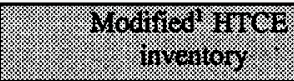 \\
\hline $\mathrm{PO}_{4}$ & 52 & 51 \\
\hline $\bar{F}$ & 2.7 & 0.51 \\
\hline $\mathrm{Fe}$ & 1.2 & 2.2 \\
\hline$\overline{\mathrm{Si}}$ & 0.19 & 0.12 \\
\hline $\mathrm{NO}_{3}$ & 4.4 & 4.8 \\
\hline $\mathrm{NO}_{2}$ & 0.10 & 0.34 \\
\hline $\mathrm{SO}_{4}$ & 0.11 & 0.34 \\
\hline $\mathrm{Bi}$ & 0.036 & 1.6 \\
\hline$\overline{\mathrm{Al}}$ & 0.26 & 0.12 \\
\hline $\mathrm{CO}_{3}$ & NR & 2.6 \\
\hline $\mathrm{Na}$ & 38 & 38 \\
\hline
\end{tabular}

Note:

'All $\mathrm{PO}_{4}$ in the LANL defined waste stream is assumed to precipitate, and the remaining salts dissolved in the interstitial liquid are assumed to have been diluted by a factor of 7 . 


\section{D4.0 DEFINE THE BEST-BASIS AND ESTABLISH COMPONENT INVENTORIES}

The results from this evaluation support using the sampling data as the basis for the best estimate inventory for tank 241-T-109 for the following reasons:

1. The inventory estimate generated by the LANL model is based on a single defined salt waste stream (T1SltCk) and does not take into account any solids contributions and/or waste dilution effects from the $1,431 \mathrm{~kL}$ ( $378 \mathrm{kgal}$ ) of waste transferred from tank 241-T-108 to tank 241-T-109 in 1973. This $1,431 \mathrm{~kL}$ is not considered to be T1SitCk and most likely altered the composition of the $515 \mathrm{~kL}(136 \mathrm{kgal})$ of salt waste in the tank at that time.

2. Phosphate concentration values, which appear consistent for all analyzed segments, suggest that phosphates formed the bulk of the precipitated solids. The predicted concentration value for this major component is less than half the lower 95 percent confidence value. The LANL assumption that only 40 percent of the phosphate in the $\mathrm{Tl}$ waste stream precipitates appears to be conservative.

Best-basis inventory estimates for tank 241-T-109 are presented in Tables D4-1 and D4-2. While samples were analyzed for numerous analytes (refer to Table D2-1), only those detected in the waste are included in these tables. Table D4-1 provides an inventory estimate in terms of percent nonradioactive (expected) chemical species. Note that this waste is predominantly sodium phosphate and should not be mixed with waste types that could result in phosphate gels.

Best-basis component inventory estimates and the mean analytical concentrations that were used to calculate these component inventories are provided in Table D4-2. This table also includes 95 percent confidence intervals around the mean concentration value (refer to Appendix B for information regarding the statistical analysis of analytical data for tank 241-T-109). Note that inventory ranges are presented in Table D4-2 for $\mathrm{NO}_{2}, \mathrm{TIC}$ as $\mathrm{CO}_{3}$, and $\mathrm{SO}_{4}$. These ranges result from the uncertainties associated with these components. 
Table D4-1. Best-Basis Inventory Estimate for Tank 241-T-109 (Percent Nonradioactive Chemical Species).

\begin{tabular}{|c|c|c|}
\hline \multicolumn{2}{|c|}{83198831964} & 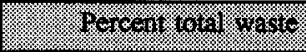 \\
\hline \multicolumn{2}{|l|}{ Water } & 48 \\
\hline \multicolumn{2}{|l|}{ Sodium phosphate $^{1}$} & $40-44$ \\
\hline \multicolumn{2}{|l|}{ Sodium fluoride } & 2.9 \\
\hline \multicolumn{2}{|l|}{ Sodium nitrate } & 2.9 \\
\hline \multicolumn{2}{|l|}{ Sodium nitrite $^{2}$} & $0.074-2.3$ \\
\hline \multicolumn{2}{|l|}{ Sodium sulfate ${ }^{2}$} & $0.076-0.75$ \\
\hline \multicolumn{2}{|l|}{ Sodium carbonate $^{3}$} & $0.48-1.8$ \\
\hline \multicolumn{2}{|l|}{ Minor compounds: } & 1.6 \\
\hline Iron hydroxide & 0.87 & \\
\hline Aluminum hydroxide & 0.36 & \\
\hline Silicon dioxide & 0.19 & \\
\hline Manganese hydroxide & 0.17 & \\
\hline Calcium carbonate & 0.081 & \\
\hline Sodium chloride & 0.047 & \\
\hline Zinc hydroxide & 0.029 & \\
\hline Bismuth oxide & 0.019 & \\
\hline
\end{tabular}

Notes:

${ }^{1}$ Range accounts for range in sodium sulfate, sodium nitrite, and sodium carbonate inventories; refer to (2) and (3) below.

${ }^{2}$ Low value based on auger sample analysis; high value based on 1974 supernatant analysis.

${ }^{3}$ Low value based on 0.542 percent $\mathrm{CO}_{3}$ in supernatant sample, and high value based on $0.542 \underline{\mathrm{M}} \mathrm{CO}_{3}$. 


\begin{tabular}{|c|c|c|c|c|c|}
\hline 9 & B/U & $\mathrm{e} / \mathrm{u}$ & $\mathrm{B} / \mathrm{U}$ & $9.8 \mathrm{I}$ & $\begin{array}{r}\text { (p!̣V/dDI) } \\
\text { ฮิ }\end{array}$ \\
\hline$O E^{\circ} 0$ & $\mathbf{e} / \mathrm{u}$ & $\mathrm{B} / \mathrm{U}$ & $\mathrm{B} / \mathrm{U}$ & 688 & $\begin{array}{r}\text { (uoḷn } / \text { /dOI) } \\
\text { IS }\end{array}$ \\
\hline $\begin{array}{r}{ }_{t} E 8 \\
-26 \\
\end{array}$ & $\mathbf{N}$ & 000IEE & $00086 \mathrm{I}$ & $\begin{array}{r}20009 t z \\
-00069 z \\
\end{array}$ & 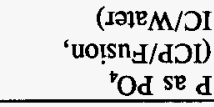 \\
\hline 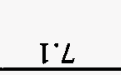 & $\boldsymbol{X}$ & 000 It 2 & 0 & 00802 & $\begin{array}{r}\text { (IәIEM/DI) } \\
{ }^{\varepsilon} \mathrm{ON} \\
\end{array}$ \\
\hline $\begin{array}{r}I^{\prime} S \\
-\angle I \cdot 0 \\
\end{array}$ & $\mathbf{E} / \mathbf{U}$ & $\mathrm{e} / \mathrm{u}$ & $\mathrm{e} / \mathrm{u}$ & $\begin{array}{l}000 S I \\
-26 t\end{array}$ & $\begin{array}{r}(\text { मәIе } M / D I) \\
{ }_{2}^{2} \mathrm{ON} \\
\end{array}$ \\
\hline$z 29$ & $\boldsymbol{X}$ & $0000 \angle \mathcal{E}$ & 0 & $00018 \mathrm{I}$ & $\begin{array}{r}\left.\text { uloisn }_{\mathrm{H} / \mathrm{d} D \mathrm{I}}\right) \\
\mathrm{e}_{\mathrm{N}}\end{array}$ \\
\hline SE0 & $\boldsymbol{X}$ & $090 L$ & 0 & OEOI & $\begin{array}{r}(\text { uoisn } \mathrm{H} / \mathrm{dOI}) \\
\text { uW }\end{array}$ \\
\hline $8 \mathcal{E}$ & $\mathrm{e} / \mathrm{u}$ & $\mathrm{e} / \mathrm{U}$ & $\mathbf{e} / \mathbf{u}$ & II I & $\begin{array}{r}\text { (p!๐ /dDI) } \\
\text { ชี }\end{array}$ \\
\hline $00 \mathrm{I}$ & $\mathrm{e} / \mathrm{u}$ & $\mathrm{e} / \mathrm{U}$ & $\mathbf{e} / \mathrm{U}$ & $\varepsilon 0 E$ & $\begin{array}{r}(\mathrm{p}) \mathrm{V} / \mathrm{d} D \mathrm{I}) \\
\mathrm{qd} \\
\end{array}$ \\
\hline $6^{\circ} \mathrm{I}$ & $\boldsymbol{X}$ & 00892 & 0 & $06 t S$ & $\begin{array}{r}(\text { uoisn } / \text { /dOI) } \\
\partial_{H} \\
\end{array}$ \\
\hline$s^{*} t$ & $\boldsymbol{X}$ & $00089 I$ & 0 & OOOEI & $\begin{array}{r}\text { (IכIEM/OI) } \\
\text { H }\end{array}$ \\
\hline$\$ 10^{\circ} 0$ & $\mathrm{e} / \mathrm{u}$ & $\mathrm{E} / \mathrm{U}$ & $\mathbf{e} / \mathbf{u}$ & $0 t$ & 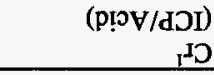 \\
\hline $\mathrm{ZI} 0$ & $\mathrm{E} / \mathrm{u}$ & $\mathrm{e} / \mathrm{U}$ & $\mathrm{e} / \mathrm{U}$ & $I \downarrow \mathcal{E}$ & $\begin{array}{r}\text { (IอIEM/DI) } \\
\text { ID } \\
\end{array}$ \\
\hline II 0 & $\mathbf{e} / \mathbf{u}$ & $\mathrm{e} / \mathrm{U}$ & $\mathrm{e} / \mathrm{u}$ & $\nabla Z \mathcal{E}$ & $\begin{array}{r}\text { (pIov/doI) } \\
\text { e? }\end{array}$ \\
\hline $\pm L$ & $\mathrm{e} / \mathrm{U}$ & $\mathrm{E} / \mathrm{U}$ & $\mathrm{e} / \mathrm{U}$ & $L I Z$ & $\begin{array}{r}(\mathrm{p!O} / \mathrm{dOI}) \\
\mathrm{g} \\
\end{array}$ \\
\hline $850^{\circ} 0$ & $\mathrm{e} / \mathrm{u}$ & $\mathrm{E} / \mathrm{U}$ & $\mathrm{e} / \mathrm{u}$ & $0<\mathrm{I}$ & 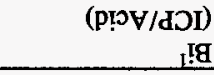 \\
\hline$\varepsilon t^{\circ} 0$ & $\boldsymbol{X}$ & OOEE & 0 & OSZI & $\begin{array}{r}\left.\text { uoḷsn }_{H} / \mathrm{dDI}\right) \\
\text { IV }\end{array}$ \\
\hline 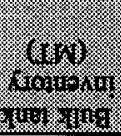 & 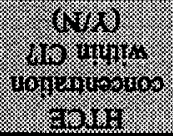 & 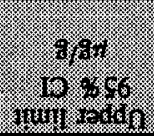 & 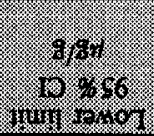 & 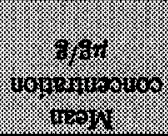 & 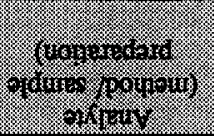 \\
\hline
\end{tabular}

(s)æaบs Z)

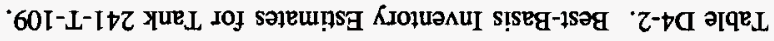




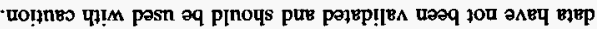

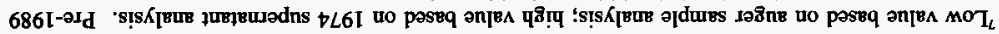

$\mathrm{O}^{\mathrm{z}} \mathrm{HZI} \cdot{ }^{\mathrm{T}} \mathrm{OdH}^{\mathrm{z} \mathrm{B}} \mathrm{N}$

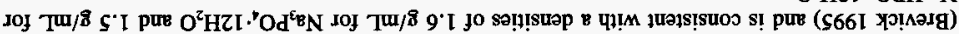

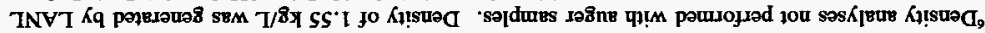

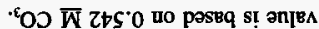

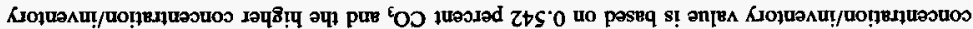
Iәмо

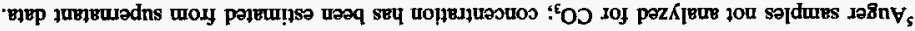

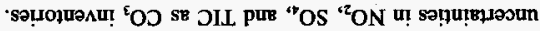

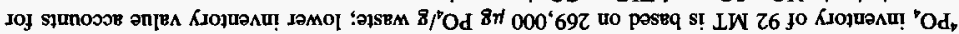

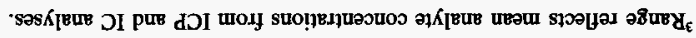

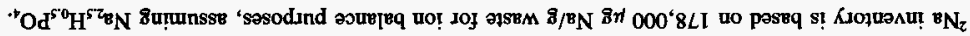

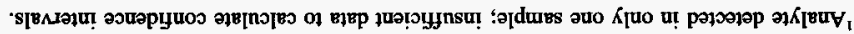

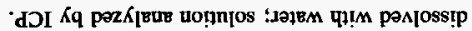

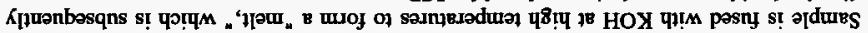

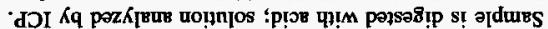

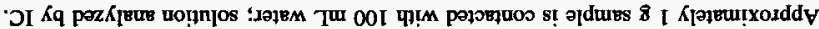
not oujeu

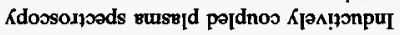

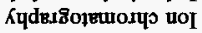

\begin{tabular}{|c|c|c|c|c|c|}
\hline $99^{\circ} \mathrm{I}$ & $\mathrm{e} / \mathrm{u}$ & e/u & $\mathbf{E} / \mathbf{U}$ & $9 S^{\prime} I$ & ${ }_{9}(\mathrm{TU} / 8)$ אitsuəd \\
\hline$\% 1 M 8 t$ & $\boldsymbol{X}$ & $\varepsilon: L S$ & {$[.8 \mathcal{E}$} & $L L t$ & $(\% 1 M) \mathrm{O}^{2} \mathrm{H}$ \\
\hline $10 \angle{ }^{\prime} t$ & X & $I^{\circ} 0$ & 0 & $\angle E I 0^{\circ} 0$ & $\left(8 / ! \rho^{n}\right)$ o [EוLI \\
\hline$t$ & $\mathrm{e} / \mathrm{u}$ & $\mathrm{e} / \mathrm{u}$ & $\mathrm{e} / \mathrm{u}$ & $\tau \cdot Z I$ & $\begin{array}{r}\text { (p!oV/dOI) } \\
\text { IZ }\end{array}$ \\
\hline $560^{\circ} 0$ & $\begin{array}{c}\text { paproday } \\
10 \mathrm{~N}\end{array}$ & SOS & $\varepsilon L t$ & $9 L Z$ & $\begin{array}{r}\left.\text { unọsn }_{\mathrm{d}} / \mathrm{dOI}\right) \\
\mathrm{uZ} \\
\end{array}$ \\
\hline $\begin{array}{r}9^{\circ} \varepsilon \\
-26^{\circ} 0 \\
\end{array}$ & $\mathrm{e} / \mathrm{u}$ & $\mathbf{e} / \mathbf{u}$ & $\mathbf{e} / \mathbf{u}$ & $\begin{array}{r}00+0 \mathrm{I} \\
-0 \mathrm{ILZ} \\
\end{array}$ & $\mathrm{st}_{1}^{E} \mathrm{OD}$ se DIL \\
\hline $\begin{aligned} & L^{\circ} I \\
&- 8 I^{\circ} 0 \\
&\end{aligned}$ & $\mathrm{E} / \mathrm{U}$ & $\mathrm{E} / \mathrm{U}$ & e/u & $\begin{array}{l}0 S 0 S \\
-9 I S\end{array}$ & $\begin{array}{l}\text { (p!ov/dDI) } \\
{ }_{4}^{\dagger} \mathrm{OS} \text { SE S }\end{array}$ \\
\hline 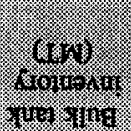 & 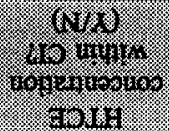 & 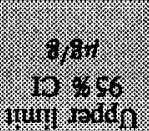 & 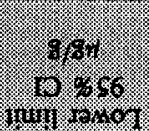 & 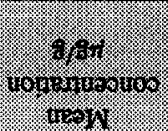 & (1) \\
\hline
\end{tabular}

(s1204S Z)

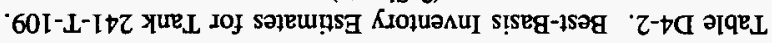




\section{D5.0 APPENDIX D REFERENCES}

Agnew, S. F., J. Boyer, R. A. Corbin, T. B. Duran, J. R. Fitzpatrick, K. A. Jurgensen, T. P. Ortiz, and B. L. Young, 1996, Hanford Chemical and Radionuclide Inventories: HDW Model Rev. 3, LA-UR-96-858, Los Alamos National Laboratory, Los Alamos, New Mexico.

Brevick, C. H., L. A. Gaddis, and E. D. Johnson, 1995, Historical Tank Content Estimate for the Northwest Quadrant of the Hanford 200 East Areas, WHC-SD-WM-ER-351, Rev. 0, Westinghouse Hanford Company, Richland, Washington.

Conner, J. M., 1995, Final Report for Tank 241-T-109, Auger Samples 95-AUG-040 and 95-AUG-041, WHC-SD-WM-DP-144, Rev. 1-A, Westinghouse Hanford Company, Richland, Washington.

Hanlon, B. M., 1996, Waste Tank Summary Report for Month Ending April 30, 1996, WHC-EP-0182-97, Westinghouse Hanford Company, Richland, Washington.

Kupfer, M. J., M. D. LeClair, W. W. Schulz, and L. W. Shelton, 1995, Work Plan for Defining a Standard Inventory Estimate for Wastes Stored in Hanford Site Underground Tanks, WHC-SD-WM-WP-311, Rev. 0, Westinghouse Hanford Company, Richland, Washington.

Sant, W. H., 1974, Analysis of Tank Farm Samples, Sample: T-2289, Tank 109-T, (internal memorandum to R. L. Walser, March 13), Atlantic Richfield Hanford Company, Richland, Washington. 
WHC-SD-WM-ER-559 Rev. 0

This page intentionally left blank. 
WHC-SD-WM-ER-559 Rev. 0

APPENDIX E

BIBLIOGRAPHY FOR TANK 241-T-109

E-1 
WHC-SD-WM-ER-559 Rev. 0

This page intentionally left blank. 


\section{APPENDIX E}

\section{BIBLIOGRAPHY FOR TANK 241-T-109}

Appendix E provides a bibliography of information that supports the characterization of tank 241-T-109. This bibliography represents an in-depth literature search of all known information sources that provide sampling, analysis, surveillance, and modeling information, as well as processing occurrences associated with tank 241-T-109 and its respective waste types.

The references in this bibliography are separated into three broad categories containing references broken down into subgroups. These categories and their subgroups are listed below.

\section{NON-ANALYTICAL DATA}

Ia. Models/Waste Type Inventories/Campaign Information

Ib. Fill History/Waste Transfer Records

Ic. Surveillance/Tank Configuration

Id. Sample Planning/Tank Prioritization

Ie. Data Quality Objectives/Customers of Characterization Data

\section{ANALYTICAL DATA - SAMPLING OF TANK WASTE AND WASTE TYPES}

IIa. Sampling of tank 241-T-109

IIb. Sampling of 242-T Evaporator Streams

IIc. Sampling of TBP-Salt Mixtures

\section{COMBINED ANALYTICAL/NON-ANALYTICAL DATA}

IIIa. Inventories using both Campaign and Analytical Information

IIIb. Compendium of Existing Physical and Chemical Documented Data Sources

This bibliography is broken down into the appropriate sections of material to use, with an annotation at the end of each reference describing the information source. Where possible, a reference is provided for information sources. A majority of the information listed below may be found in the Westinghouse Hanford Company Tank Characterization Resource Center. 


\section{NON-ANALYTICAL DATA}

Ia. Models/Waste Type Inventories/Campaign Information

Anderson, J. D., 1990, A History of the 200 Area Tank Farms, WHC-MR-0132, Westinghouse Hanford Company, Richland, Washington.

- Document contains single-shell tank fill history and primary campaign/waste type information up to 1981 .

Jungfleisch, F. M. and B. C. Simpson, 1993, Preliminary Estimation of the Waste Inventories in Hanford Tanks Through 1980, WHC-SD-WM-TI-057 Rev. 0-A, Westinghouse Hanford Company, Richland, Washington.

- A model based on process knowledge and radioactive decay estimations using ORIGEN for different compositions of process waste streams assembled for total, solution, and solids compositions per tank. Assumptions about waste/waste types and solubility parameters/constraints are also given.

Schneider, K. J., 1951, Flow Sheet and Flow Diagrams of Precipitation Separations Process, HW-23043, General Electric Company, Richland, Washington.

- Document contains compositions of first concentration cycle waste before transfer to $200 \mathrm{E}$ waste tanks.

Ib. Fill History/Waste Transfer Records

Agnew, S. F., 1995, Tank Layer Model (TLM), Rev 1 for Northeast, Southwest, and Northwest Quadrants, LA-UR-94-4269, Rev. 1, Los Alamos National Laboratory, Los Alamos, New Mexico.

- Document predicts volumes of waste type layers in single-shell tanks.

Agnew, S. F., R. A. Corbin, T. B. Duran, K. A. Jurgensen, T. P. Ortiz, and B. L. Young, 1994, Waste Status and Transaction Record Summary for the Northwest Quadrant of the Hanford 200 East Area, WHC-SD-WM-TI-669, Rev. 1, Los Alamos National Laboratory, Los Alamos, New Mexico.

- Document contains spreadsheets depicting all available data on tank additions/transfers. 
Anderson, J. D., 1990, A History of the 200 Area Tank Farms, WHC-MR-0132, Westinghouse Hanford Company, Richland, Washington.

- Document contains single-shell tank fill history and primary campaign/waste type information up to 1981 .

Ic. Surveillance/Tank Configuration

Alstad, A. T., 1993, Riser Configuration Document for Single-Shell Waste Tanks, WHC-SD-RE-TI-053, Rev. 9, Westinghouse Hanford Company, Richland, Washington.

- Document shows tank riser locations in relation to tank aerial view as well as a description of riser and its contents.

Lipnicki, J., 1995, Waste Tank Risers Available for Sampling, WHC-SD-WM-TI-710, Rev. 1, Westinghouse Hanford Company, Richland, Washington.

- Document gives an assessment of riser locations for each tank, however not all tanks are included/completed. Also included is an estimate of what risers are available for sampling.

Id. Sample Planning/Tank Prioritization

Brown, T. M., S. J. Eberlein, and T. J. Kunthara, 1995, Tank Waste Characterization Basis, WHC-SD-WM-TA-164, Rev. 1, Westinghouse Hanford Company, Richland, Washington.

- Document that summarizes the technical basis for characterizing the waste in the tanks and assigns a priority number to each tank.

Conner, J. M., 1995, Tank 241-T-109 Tank Characterization Plan, WHC-SD-WM-TP-368, Rev. 0, Westinghouse Hanford Company, Richland, Washington.

- Document discusses any and all relevant DQOs and how they will be met for tank 241-T-109.

Conner, J. M., 1995, Tank 241-T-109 Auger Sampling and Analysis Plan, WHC-SD-WM-TSAP-014, Rev. 0-A, Westinghouse Hanford Company, Richland, Washington.

- Document contains detailed sampling and analysis procedure information for tank 241-T-109 based on applicable DQOs. 
Conner, J. M., 1995, Need Identified to Resample Tank 241-T-109, (internal memo \#75310-95-098 to T. J. Kelley, October 24), Westinghouse Hanford Company, Richland, Washington.

- Memo summarizes 1995 decision to take additional samples from tank 241-T-109 to meet Safety Screening DQO needs.

Grimes, G. W., 1977, Hanford Long-Term Defense High-Level Waste Management Program Waste Sampling and Characterization Plan, RHO-CD-137, Rockwell Hanford Operations, Richland, Washington.

- Early characterization planning document.

Homi, C. S., 1995, FY 1996 Tank Waste Analysis Plan, WHC-SD-WM-PLN-101, Rev. 0, Westinghouse Hanford Company, Richland, Washington.

- Document contains Tri-Party Agreement (see Ecology et al. 1994 listing in Section 5.0) requirement-driven TWRS Characterization Program information and a list of tanks addressed in fiscal year 1996.

Winters, W. I., L. Jensen, L. M. Sasaki, R. L. Weiss, J. F. Keller, A. J. Schmidt, and M. G. Woodruff, 1989, Waste Characterization Plan for the Hanford Site Single-Shell Tanks, WHC-EP-0210, Westinghouse Hanford Company, Richland, Washington.

- Early version of characterization planning document.

Ie. Data Quality Objectives (DQO) and Customers of Characterization Data

Dukelow, G. T., J. W. Hunt, H. Babad, and J. E. Meacham, 1995, Tank Safety Screening Data Quality Objective, WHC-SD-WM-SP-004, Rev. 2, Westinghouse Hanford Company, Richland, Washington.

- DQO used to determine if tanks are under safe operating conditions.

Kupfer, M. J., W. W. Schultz, G. L. Borsheim, S. J. Eberlein, B. C. Simpson, and J. T. Slankas, 1994, Strategy for Sampling Hanford Site Tank Wastes for Development of Disposal Technology, WHC-SD-WM-TA-154, Westinghouse Hanford Company, Richland, Washington.

- Document provides basis for selection of tanks for disposal needs. 
Simpson, B. C., and D. J. McCain, 1995, Historical Model Evaluation Data Requirements, WHC-SD-WM-DQO-018, Rev. 0-A, Westinghouse, Hanford Company, Richland, Washington.

- Document provides data needs for evaluating the LANL model for estimating tank waste compositions.

Slankas, T. J., M. J. Kupfer, and W. W. Schulz, 1995, Data Needs and Attendant Data Quality Objectives for Tank Waste Pretreatment and Disposal, WHC-SD-WM-DQO-022, Rev. 0, Westinghouse Hanford Company, Richland, Washington.

- Documents the needs of the pretreatment function within TWRS.

\section{ANALYTICAL DATA - SAMPLING OF TANK WASTE AND WASTE TYPES}

IIa. Sampling of tank 241-T-109

Conner, J. M., 1995, Final Report for Tank 241-T-109, Auger Samples 95-AUG-040 and 95-AUG-041, WHC-SD-WM-DP-144, Rev. 1-A, Westinghouse Hanford Company, Richland, Washington.

- Document contains sample analyses from 1995 tank 241-T-109 auger sampling event.

Conner, J. M., 1995, Immediate Notification: Violation of Limits for Moisture Content for Samples from Tank 241-T-109, (internal memo \#75310-95-078 to R. J. Cash, September 21), Westinghouse Hanford Company, Richland, Washington.

- Memo provides sample analysis results that fall outside of acceptable range (Notification limit: < 17 percent moisture) for tank 241-T-109.

Cromar, R. D., 1995, 95\% Confidence Intervals for Tank T-109, (internal memo \#75764-PCS95-083 to J. M. Conner, September 27), Westinghouse Hanford Company, Richland, Washington.

- Memo provides one-sided confidence intervals on 1995 auger data to support the safety screening DQO. 
Sant, W. H., 1974 Analysis of Tank Farm Samples, Sample: T-2289, Tank 109-T, (letter to R. L. Walser, March 13), Atlantic Richfield Hanford Company, Richland, Washington.

- Internal letter provides analyses of supernatant sample from February 9, 1974 sampling.

IIb. Sampling of 242-Evaporator Waste Streams

- All the information in this section is documented in Process Aids 1970 1993. Process Aids is a consecutive compilation of laboratory memos, letters, etc. indexed by year then by subject and/or tank. The following analyses may provide insight as to the composition of T1SltCk waste type expected to be in tank 241-T-109.

Buckingham, J. S., 1972, Interim Report III: Nitric Acid Neutralization and Concentration of Caustic Waste Solutions - 242-T Evaporator Feed, ARH-2529, Atlantic Richfield Hanford Company, Richland, Washington.

Buckingham, J. S., 1972, Nitric Acid Neutralization and Concentration of 242-T Evaporator Recycle Feed, (internal letter, Process Aids \#00256, to W. P. Metz, May 12), Atlantic Richfield Hanford Company, Richland Washington.

Buckingham, J. S. and D. A. Dodd, 1972, Nitric Acid Neutralization and Concentration of Synthetic Recycle Waste Solution, (internal letter, Process Aids $\# 00263$, to D. J. Larkin, July 17), Atlantic Richfield Hanford Company, Richland, Washington.

Puryear, D. A., 1970, Solubility of 242-T Evaporator Process Feed and Concentrate, (internal letter, Process Aids $\# 00088$, to M. C. Fraser, December 9), Atlantic Richfield Hanford Company, Richland, Washington.

Puryear, D. A. and J. S. Buckingham, 1971, Status Report on Waste Solidification Studies and Separations Chemistry Laboratory, (internal letter, Process Aids \#00362, to M. H. Campbell, July 23), Atlantic Richfield Hanford Company, Richland, Washington.

IIc. Sampling of TBP-Salt Mixtures

Barney, G. S, 1970, Thermoanalysis of TBP-Salt Mixtures, (internal letter, Process Aids \#00209, to D. S. Thurman, December 10), Atlantic Richfield Hanford Company, Richland, Washington.

- This letter is documented in Process Aids 1970 - 1993. 


\section{COMBINED ANALYTICAL/NON-ANALYTICAL DATA}

IIIa. Inventories from Campaign and Analytical Information

Agnew, S. F., J. Boyer, R. A. Corbin, T. B. Duran, J. R. Fitzpatrick, K. A. Jurgensen, T. P. Ortiz, and B. L. Young, 1995, Hanford Tank Chemical and Radionuclide Inventories: HDW Rev. 3, LA-UR-96-858, Rev. 0, Los Alamos National Laboratory, Los Alamos, New Mexico.

- Document contains waste type summaries as well as primary chemical compound/analyte and radionuclide estimates for sludge, supernatant, and solids.

Allen, G. K., 1976, Estimated Inventory of Chemicals Added to Underground Waste Tanks, 1944 - 1975, ARH-CD-601B, Atlantic Richfield Hanford Company, Richland, Washington.

- Document contains major components for waste types, and some assumptions. Purchase record are used to estimate chemical inventories.

Allen, G. K., 1975, Hanford Liquid Waste Inventory As Of September 30, 1974, ARH-CD-229, Atlantic Richfield Hanford Company, Richland, Washington.

- Document contains major components for waste types, and some assumptions

Brevick, C. H., L. A. Gaddis, and E. D. Johnson, 1995, Historical Tank Content Estimate for the Northwest Quadrant of the Hanford 200 Areas, WHC-SD-MW-ER-351, Rev. 0, Westinghouse Hanford Company, Richland, Washington.

- Document contains summary information from the supporting document as well as in-tank photo collages and the solid composite inventory estimates Rev. 0 and Rev. 0A.

Brevick, C. H., L. A. Gaddis, and W. W. Pickett, 1995, Supporting Document for the Historical Tank Content Estimate for T Tank Farm, WHC-SD-WM-ER-320, Rev. 0, Westinghouse Hanford Company, Richland, Washington.

- Document contains summary tank farm and tank write-ups on historical data and solid inventory estimates as well as appendices for the data. The appendices contain the following information: Appendix C - Level History AutoCAD sketch; Appendix D - Temperature Graphs; Appendix E - 
Surface Level Graph; Appendix F, pg F-1 - Cascade/ Drywell Chart; Appendix G - Riser Configuration Drawing and Table; Appendix I In-Tank Photos; and Appendix K - Tank Layer Model Bar Chart and Spreadsheet.

IIIb. Compendium of data from other sources physical and chemical

Agnew, S. F., and J. G. Watkin, 1994, Estimation of Limiting Solubilities for Ionic Species in Hanford Waste Tank Supernates, LAUR-94-3590, Los Alamos National Laboratory, Los Alamos, New Mexico.

- Document gives solubility ranges used for key chemical and radionuclide components based on supernatant sample analyses.

Brevick, C. H., L. A. Gaddis, and E. D. Johnson, 1995, Tank Waste Source Term Inventory Validation, Vol I \& II., WHC-SD-WM-ER-400, Rev. 0, Westinghouse Hanford Company, Richland, Washington.

- Document contains a quick reference to sampling information in spreadsheet or graphical form for 23 chemicals and 11 radionuclides for all the tanks.

Hanlon, B. M., 1996, Waste Tank Summary Report for Month Ending April 30, 1996, WHC-EP-0182-97, Westinghouse Hanford Company, Richland, Washington.

- These documents contain a monthly summary of: fill volumes, Watch List tanks, occurrences, integrity information, equipment readings, equipment status, tank location, and other miscellaneous tank information.

Husa, E. I., 1993, Hanford Site Waste Storage Tank Information Notebook, WHC-EP-0625, Westinghouse Hanford Company, Richland, Washington.

- Document contains in-tank photos as well as summaries on the tank description, leak detection system, and tank status.

Husa, E. I., 1995, Hanford Waste Tank Preliminary Dryness Evaluation, WHC-SD-WM-TI-703, Rev. 0, Westinghouse Hanford Company, Richland, Washington.

- Document gives assessment of relative dryness between tanks. 


\begin{tabular}{|c|c|c|c|c|c|}
\hline \multicolumn{6}{|c|}{ DISTRIBUTION SHEET } \\
\hline To & \multirow{2}{*}{\multicolumn{3}{|c|}{ From }} & \multicolumn{2}{|l|}{ Page 1 of 4} \\
\hline Distribution & & & & Date & $5 / 96$ \\
\hline \multicolumn{4}{|l|}{ Project Title/Work Order } & \multicolumn{2}{|c|}{ EDT No. EDT-617544 } \\
\hline \multicolumn{4}{|c|}{$\begin{array}{l}\text { Tank Characterization Report for Single-Shel1 Tank 241-T-109, } \\
\text { WHC-SD-WM-ER-559. Rev. } 0\end{array}$} & \multicolumn{2}{|c|}{ ECN No. $\quad$ N/A } \\
\hline Name & MSIN & $\begin{array}{c}\text { Text } \\
\text { With All } \\
\text { Attach. }\end{array}$ & Text Only & $\begin{array}{l}\text { Attach./ } \\
\text { Appendix } \\
\text { Only }\end{array}$ & $\begin{array}{l}\text { EDT/ECN } \\
\text { Only }\end{array}$ \\
\hline
\end{tabular}

OFFSITE

Sandia National Laboratory

P.0. Box 5800

MS-0744. Dept. 6404

Albuquerque, NM 87815

D. Powers

Nuclear Consulting Services Inc.

P. 0. Box 29151

Columbus, OH 43229-01051

J. L. Kovach

$x$

Chemical Reaction Sub-TAP

P. 0. Box 271

Lindsborg, KS 67456

B. C. Hudson

$x$

Tank Characterization Panel

Senior Technical Consultant

Contech

7309 Indian School Road

Albuquerque, NM 87110

J. Arvisu

$x$

U. S. Department of Enerqy - Headquarters

Office of Environmental Restoration and Waste Management EM-563

12800 Middlebrook Road

Germantown. MD 20874

J. A. Poppitti X

Jacobs Engineering Group $\quad$ B5-36 $\quad X$ 


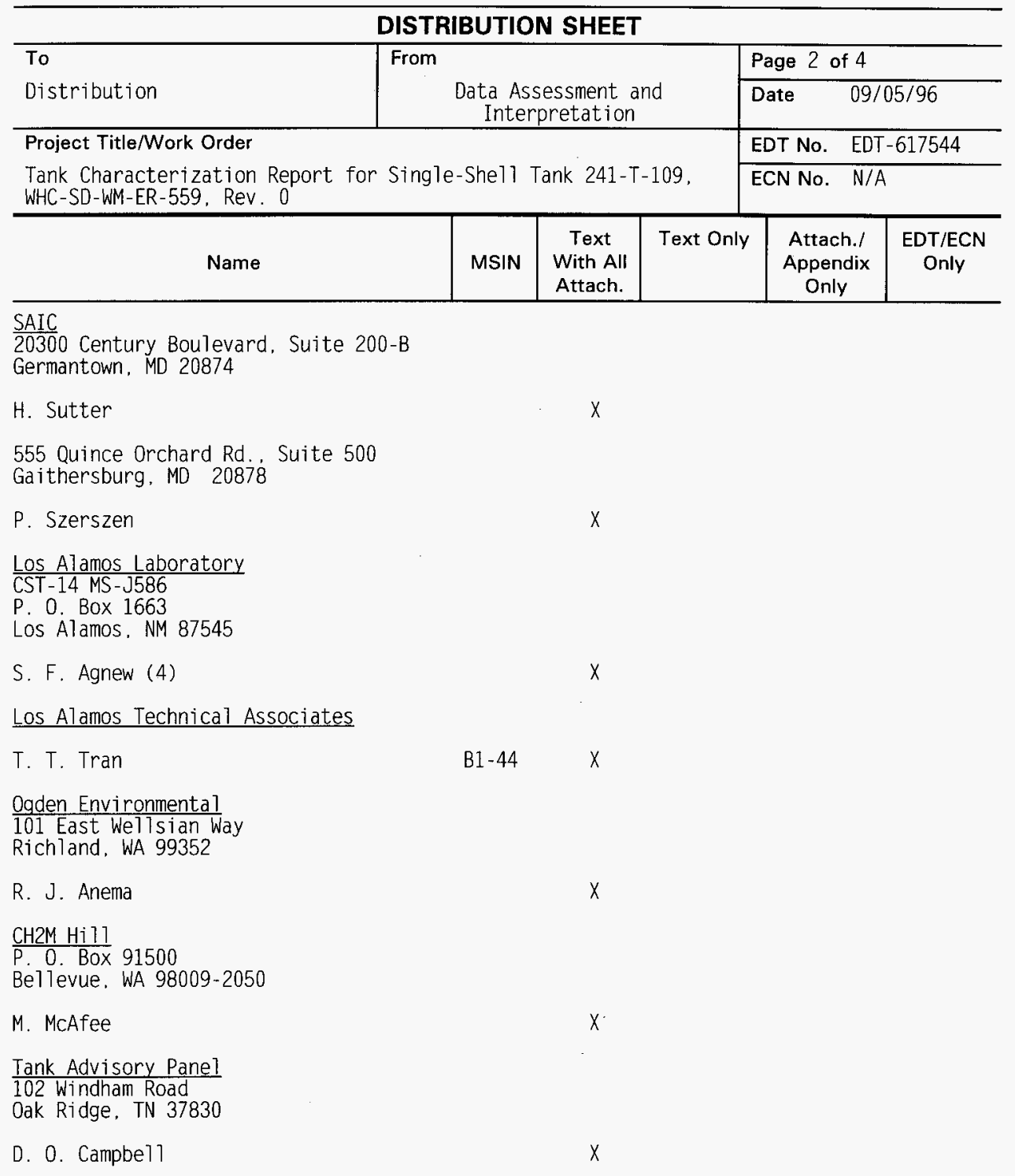




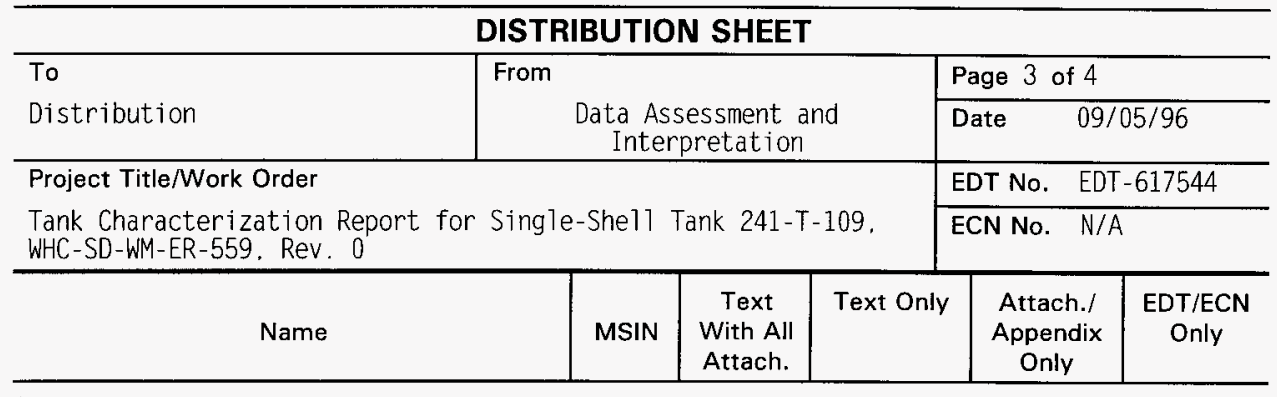

ONSITE

Department of Energy - Richland Operations
J. F. Thompson
$57-54$
$57-54$
S7 -54
$X$
$X$
$X$
N. W. Wi 71 is

ICF-Kaiser Hanford Company
R. L. Newell
S3-09
$X$

Pacific Northwest Laboratory
N. G. Colton
$\mathrm{K} 3-75$
K7-28
J. R. Gormsen
$\mathrm{K} 5-12$
S. A. Hartley
K7 -94
J. G. $\mathrm{Hi} 11$
G. J. Lumetta
P7 -25
K9-81
A. F. Noonan

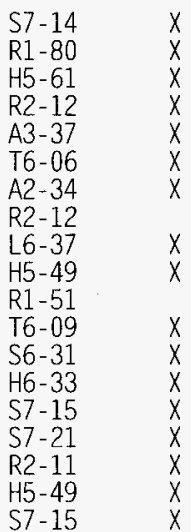

Eberlein

D. B. Engelman

J. S. Garfield

$x$

J. D. Guberski

D. L. Herting

D. C. Hetzer

G. Jansen

G. D. Johnson

T. J. Kelley

N. W. Kirch

M. J. Kupfer

J. E. Meacham

S7-15 


\section{DISTRIBUTION SHEET}

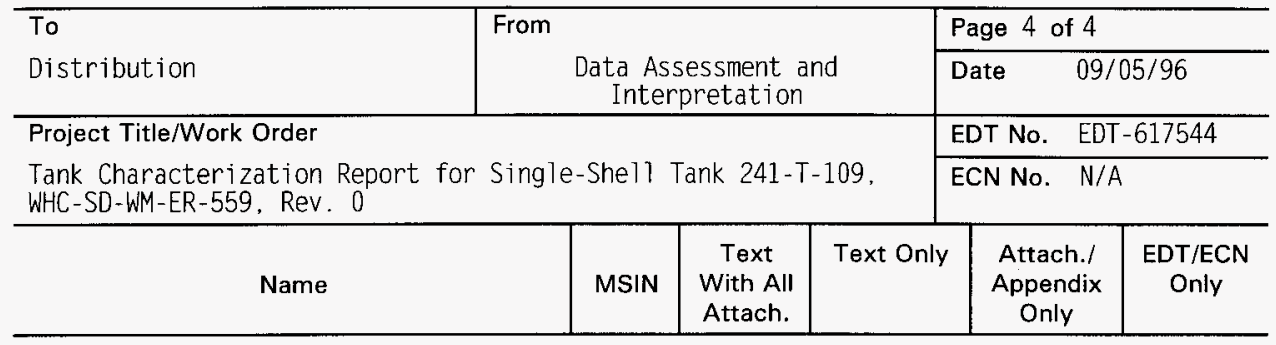

Westinghouse Hanford Company continued
W. C. Miller
C. T. Narquis
D. E. Place
D. A. Reynolds
L. M. Sasaki (3)
L. W. Shelton, Jr.
B. C. Simpson
G. L. Troyer
L. R. Webb
K. A. White Central Files
EDMC
ERC (Environmental Resource Center)
TCRC (10)

$\begin{array}{ll}\text { R1 }-56 & x \\ \text { T6-16 } & x \\ \text { H5-27 } & x \\ \text { R2 }-11 & x \\ \text { R2 }-12 & x \\ \text { H5 }-49 & x \\ \text { R2-12 } & x \\ \text { T6-50 } & x \\ \text { T6-06 } & x \\ \text { S5-13 } & x \\ \text { A3 }-88 & x \\ \text { H6-08 } & x \\ \text { R1 }-51 & x \\ \text { R2 }-12 & x\end{array}$

